\title{
INCORPORAÇÃO DOS TRATADOS INTERNACIONAIS DE DIREITOS HuMANOS AO DIREITO INTERNO BRASILEIRO E SUA POSIÇÃO HIERÁRQUICA NO PLANO DAS FONTES NORMATIVAS
}

\author{
DisSERTAÇÃO DE MESTRADO \\ Orientador: Professor Associado Elival Da Silva Ramos
}

UNIVERSIDADE DE SÃo PAULO

FACULDADE DE DiREITO

2008 
Marco Antonio CorrêA Monteiro

INCORPORAÇÃO DOS TRATADOS INTERNACIONAIS DE DIREITOS HUMANOS AO DIREITO INTERNO BRASILEIRO E SUA POSIÇÃO HIERÁRQUICA NO PLANO DAS FONTES NORMATIVAS

Dissertação apresentada à Faculdade de Direito da Universidade de São Paulo, como requisito parcial para obtenção do título de Mestre em Direito do Estado (Direito Constitucional), sob orientação do Professor Associado Elival da Silva Ramos.

Universidade de São Paulo

São Paulo

2008 
A meus pais, Maura Julia e José Carlos, mais uma vez e sempre.

A Fabiana, que muito me tem apoiado em meus primeiros passos profissionais. 


\section{AgradecimenTOS.}

Um trabalho acadêmico não se elabora sozinho e nem de uma hora para outra. Do surgimento de uma idéia à revisão final, muitas pessoas deixam nele a sua contribuição.

A vontade de cursar o Pós-Graduação nas Arcadas surgiu logo no primeiro semestre de 2001 quando, em razão do exercício da representação de turma, para resolver assuntos de interesse da sala, tive que freqüentar algumas aulas do saudoso Professor Marcelo Fortes Barbosa. Foi ele o primeiro Professor com quem conversei sobre o curso de Pós-Graduação e sobre a carreira acadêmica.

Em 2 de agosto desse mesmo ano, comecei o meu estágio no escritório do Professor Manoel Gonçalves Ferreira Filho. A partir desse dia, tive aulas praticamente diárias de direito constitucional, o que me incentivou cada vez mais a aprofundar os estudos na matéria. Foi o Professor Manoel Gonçalves orientador em minha Tese de Láurea, trabalho que me abriu perspectivas de pesquisa no tema que hoje desenvolvo em minha dissertação. É incalculável a sua contribuição em meu aprendizado jurídico, motivo por que lhe serei sempre grato.

Já no primeiro ano de meu curso de direito fui aluno da Professora Monica Herman Salem Caggiano, a quem muito devo agradecer. Também em 2001, participei de grupo de pesquisa sobre legislação de direito político, coordenado pela Professora Monica. Foi em razão dessa atividade acadêmica que fui, pela primeira vez, à Universidade Presbiteriana Mackenzie, onde hoje leciono direito constitucional. Agradeço, assim, à Professora Monica a oportunidade acadêmica que me foi confiada.

À Professora Fernanda Dias Menezes de Almeida não me caso de agradecer. Desde antes da elaboração de minha Tese de Láurea, que a Professora, com certeza, leu mais vezes que eu próprio, mostrou-se ela sempre atenciosa e paciente, não existindo momento em que a Professora Fernanda não estava disposta a atender-me de maneira acolhedora. Ainda não há palavras que sejam suficientes para expressar o quanto lhe sou grato.

Agradeço também ao Professor Cláudio Lembo, de quem tenho a honra de ser assistente na Faculdade de Direito da Universidade Presbiteriana Mackenzie. Em suas aulas e em nossas discussões, sempre busquei subsídios para a pesquisa e para a elaboração deste trabalho. 
Tenho muitas razões para agradecer ao Professor Elival da Silva Ramos. Esta dissertação, indubitavelmente, não seria a mesma não fossem suas constantes orientações. Foram inúmeras conversas, reuniões, debates, enfim, verdadeiras aulas, das quais tentei extrair o máximo possível de informações. Reafirmo, agora com mais motivos, o que escrevi nos agradecimentos de meu trabalho de conclusão de curso de Especialização: é, de fato, um privilégio ser orientado pelo Professor Elival, privilégio esse que continuo tentando retribuir, diariamente, com muito estudo e dedicação.

Não poderia deixar também de agradecer a pessoas que tive a alegria de conhecer ao longo desses últimos anos. São pessoas que conheci no curso de Graduação, de Mestrado: Alves, Blasi, Camila, Fernanda, Octavio, Passamani, Velloso, George, Francisco, Fernando, Gabriel, Thiago, Carolina. E, mais recentemente, aos colegas da Defensoria Pública do Estado, aos quais agradeço em nome de nossa Coordenadora, Elaine.

Por fim, a Deus, que me permitiu o dom da Vida e a convivência com todas as pessoas que a fazem ter sentido. 


\section{SUMÁRIO.}

Introdução, 8.

1. Fundamentos da incorporação dos tratados internacionais de direitos humanos ao direito interno, 12.

1.1. Os modelos de relações entre direito interno e direito internacional, 12.

1.1.1. O modelo dualista, 12.

1.1.1.1. Fundamento teórico do modelo dualista, 13.

1.1.1.2. Conseqüências da adoção do modelo dualista, 14.

1.1.2. O modelo monista, 20.

1.1.2.1. Fundamento teórico do modelo monista, 20.

1.1.2.2. Conseqüências da adoção do modelo monista, 23.

1.2. Os fundamentos teóricos dos modelos e suas conseqüências na atualidade, 27.

1.2.1. Soberania estatal: incompatibilidade com o modelo monista, 27.

1.2.2. A existência de fontes jurídicas diversas como decorrência da soberania estatal, 30 .

1.2.3. A vigência do modelo dualista: análise crítica de suas conseqüências, 33.

1.2.3.1. O conteúdo diverso das normas de direito interno e de direito internacional: superação de uma das conseqüências do modelo dualista, 34 .

1.2.3.2. A possibilidade de um ato normativo de direito internacional ser aplicado no direito interno, 36.

1.2.3.3. Conflitos entre normas do direito interno e normas do direito internacional e os critérios para a sua resolução, 40.

1.2.3.4. A responsabilidade internacional do Estado, 46.

2. Análise da incorporação e da posição hierárquica dos tratados internacionais de direitos humanos no direito estrangeiro, 48.

2.1. Espanha, 48.

2.2. França, 51. 
2.3. Portugal, 54.

2.4. Argentina, 57.

2.5. Paraguai, 64.

2.6. Uruguai, 67.

3. Os princípios adotados pela República Federativa do Brasil em suas relações internacionais, 70 .

3.1. Fundamentos da República Federativa do Brasil, 70.

3.2. Objetivos fundamentais da República Federativa do Brasil 75.

3.3. Princípios regentes da República Federativa do Brasil em suas relações internacionais, 76.

3.3.1. Princípios nacionalistas: a independência nacional, a autodeterminação dos povos, a não-intervenção e a igualdade entre os Estados, 77.

3.3.2. Princípios internacionalistas: a prevalência dos direitos humanos e o repúdio ao terrorismo e ao racismo, 79.

3.3.3. Princípios pacifistas: defesa da paz, solução pacífica dos conflitos e concessão de asilo político, 81.

3.3.4. Princípios de orientação comunitária: a cooperação entre os povos para o progresso da humanidade e a busca da integração econômica, política, social e cultural dos povos da América Latina, visando à formação de uma comunidade latino-americana de nações, 84.

3.4. Compatibilidade entre os fundamentos, os objetivos e os princípios regentes da República Federativa do Brasil em suas relações internacionais, 85.

4. Procedimentos de celebração e de incorporação dos tratados internacionais de direitos humanos ao direito interno brasileiro, 87.

4.1. Distinção entre procedimento de celebração e procedimento de incorporação, 87.

4.2. Procedimento de celebração dos tratados internacionais de direitos humanos pela República Federativa do Brasil, 88.

4.2.1. Negociação e assinatura do tratado pelo Poder Executivo, 88.

4.2.2. Envio de Mensagem ao Congresso Nacional: indicação do tratado internacional como de direitos humanos, 92. 
4.2.3. Aprovação pelo Congresso Nacional: participação do Poder Legislativo, 93.

4.2.4. Ratificação do tratado internacional pelo Poder Executivo, 100.

4.2.5. Adesão ao tratado internacional pela República Federativa do Brasil, 102.

4.3. Incorporação dos tratados internacionais de direitos humanos ao direito interno brasileiro, 103.

4.3.1. Desnecessidade de promulgação e publicação dos tratados internacionais de direitos humanos por meio de decreto do Executivo, 103.

4.4. Entrada em vigor na ordem jurídica internacional e na ordem jurídica interna, 111.

4.5. Denúncia dos tratados internacionais de direitos humanos pela República Federativa do Brasil, 113.

5. Posição hierárquica dos tratados internacionais de direitos humanos no plano das fontes normativas, 117.

5.1. Equivalência dos tratados internacionais de direitos humanos às emendas constitucionais (artigo 50, §3º , da Constituição), 120.

5.2. Alcance do $\S 2^{\circ}$ do artigo $5^{\circ}$ da Constituição, 124.

5.3. Posição hierárquica dos tratados internacionais de direitos humanos incorporados antes da Emenda Constitucional n 45/04, 125.

5.4. A idéia de bloco de constitucionalidade no direito brasileiro e a organicidade da Constituição de 1988, 128.

Conclusão, 133.

Referências, 136. 


\section{INTRODUÇÃO.}

As relações entre direito internacional e direito interno tomam grande parte da atenção dos juristas na atualidade. As relações internacionais cada vez mais se intensificam, acarretando a aplicação diuturna de atos normativos não produzidos pelos Estados nacionais, no exercício incontrastável de sua soberania, para a resolução de questões antes tidas como de exclusividade de seu direito interno.

Os Estados deixaram de ser os únicos atores do cenário internacional e passaram a dividir esse papel com outras "realidades propriamente mundiais" ${ }^{1}$, tal qual os grandes grupos econômicos. Surgem meios mais rápidos e eficazes de resolução de conflitos, sobretudo de conteúdo econômico. Surge um corpo de normas que "não compete com a lei do Estado, nem constitui um direito supranacional que derroga o direito nacional, mas é um direito adotado, sobretudo, na arbitragem comercial internacional ou outra forma de resolução de controvérsias, ad latere do sistema estatal. Este o sentido e a amplitude da chamada lex mercatoria”, nas palavras de José Carlos de Magalhães².

A atual complexidade das relações internacionais é inegável.

Todavia, apesar da constatação de grandes alterações nesse contexto, o poder soberano estatal ainda se faz presente. O Estado continua sendo o principal centro irradiador das normas internacionais e não podem estas ser aplicadas em seu âmbito territorial interno sem a sua chancela. Ademais, se, por um lado, houve intenso desenvolvimento na produção normativa de cunho econômico à revelia do poder soberano estatal, por outro, a produção e a garantia de aplicação das normas de direitos humanos ainda dependem predominantemente da atuação dos Estados nacionais.

Nessa seara, tema relevante é a incorporação dos tratados internacionais de direitos humanos ao direito brasileiro, bem como a sua posição hierárquica no plano das fontes normativas. Esse tema, que nunca deixou de preocupar constitucionalistas, internacionalistas e até tributaristas ${ }^{3}$ nacionais, retomou seu vigor com a inserção do $\S$ $3^{\circ}$ ao artigo $5^{\circ}$ da Constituição de 1988, que prescreve que "os tratados e convenções internacionais sobre direitos humanos que forem aprovados, em cada Casa do

\footnotetext{
${ }^{1}$ Cf. Octavio Ianni, Teorias da globalização, p.30.

${ }^{2}$ Lex mercatoria, p.43.

3 Estes, em razão do artigo 98 do Código Tributário Nacional, que prescreve que "os tratados e convenções internacionais revogam ou modificam a legislação tributária interna, e serão observados pela que sobrevenha”.
} 
Congresso Nacional, em dois turnos, por três quintos dos votos dos respectivos membros, serão equivalentes às emendas constitucionais”.

A análise dessas relações internacionais deve passar, invariavelmente, pelo questionamento da própria existência de ordens jurídicas estatais independentes, em contraposição a uma ordem jurídica internacional, ou da existência unicamente de uma ordem jurídica global. Trata-se do tradicional debate entre monismo e dualismo, que será analisado com base nos modelos apresentados por Triepel, Anzilotti e Kelsen, levando-se em conta o contexto histórico em que foram elaborados.

Da leitura dos textos, procura-se distinguir fundamentos teóricos e conseqüências da adoção de cada um dos modelos. Identificados ambos, fundamentos e conseqüências, passa-se à análise dos modelos monista e dualista na atualidade, excluindo-se a aplicação daquele, pois incompatível com o exercício do poder soberano estatal, e avaliando-se a vigência do segundo, com enfoque nas conseqüências de sua adoção.

Em seguida, no segundo capítulo, faz-se necessário trazer ao trabalho a abordagem da incorporação dos tratados internacionais, em especial os de direitos humanos, e de sua posição hierárquica nos ordenamentos jurídicos espanhol, francês, português, argentino, paraguaio e uruguaio. Destacam-se, nesse tópico, dispositivos constitucionais tais como os contidos no artigo 96, 1 e 2, da Constituição espanhola de 1978, que espelham aspectos tratados no primeiro capítulo deste trabalho, e o esculpido pelo artigo 75, 22, do texto constitucional argentino, que inspirou diretamente o legislador brasileiro na reforma de 2004.

Não se concebe o estudo da Ciência Jurídica nos dias que correm sem a análise da maneira pela qual outros Estados tratam o assunto, em especial em seu texto constitucional. Essa necessidade faz-se ainda mais presente em face do tema proposto, que se encontra igualmente nos domínios do direito internacional e dos direitos humanos. Optou-se, dessa forma, por abordar a ordem jurídica dos demais Estados componentes do Mercosul, Argentina, Paraguai e Uruguai, bem como três outros Estados, Portugal, Espanha e França, por exercerem influência direta na doutrina, jurisprudência e produção normativa nacional.

Partindo-se do direito estrangeiro para o texto constitucional brasileiro, são discutidos, no capítulo terceiro, os fundamentos, os objetivos e os princípios regentes da República Federativa do Brasil em suas relações internacionais. Os princípios constitucionais, previstos no artigo $4^{\circ}$ da Constituição, são divididos, para efeitos 
didáticos, em nacionalistas, internacionalistas, pacifistas e de orientação comunitária, mas interpretados de maneira a harmonizá-los.

É tão-somente após uma interpretação harmônica dos princípios constitucionais que regem a República Federativa do Brasil em suas relações internacionais que se pode prosseguir nos estudos das demais normas constitucionais sobre a incorporação e a posição hierárquica dos tratados de direitos humanos.

Nesses três primeiros capítulos, assim, são apresentados os pressupostos a partir dos quais são analisados o procedimento de celebração e de incorporação dos tratados internacionais de direitos humanos ao direito brasileiro e a posição hierárquica ocupada por esses tratados no plano das fontes normativas. O objeto central do trabalho encontra-se, pois, dividido nos capítulos quarto e quinto.

O quarto capítulo inicia-se com a distinção entre procedimento de celebração e procedimento de incorporação de tratados internacionais. Após, com relação ao procedimento de celebração, são analisados a negociação e a assinatura do tratado pelo Poder Executivo, o envio de mensagem ao Congresso Nacional, a deliberação pelo Legislativo e a sua ratificação, também pelo Executivo. A desnecessidade de promulgação e de publicação, por meio de decreto executivo, dos tratados internacionais de direitos humanos, tema referente ao procedimento de incorporação, e a possibilidade de sua denúncia também são trazidas nesse capítulo.

Em suma, desenvolvem-se, nesse ponto, as repercussões procedimentais da introdução do novel dispositivo constitucional. Poder-se-á notar que em muitos aspectos não houve alteração com relação ao que se desenvolvia anteriormente. A questão de fundo, porém, que permeia todo o capítulo é a extensão da aplicação das normas que regulam o procedimento de elaboração de emendas constitucionais, essencialmente em razão da expressão esculpida no $\S 3^{\circ}$ do artigo $5^{\circ}$ da Constituição. Na intenção de atribuir posição hierárquica constitucional aos tratados internacionais de direitos humanos, o revisor constituinte não se utilizou de expressão clara, que determinasse esse atributo aos atos normativos internacionais de direitos humanos, mas prescreveu que esses tratados, aprovados pelo procedimento nele previsto, "serão equivalentes às emendas constitucionais”, o que traz, evidentemente, conseqüências de ordem processual, e não meramente de ordem material.

Por fim, no último capítulo, com base no artigo $5^{\circ}$, § $3^{\circ}$, da Constituição, é analisada a posição hierárquica dos tratados internacionais de direitos humanos no direito brasileiro, bem como algumas de suas decorrências na interpretação do artigo $5^{\circ}$, 
$\S 2^{\circ}$, do texto constitucional, na posição hierárquica dos tratados internacionais de direitos humanos incorporados em momento anterior à emenda constitucional $n^{\circ} 45 / 04$, na existência de um bloco de constitucionalidade no direito brasileiro e na organicidade da Constituição da República Federativa do Brasil de 1988.

Tentou-se, em suma, no presente trabalho, elaborar uma visão sistemática do assunto, partindo-se de seus fundamentos, no que tange às relações entre direito interno e direito internacional, buscando-se o tratamento da matéria em outras ordens jurídicas, para, consolidados os princípios do texto constitucional de 1988, concluir-se com a análise dos procedimentos de celebração e de incorporação dos tratados internacionais de direitos humanos ao direito brasileiro e de sua posição hierárquica no plano das fontes normativas. 


\section{FUNDAMENTOS DA INCORPORAÇÃO DOS TRATADOS} INTERNACIONAIS DE DIREITOS HUMANOS AO DIREITO INTERNO.

A análise da incorporação dos tratados internacionais de direitos humanos ao direito interno brasileiro, bem como a sua posição hierárquica nesse mesmo ordenamento, tem como pressuposto necessário o estudo preliminar dos fundamentos da incorporação desses tratados internacionais, concebidos no seio do direito internacional, pelos diversos ordenamentos jurídicos internos.

Em poucas palavras, faz-se necessário o estudo das relações entre os diversos ordenamentos jurídicos nacionais existentes e o direito internacional ${ }^{4}$.

Essas relações têm sido reduzidas pela doutrina a dois grandes modelos, o dualista e o monista, idealizados inicialmente por Heinrich Triepel ${ }^{5}$, Dionisio Anzilotti ${ }^{6}$ e Hans Kelsen ${ }^{7}$, sobre os quais dissertaremos nos tópicos que se seguem, para, em seguida, questionar a permanência na atualidade de seus fundamentos.

Não se trata essa análise de mera discussão teórica, nem está a discussão superada. Trata-se, sim, de fundamento doutrinário que, em última análise, determina a posição hierárquica dos tratados internacionais, dentre os quais os de direitos humanos, no plano das fontes normativas. Tanto é assim que, quase invariavelmente, os juristas que tratam do tema da incorporação dos tratados internacionais e de sua posição hierárquica partem da análise da dicotomia “dualismo-monismo”.

Dada a importância apontada, passa-se, em um primeiro momento, à apresentação de ambos os modelos de relações entre os mais diversos direitos internos e o direito internacional, para, a seguir, levando-se em consideração o momento jurídico atual, verificar a pertinência desses modelos, questionando-se os seus fundamentos.

1.1. Os modelos de relações entre direito interno e direito internacional.

1.1.1. O modelo dualista.

\footnotetext{
${ }^{4}$ Os tratados internacionais são considerados uma das fontes do direito internacional, mas, para que se discuta a sua incorporação pelos Estados, faz-se necessária a discussão das relações entre esses ordenamentos estatais e o direito internacional como um todo (direito internacional geral e direito internacional convencional).

${ }^{5}$ Les rapports entre le droit interne et le droit international.

${ }^{6}$ Corso di Diritto Internazionale.

7 Les rapports de système entre le droit interne et le droit internacional public e Teoria pura do direito.
} 


\subsubsection{Fundamento teórico do modelo dualista.}

Concebido inicialmente por Heinrich Triepel, o modelo dualista parte de um fundamento para identificar as relações entre o direito interno e o direito internacional ${ }^{8}$ : as normas de direito interno e de direito internacional decorrem de fontes jurídicas distintas.

Fontes do direito, conforme conceitua Norberto Bobbio, são "aqueles fatos ou aqueles atos aos quais um determinado ordenamento jurídico atribui a competência ou a capacidade de produzir normas jurídicas” ${ }^{9}$. Não se trata, pois, de fontes jurídicas imediatas, ou formais, instrumentos por meio dos quais são introduzidas, em determinado ordenamento, normas jurídicas. São exemplos dessas a lei, o tratado, a medida provisória, entre outros atos normativos. Trata-se, sim, de fontes jurídicas mediatas, ou materiais, fundamento último de todo o ordenamento jurídico, inclusive dos atos normativos introdutores de normas.

Segundo Triepel, “uma regra jurídica é o conteúdo de uma vontade superior às vontades individuais, manifestadas em vista de limitar as esferas de vontades humanas que lhe são submetidas” e, assim, fonte jurídica é “a vontade da qual a regra jurídica deriva” ${ }^{10}$. Nesse sentido, no direito interno, fonte jurídica é a vontade do próprio Estado, enquanto que, no direito internacional, fonte de direito é a vontade comum, nascida da união das vontades dos Estados ${ }^{11}$.

Não é diverso o entendimento de Dionisio Anzilotti, para quem "as normas de conduta constituídas mediante acordos entre Estados - normas jurídicas internacionais são notadamente diversas das normas jurídicas próprias das organizações estatais normas jurídicas internas - como diversas são as características da sociedade de Estados daquelas próprias das agregações humanas organizadas sob um poder de império”12.

\footnotetext{
${ }^{8}$ Importante anotar que, quando se utiliza unicamente a denominação direito internacional, é ao direito internacional público que se refere, não ao direito internacional privado, que, na verdade, é direito interno, e não internacional. Cf. Oscar Tenório, Direito internacional privado, p.10, Jacob Dolinger, Direito internacional privado, p.6, Beat Walter Rechsteiner, Direito internacional privado, p.6.

Na ordem jurídica brasileira, o direito internacional privado encontra-se disciplinado, principalmente, pelo decreto-lei $\mathrm{n}^{\circ} 4.657$, de 4 de setembro de 1942, a equivocadamente denominada Lei de Introdução ao Código Civil, pois dispõe de normas de aplicação das normas em geral, não somente as do Código Civil; trata-se, sim, de normas de teoria geral do direito.

${ }^{9}$ O positivismo, p.161.

${ }^{10}$ Les rapports, p.82.

${ }^{11}$ Les rapports, p.82-83. Admite Triepel a existência de um direito internacional costumeiro, criado por meio de uma declaração "tácita" desse direito por parte dos Estados em conjunto, mas nunca à revelia dessa manifestação de vontade.

${ }^{12}$ Corso, p.27.
} 
Afirma-se, dessa forma, que direito internacional e direito interno são diversos, pois distintas são as fontes jurídicas das quais decorrem suas normas.

Entre os brasileiros, aderiram a esse modelo, por exemplo, Amílcar de Castro ${ }^{13}$ e Cunha Peixoto $^{14}$, Ministro do Supremo Tribunal Federal.

Amílcar de Castro sustenta que o direito internacional obriga o governo na ordem externa, explana relações entre governantes, de maneira horizontal, entre pessoas de maneira coordenada; já o direito interno obriga o povo na ordem interna, explana relações do governo com seus súditos, de maneira vertical, entre subordinante e subordinado ${ }^{15}$.

Para Cunha Peixoto, que se utiliza das lições de Amílcar de Castro para expor seu entendimento, tratado não é lei, é ato internacional. O tratado internacional disciplina relações entre governantes, relações horizontais, entre pessoas coordenadas, enquanto que a lei disciplina relações do governo com seus súditos. O tratado é fonte no direito internacional, só obriga o governo “para fora”, mas não é fonte de direito interno, não obriga os particulares individualmente considerados, em suas palavras, não obriga "para dentro" do Estado ${ }^{16}$.

\subsubsection{Conseqüências da adoção do modelo dualista.}

Conseqüências da adoção desse modelo, apontadas por Triepel ${ }^{17}$, são (1) o direito internacional e o direito interno têm normas com objetos distintos, pois regem relações sociais igualmente distintas, (2) a impossibilidade de um ato normativo de

\footnotetext{
${ }^{13}$ Direito internacional privado, p.123-124.

${ }^{14}$ O Ministro Cunha Peixoto participou do conhecido julgamento do recurso extraordinário no 80.004/77, publicado na RTJ 33/809. A discussão do acórdão se dá em torno da validade do decreto-lei no ${ }^{\circ}$ 427/1969, condição para a resolução da persistência, ou não, da responsabilidade do avalista, exigível por ação ordinária de cobrança. O decreto-lei acrescentou novo requisito de validade para as notas promissórias e letras de câmbio, qual seja, o registro do título, dentro do prazo de decadência, na repartição competente definida pelo Ministério da Fazenda, cuja omissão acarretaria a nulidade do título. Esse novo requisito, por contrariar a Convenção de Genebra sobre títulos de crédito, não no sentido de dispor de forma contrária, mas de exigir requisito que a Convenção não exigia, seria inválido, se admitida a superioridade hierárquica de tratado sobre lei interna ordinária, ainda que posterior.

${ }^{15}$ Direito internacional privado, p.124.

${ }^{16}$ Recurso Extraordinário no ${ }^{\circ} 80.004 / 77$, p.818.

${ }^{17}$ Les rapports, p.83-84. Vicente Marotta Rangel, Os conflitos entre o direito interno, p.31-32, aponta expressamente conseqüências da separação das duas ordens, interna e internacional: "validade de normas internas contrárias ao Direito das gentes; impossibilidade de que uma ordem jurídica possa determinar a validade das normas de outra ordem; inadmissibilidade da norma internacional no Direito interno; necessidade de transformação da norma internacional para integrar-se no Direito interno; inocorrência de primazia de uma ordem sobre outra, por se constituírem 'dois círculos que estão em contacto íntimo mas que não se sobrepõe jamais”; seguiremos, contudo, as conseqüências extraídas do texto de Triepel, das quais decorrerão as análises desenvolvidas ao longo do trabalho.
} 
direito internacional ser aplicado no direito interno e de um ato normativo de direito interno ser aplicado no direito internacional, (3) a impossibilidade de haver conflito entre normas de direito internacional e normas de direito interno e (4) a responsabilidade internacional do Estado, no caso de o direito interno dispor de maneira contrária ao direito internacional assumido pelo Estado.

Pela primeira conseqüência, afirma-se que o direito internacional e o direito interno têm normas com objetos distintos, pois regem relações sociais igualmente distintas.

O direito interno, segundo Triepel, é aquele estabelecido no interior de uma comunidade nacional, pelo Estado, para reger as relações entre sujeitos a ele submetidos em razão de sua soberania ${ }^{18}$.

Esses sujeitos são os indivíduos, nacionais ou estrangeiros, sendo as regras jurídicas de duas espécies, as de direito privado, que regem as relações entre os indivíduos, e as de direito público, que regem as relações entre estes e o próprio Estado. Pode ainda o Estado editar normas que rejam as relações entre esses mesmos indivíduos e os Estados estrangeiros ou entre ele próprio (Estado) e outro Estado estrangeiro; nesse caso, contudo, o Estado estrangeiro comportar-se-ia como um "simples particular", razão pela qual a natureza da norma a reger esta relação é de direito interno, e não de direito internacional. Conclui Triepel que "em todos os casos é certo que essas leis regem as relações entre os sujeitos que o legislador acreditou poder considerar como lhe estando submetidos”19

Ainda segundo o mesmo autor, o direito internacional rege as relações entre Estados e somente entre Estados “perfeitamente iguais”. Os indivíduos, por sua vez, não são sujeitos do direito internacional; estes somente podem ser compreendidos como objeto de direitos e deveres internacionais ${ }^{20}$.

Nesse mesmo fundamento, baseia-se Dionisio Anzilotti para afirmar a prevalência do modelo dualista nas relações entre o direito interno e o direito internacional. Para Anzilotti, “do princípio que toda norma é jurídica apenas no ordenamento do qual faz parte, deriva a clara separação entre direito internacional e direito interno enquanto resguarda a obrigatoriedade das respectivas normas: as normas

\footnotetext{
${ }^{18}$ Les rapports, p.80.

${ }^{19}$ Les rapports, p.80.

${ }^{20}$ Les rapports, p.81. Na página seguinte, Triepel comenta uma possibilidade, em uma "evolução futura”, em "um direito internacional absolutamente novo", de alguns grupos do interior dos Estados serem reconhecidos como sujeitos do direito internacional.
} 
internacionais são eficazes somente nas relações entre os sujeitos do ordenamento internacional; as normas internas no ordenamento estatal ao qual pertencem”21.

Com relação à segunda das conseqüências, afirma Triepel que "um tratado de extradição obriga o Estado a remeter criminosos; a lei de execução obriga as autoridades policiais a apoderar-se de um criminoso fugitivo e as autoriza a remeter o malfeitor ao estrangeiro. Certamente a lei interna dependerá por vezes de uma regra de direito internacional; mas ela colocará em aplicação uma regra jurídica cujo conteúdo não é o mesmo. Não se trata, naquela "apropriação”, de uma recepção, mas de uma reprodução sob uma forma modificada"22.

Continua o internacionalista, para concluir, sustentado que "um tratado internacional nunca é, então, por si um meio de criação do direito interno. Ele pode somente constituir um convite a criar esse direito, mas a formação do direito repousa sempre no Estado, sob um ato particular de vontade do Estado, distinto da sua participação no desenvolvimento jurídico internacional. É um erro dizer que a publicação de um tratado internacional pelo governo de um Estado, em vista de fazê-lo observar pelas autoridades e pelos sujeitos, tem por efeito dar ao tratado sua 'validade interna'. Porque o tratado internacional continua tratado internacional mesmo quando ele é publicado em um jornal oficial ou de outra maneira, e somente se pode falar de uma validade internacional dos tratados. Ainda que o tratado seja publicado pelo Estado, ele somente é obrigatório para o próprio Estado e é ainda inexato dizer que a publicação do tratado lhe torna obrigatório aos sujeitos do Estado; não é o tratado, é a norma estatal, criada talvez por meio da simples publicação do tratado, que é obrigatória aos sujeitos do Estado. Deve-se, então, dizer: uma fonte de direito internacional é tão pouco capaz de criar, por ela mesma, uma regra de direito interno quanto uma fonte de direito interno não está em condições de produzir, por ela mesma, o direito internacional”23.

Não é distinto o entendimento de Dionisio Anzilotti, vez que, por se diferenciarem os sujeitos aos quais se dirigem os atos normativos do direito internacional e do direito interno, não poderia um vir a tornar-se parte do outro. Não é por outro motivo que o autor critica o entendimento da jurisprudência inglesa e norteamericana de que "o direito internacional é parte do direito da terra" - "international

\footnotetext{
${ }^{21}$ Corso, p.32.

${ }^{22}$ Les rapports, p.84.

${ }^{23}$ Les rapports, p.84.
} 
Law is a part of the Law of the land”24, segundo o qual o tratado internacional seria, ao mesmo tempo, direito internacional e direito interno.

Nesse mesmo sentido, sustenta o Ministro Cunha Peixoto que, no direito brasileiro, o tratado não é transformado em direito positivo; o direito internacional rege as relações entre Estados, enquanto o direito interno rege relações outras, não podendo um transformar-se no outro, de acordo com os interesses do Congresso, dadas as suas naturezas distintas ${ }^{25}$.

Por sua vez, Amílcar de Castro afirma que o tratado internacional "só opera na ordem internacional, que é independente da nacional, e entre ordens independentes não podem as normas de uma provir da outra” 26 .

Em razão do exposto, o direito internacional não pode ser aplicado diretamente pelos operadores do direito interno, nem o direito interno pode ser aplicado diretamente pelos operadores do direito internacional ${ }^{27}$. O Estado, para cumprir uma obrigação internacionalmente assumida, deve editar um ato normativo interno, derivado, assim, de sua fonte jurídica, que reproduza o conteúdo do direito internacional a ser cumprido. Dessa forma, não é o direito internacional aplicado no âmbito interno, mas, sim, o próprio direito interno, mas de conteúdo idêntico ao do direito internacional.

Disso decorre a distinção apontada por Triepel $^{28}$ e Anzilotti ${ }^{29}$ entre "direito interno internacionalmente relevante” e "direito interno internacionalmente irrelevante”, que serve, para os fins deste trabalho, unicamente para ilustrar a solução proposta pelos autores para o cumprimento dos compromissos internacionalmente assumidos.

\footnotetext{
${ }^{24}$ Corso, p.35-36. Sobre esse dispositivo, afirma Triepel (Les rapports, p.89-91) que, na verdade, os tratados não são aplicados pelos Tribunais como se direito interno fossem; os tratados somente são aplicados, na Inglaterra, após a adoção de uma lei formal pelo Parlamento ou, nos Estados Unidos, após a sua proclamação formal pelo Presidente da República e seria essa intervenção do poder estatal, puramente declarativa, que, reproduzindo o seu conteúdo, os tornaria aplicáveis pelos Tribunais.

${ }^{25}$ Recurso Extraordinário n.80.004/77, p.822.

${ }^{26}$ Direito internacional privado, p.123.

${ }^{27}$ Mesmo Tripel admite uma certa mitigação a esta regra geral. Haveria a aplicação do direito internacional no âmbito interno nos casos de transferência das instituições confederais para a formação de um Estado federal, em uma recepção de regras do direito internacional convencional pelo direito interno de um Estado federal, podendo este, inclusive, utilizar-se do direito internacional costumeiro para regulamentar as relações recíprocas de seus Estados-membros (Les rapports, p.98); bem como uma aplicação do direito interno na esfera internacional nos casos somente em que os Estados indicam aquele direito por um "acordo especial", ocorrendo uma "recepção" do direito privado, de maneira "especial e limitada”, a um "caso particular” (Les rapports, p.102-103). Mas, apesar dessa mitigação, conclui Triepel que "não se pode admitir uma recepção de tal sorte operada de uma maneira generalizada. Para preencher as lacunas do direito internacional público, ele deve se socorrer de analogias baseadas nos principais princípios de seu próprio direito" (Les rapports, p.103).

${ }^{28}$ Les rapports, p.106 e seguintes.

${ }^{29}$ Corso, p.33-34.
} 
Direito interno internacionalmente relevante diz respeito aos atos normativos do direito interno cujo conteúdo reporta-se ao direito internacional assumido pelo Estado. Se o direito interno internacionalmente relevante reproduz o conteúdo do direito internacional assumido pelo Estado, este cumpre as suas obrigações junto ao direito internacional. Se, de maneira contrária, o direito interno internacionalmente relevante tem conteúdo contrário ao direito internacional assumido pelo Estado, comete este um ilícito internacional - ainda que o direito interno, para os dualistas, seja plenamente lícito, considerado em si mesmo, pois direito interno e direito internacional são, como visto, ordens jurídicas distintas e independentes ${ }^{30}$.

Direito interno internacionalmente irrelevante, ao contrário, diz respeito aos atos normativos do direito interno que não se reportam ao direito internacional assumido pelo Estado a que se refere. Seu conteúdo é, assim, indiferente para o direito internacional, não havendo possibilidade de o Estado cometer um ilícito internacional em razão desse direito interno.

Em síntese, não há, para os dualistas, direito internacional aplicado diretamente pelos operadores do direito interno. Há, sim, direito interno que corresponde ou deveria corresponder, em razão de seu conteúdo, ao direito internacional assumido pelo Estado, motivo pelo qual é denominado “internacionalmente relevante”.

Vale mencionar, para introduzir os derradeiros comentários sobre esse primeiro desdobramento da adoção do modelo dualista, um trecho do texto de Triepel em que o autor utiliza-se de um conhecido provérbio inglês: “O Parlamento é todo-poderoso; mas ele não pode transformar um homem em mulher. Poder-se-ia modificá-lo da seguinte maneira: A lei estatal é toda-poderosa. Mas como o direito internacional rege as relações entre Estados e o direito interno rege outras relações, a lei estatal não pode, sem transformação, mudar o direito internacional em direito interno”31.

Para o modelo dualista concebido inicialmente, há, pois, a necessidade de o direito interno reproduzir o conteúdo do direito internacional para que este tenha validade naquela ordem jurídica; é o que se denomina transformação, que se contrapõe à recepção ou incorporação, pela qual o próprio direito internacional é aplicado no

\footnotetext{
${ }^{30}$ Cf. Dionisio Anzilotti, Corso, p.34. Este assunto será retomado adiante, quando será objeto de algumas observações a responsabilidade internacional do Estado.

${ }^{31}$ Les rapports, p.91. Ambas as afirmações são, contudo, questionáveis hodiernamente; com relação à transformação do direito internacional em direito interno, tratar-se-á adiante.
} 
âmbito interno. Para tanto, o ato normativo utilizado deveria ser a lei, denominada por Triepel como uma "lei de execução",32.

Essa é a concepção dualista denominada pela doutrina, em momento posterior, de “dualismo radical”. Dualismo moderado seria, em sentido diverso, a concepção dualista que afirma a necessidade, sim, de um "ato de execução", fundado no direito interno, mas que não precisa necessariamente ser uma lei em sentido estrito, podendo ser, por exemplo, um simples decreto de execução.

A terceira conseqüência - impossibilidade de conflito entre o direito interno e o direito internacional - deriva logicamente da segunda.

Se o direito internacional e o direito interno regem relações sociais distintas, decorrem de fontes jurídicas igualmente díspares e não podem ser aplicados conjuntamente, vez que o direito internacional e o direito interno são esferas distintas que, tão somente, tangenciam-se, não existindo hipótese em que se possa vislumbrar conflito entre ambos.

Sobre esse aspecto, manifesta-se Triepel no sentido de que "o direito internacional público e o direito interno não são somente partes, ramos do direito distintos, mas também sistemas jurídicos distintos. São dois círculos que estão em contato íntimo, mas que nunca se sobrepõem. Visto que o direito interno e o direito internacional não regem as mesmas relações, é impossível que exista algum dia uma ‘concorrência’ entre as fontes de dois sistemas jurídicos”33.

Anzilotti, no mesmo sentido, arremata afirmando que "falar de conflitos entre direito internacional e direito interno é tão insensato quanto falar de conflitos entre as leis dos vários Estados”34.

Por fim, com relação à derradeira conseqüência da adoção do modelo dualista, deve-se observar que, caso o Estado edite direito interno internacionalmente relevante contrário ao direito internacional, a única decorrência desse ato estatal é a sua responsabilização no âmbito deste direito.

Não obstante a caracterização desse ilícito internacional e a conseqüente responsabilização do Estado, o direito interno contrário ao direito internacional vincula os indivíduos da mesma maneira que o direito interno a este conforme: o juiz, ao exercer a jurisdição, deve presumir que o direito interno obedece ao direito

\footnotetext{
${ }^{32}$ Les rapports, p.83, 89, 114, por exemplo.

${ }^{33}$ Les rapports, p.83.

${ }^{34}$ Corso, p.33.
} 
internacional, mas, ainda que assim não seja, a ele não é permitido colocar o direito internacional em posição de superioridade ao direito do seu próprio país ${ }^{35}$.

Ainda com relação à responsabilidade estatal, observa Triepel que o Estado também responde no âmbito do direito internacional pelos atos dos sujeitos a ele subordinados, sejam indivíduos ou seus próprios órgãos, em razão de sua soberania. Isso se aplica, dessa forma, aos Estados federais, respondendo estes pelos atos dos seus Estados-membros considerados ilícitos pelo direito internacional ${ }^{36}$.

Em síntese, pelo modelo dualista, direito interno e direito internacional são ordens jurídicas díspares e independentes, pois têm fontes jurídicas distintas. Por serem sistemas jurídicos que tratam de objetos distintos e que não se confundem, suas normas têm conteúdo igualmente distinto, o direito internacional não pode ser aplicado diretamente no âmbito interno, o direito interno não pode ser aplicado diretamente no âmbito internacional e, em razão disso, não há possibilidade de conflito entre ambos. No caso de o direito interno contrariar o direito internacional, aquele, no âmbito interno, é considerado lícito e deve ser aplicado pelo juiz, respondendo o Estado, por descumprimento de um compromisso, tão somente no âmbito internacional.

\subsubsection{O modelo monista.}

1.1.2.1. Fundamento teórico do modelo monista.

O modelo monista, por sua vez, concebido inicialmente por Hans Kelsen, tem na existência de uma única fonte jurídica internacional, decorrente da incompatibilidade de diversas fontes soberanas estatais concomitantes, seu fundamento teórico.

Para Kelsen, o Estado não é algo distinto do Direito; na verdade, o Estado é um ordenamento normativo, escalonado e hierarquizado ${ }^{37}$. Nesse sentido, os elementos que caracterizam o Estado, conforme a doutrina tradicional, nada mais são do que os aspectos territorial e pessoal de validade dessas normas jurídicas (território e povo), somados à força coercitiva, capaz de tornar essas normas eficazes - a própria validade

\footnotetext{
${ }^{35}$ Cf. Heinrich Triepel, Les rapports, p.104, Dionisio Anzilotti, Corso, p.34.

${ }^{36}$ Cf. Heinrich Triepel, Les rapports, p.116-118.

${ }^{37}$ Teoria pura, 246-308.
} 
dessa ordem jurídica (soberania) $)^{38}$. “O Estado não é senão a personificação do ordenamento jurídico"39.

Discutir a soberania estatal, para Kelsen, é “argumentar sobre uma hipótese de ciência jurídica” ${ }^{40}$. O problema não é de observação, mas de interpretação de certos fatos: pode-se partir tanto da hipótese do Estado como uma ordem suprema, soberana, como se pode partir da existência de uma ordem superior ao Estado, o direito internacional $^{41}$.

Assim, admitindo-se a primeira hipótese, um ordenamento jurídico ${ }^{42}$, simbolizado por uma pirâmide normativa, teria, em seu cume, uma norma mais alta e esta seria o fundamento de validade de todas as demais normas desse ordenamento. Essa norma superior a todas as outras é posta pelo primeiro legislador constituinte e esse ato, por ser instrumento de exercício da soberania estatal, faz com que se chegue, por fim, à norma que dá o fundamento último desse sistema normativo: a norma fundamental, que não é posta por ato nenhum, mas, sim, pressuposta, hipotética ${ }^{43}$.

Dessa forma, admitir a soberania estatal implica necessariamente em refutar a busca do princípio de validade desse ordenamento jurídico fora dele mesmo ${ }^{44}$. A norma fundamental pressuposta de um ordenamento estatal, por mais que não integre a sua pirâmide normativa, diz respeito unicamente a ele; cada ordenamento estatal teria a sua norma fundamental hipotética, fundamento último de validade de todas as demais normas jurídicas.

Trata-se aqui do raciocínio adotado pela teoria dualista: um Estado é soberano porque encontra o seu fundamento de validade nele próprio e em nenhuma outra fonte jurídica, seja ela de outro Estado, seja ela do direito internacional.

Assim, para que uma norma emanada de outro Estado ou do direito internacional tenha validade em um ordenamento jurídico, é preciso que este a reconheça, expressa ou tacitamente $^{45}$, transformando-a em direito estatal; somente a partir de então, poderá essa

\footnotetext{
${ }^{38}$ Les rapports, p.233-248.

${ }^{39}$ Cf. Hans Kelsen, Les rapports, p.242-243.

${ }^{40}$ Les rapports, p. 255.

${ }^{41}$ Les rapports, p. 255.

${ }^{42}$ Lembre-se que, para Kelsen, ordenamento jurídico e Estado não se distinguem.

${ }^{43}$ Cf. Hans Kelsen, Les rapports, p.259. Nos moldes da teoria constitucionalista, seria a positivação de uma Constituição no exercício do Poder Constituinte originário.

${ }^{44}$ Cf. Hans Kelsen, Les rapports, p.256.

${ }^{45}$ Kelsen aponta o reconhecimento tácito como uma ficção utilizada pelos partidários do dualismo para explicar a aplicação de determinadas normas internacionais em uma ordem estatal sem o seu expresso reconhecimento (reconhecimento expresso e reconhecimento tácito). Para Kelsen, esta ficção foi uma maneira encontrada pelos dualistas para explicar o que os monistas entendem por "validade objetiva” do
} 
norma “alienígena” ser aplicada pelos órgãos estatais. Kelsen afirma que o dualismo é, no fundo, um corolário do dogma da soberania; sob a aparência de uma teoria do direito internacional, ele é, na verdade, a sua negação ${ }^{46}$. Esse entendimento, segundo o autor, acarreta a negação da natureza jurídica tanto do direito internacional quanto do direito de outros Estados ${ }^{47}$; a essa negação que Kelsen denominou “egoísmo estatal”48.

Admitindo-se a segunda hipótese, qual seja a inexistência da soberania estatal, chega-se à existência de tão-somente uma ordem jurídica, superior ao Estado - o direito internacional. Este direito internacional nada mais é do que um ordenamento jurídico global, composto por suas normas próprias, escritas ou costumeiras ${ }^{49}$, e pelos diversos ordenamentos estatais. Os ordenamentos estatais são, nessa lógica, ordenamentos parciais $^{50}$.

A doutrina tradicional trata a soberania como absoluta, superlativa, mas, na verdade, ela é relativa. Como poderia um Estado soberano, superlativo, conviver com outro Estado também soberano? Em outras palavras, como poderia uma ordem jurídica ser a mais alta ao lado de outras que assim também pretendem ser?

Essa é a razão pela qual a doutrina se viu obrigada a distinguir duas soberanias, a soberania interior e a soberania exterior. Aquela, sim, é a expressão de relações de subordinação no âmbito do direito interno, mas esta é a expressão de relações de coordenação no âmbito do direito internacional, caracterizada pela igualdade jurídica entre os Estados. Trata-se, no entendimento de Kelsen, de uma contradição ${ }^{51}$.

Os Estados, segundo a doutrina tradicional, são juridicamente iguais; regem-se, pois, por relações de coordenação entre si, não por relações de subordinação. Ora, “toda coordenação supõe um elemento comum ao qual se reportam os elementos a coordenar" ${ }^{25}$. Decorre do exposto que a norma fundamental das diferentes ordens estatais é uma norma do direito internacional positivo, de conteúdo abstrato, que vale para todos os Estados, delimitando seu campo de atuação ${ }^{53}$.

direito internacional, pois este vincularia os sujeitos estatais independentemente de sua vontade (teoria objetiva e teoria subjetiva). Cf. Hans Kelsen, Les rapports, p.303

${ }^{46}$ Les rapports, p.288.

${ }^{47}$ Cf. Hans Kelsen, Les rapports, p.276-277.

${ }^{48}$ Les rapports, p.278.

${ }^{49}$ Kelsen, citando Grotius, distingue o direito internacional em “voluntário” ou "imutável e natural”, exemplificando este com o princípio do pacta sunt servanda.

${ }^{50}$ Cf. Hans Kelsen, Les rapports, p.299.

51 Les rapports, p.260. Kelsen também critica o conceito de soberania, afirmando que ele seria tautológico: um Estado é superior àquilo que lhe é subordinado.

${ }^{52}$ Cf. Hans Kelsen, Les rapports, p.260.

${ }^{53}$ Cf. Hans Kelsen, Les rapports, p.309. 
Os ordenamentos estatais não seriam, pois, soberanos, mas subordinados ao direito internacional. Alfred Verdross afirma que “o direito estatal somente pode moverse ‘com inteira liberdade’ dentro dos limites fixados pelo direito internacional”54. Agir com “inteira liberdade” dentro de determinados limites não é exercício de soberania.

Desconsiderando-se, dessa forma, a hipótese de haver uma norma fundamental estatal, descarta-se a noção de soberania e busca-se o fundamento de validade da ordem jurídica estatal, do próprio Estado, no direito internacional, em uma "norma fundamental de direito internacional”55.

Os direitos estatais são, enfim, ordens parciais, delegadas, que se reportam ao direito internacional, ordem jurídica global, fonte única de todas aquelas ordens jurídicas parciais. É o que Kelsen denomina de ordem universal ou civitas maxima ${ }^{56}$, cujas normas valem para todos os Estados ou seus órgãos, sem distinção ${ }^{57}$.

Entre os brasileiros, aderiram a esse modelo, por exemplo, Oscar Tenório ${ }^{58}$ e Haroldo Valladão ${ }^{59}$.

Posiciona-se Haroldo Valladão ao afirmar que “ a doutrina monista do primado do direito internacional, sem o panteísmo jurídico kelseniano da identificação do direito com o Estado e sem o seu metajuridicismo da norma básica, corresponde, a nosso ver, à realidade da organização jurídica da humanidade, com fonte original, objetiva e única, decorrendo ou do renascido direito natural ou da imperiosidade da vida social, e se desenvolvendo de um direito internacional superior aos vários direitos subordinados, direitos internos, e nestes, da norma constitucional à legal e à regulamentar, e, em todas, às normas emanadas da autorizada autonomia da vontade” ${ }^{\text {. }}$.

1.1.2.2. Conseqüências da adoção do modelo monista.

De todo o exposto, podem ser extraídas três conseqüências decorrentes da adoção do modelo monista: (1) é perfeitamente possível um ato normativo do direito

\footnotetext{
${ }^{54}$ Derecho internacional, p.65. Kelsen, em sua Teoria pura, p.376, afirma que os Estados já não têm uma competência soberana, mas têm, no entanto, uma "pretensão à totalidade", somente limitada pelo direito internacional, uma vez que podem as ordens estatais editar normas, em princípio, sobre todas as matérias, até que o direito internacional se aposse de alguma delas.

${ }^{55}$ Cf. Hans Kelsen, Les rapports, p.310, e, do mesmo autor, Teoria pura, p.240.

${ }^{56}$ Les rapports, p.317. Kelsen fala ainda em um Estado mundial em sua Teoria pura, p.364, apesar de admitir que, presentemente, não se pode falar de uma tal comunidade.

${ }^{57}$ Les rapports, p.299.

${ }^{58}$ Direito internacional privado, p.26-33.

${ }^{59}$ Direito internacional privado, p.53.

${ }^{60}$ Direito internacional privado, p.53.
} 
internacional ser aplicado no âmbito interno estatal, ademais, o direito internacional, em regra, deve ser aplicado obrigatoriamente pelos Estados; (2) como os âmbitos de validade das normas estatais e internacionais podem coincidir, pode haver conflito entre uma norma de direito interno e outra de direito internacional; (3) em caso de um Estado, por meio de seu ordenamento interno, violar o direito internacional, cabe a este, por seus órgãos, sancionar o Estado infrator.

Pela primeira delas, não existe um princípio da impenetrabilidade do Estado, segundo o qual nenhum ato jurídico proveniente de outro Estado ou do próprio direito internacional pode ser aplicado em seu território ${ }^{61}$. É possível a aplicação imediata do direito internacional pelos tribunais estatais ${ }^{62}$.

Não há dúvidas também que um mesmo indivíduo, nacional de determinado Estado, possa ser objeto de normas jurídicas provenientes tanto de seu próprio Estado, quanto de outros Estados, ou até mesmo diretamente do direito internacional ${ }^{63}$. Ambos os âmbitos de validade são limitados e determinados pelo direito internacional.

Nesse mesmo sentido, afirma Alfred Verdross que não cabe pôr em dúvida que um tratado internacional ou mesmo determinadas normas do direito internacional consuetudinário, longe de serem exclusivamente fontes de direito internacional, podem obrigar também no âmbito interno de um Estado, sendo, inclusive, diretamente obrigatória dos indivíduos. Os indivíduos podem estar “diretamente conectados” com o direito internacional ${ }^{64}$.

Uma segunda conseqüência, decorrente da primeira, é que, considerado existir um único sistema normativo global, pode haver conflito entre as suas normas ${ }^{65}$. Esses conflitos, todavia, não são reais: o próprio sistema traz os métodos necessários para resolvê-los, revelando-os como conflitos aparentes, preservando-se, assim, a sua coerência interna ${ }^{66}$.

${ }^{61}$ Cf. Hans Kelsen, Les rapports, p.250-251.

${ }^{62}$ Cf. Alfred Verdross, Derecho internacional, p.69-70. No entanto, entendendo-se que existe uma validade interna do direito internacional distinta de sua validade internacional, poderia um tribunal estatal aplicar uma norma interna contrária ao direito internacional, o que acarretaria a necessidade de aplicação de uma sanção pelos tribunais internacionais, como se verá adiante, sanção essa que reafirma a essência monista.

${ }^{63}$ Cf. Hans Kelsen, Les rapports, p.266.

${ }^{64}$ Derecho internacional, p.64.

${ }^{65}$ Kelsen, em sua Teoria pura, p.366, afirma que não há conflitos entre direito internacional e direito estatal, mas essa afirmação é feita no sentido de que não há conflitos reais entre essas normas, sem possíveis soluções. Uma norma estatal "contrária” ao direito internacional é anulável, mantendo a sua validade enquanto não for anulada por decisão de um órgão competente; dessa forma manter-se-ia uma "coerência" da ordem jurídica mundial.

${ }^{66}$ Cf. Hans Kelsen, Les rapports, p.267-274. 
Assim também expôs Verdross no sentido de que se deve reconhecer a possibilidade de conflitos entre direito internacional e direito interno, mas tais conflitos “não têm caráter definitivo e encontram sua solução na unidade do sistema jurídico”,67.

O principal dos critérios analisados é o da hierarquia, segundo o qual norma hierarquicamente superior prevalece sobre norma hierarquicamente inferior. E esse critério é de fato importante quando se toma por fundamento que as ordens estatais são parciais e se subordinam à ordem internacional $^{68}$.

Assim, os atos normativos estatais contrários ao direito internacional são anuláveis, desde que esteja previsto um processo por meio do qual a norma estatal contrária ao direito internacional possa ser anulada ${ }^{69}$; trata-se do monismo "radical” ou monismo com primazia do direito internacional, conforme denominação da doutrina ${ }^{70}$. Ser um ato anulável significa que a ordem inferior delegada é autorizada a revogar, ainda que provisoriamente e por tempo limitado, a ordem superior, vez que, até que se efetive a sua anulação, esses atos são válidos ${ }^{71}$.

Pode acontecer também que a ordem superior autorize expressamente a ordem parcial a editar, em caso de necessidade, atos normativos contrários a ela, revogando suas normas definitivamente ${ }^{72}$. Essa autorização permite claramente que, em caso de conflito entre norma estatal e norma internacional, aquela prevaleça, abrindo-se a oportunidade do que veio a ser denominado monismo "moderado" ou monismo com primazia do direito interno ${ }^{73}$.

${ }^{67}$ Derecho internacional, p.65.

${ }^{68} \mathrm{O}$ direito internacional teria igualmente, segundo Hans Kelsen, Teoria pura, p.359-360, uma estrutura escalonada e hierarquizada: o direito internacional geral (composto, por exemplo, pela fórmula pacta sunt servanda) subordina o direito internacional convencional (tratados e convenções, entre outros), que, por sua vez, é superior às normas criadas por tribunais internacionais e por outros órgãos internacionais pactualmente constituídos.

${ }^{69}$ Cf. Hans Kelsen, Teoria pura, p.366-368.

${ }^{70}$ Monismo "radical" ou monismo com primazia do direito internacional seria a concepção segundo a qual os direitos estatais, por serem parciais, estariam subordinados ao direito internacional, ordem jurídica universal, prevalecendo sempre as normas deste em caso de conflito, por serem hierarquicamente superiores; diferentemente do monismo "moderado" ou monismo com primazia do direito interno, pelo qual, em caso de conflito entre norma dos direitos internos e norma do direito internacional, prevalece aquela, mas por expressa autorização desta ordem universal. Cf. Alfred Verdross, Derecho internacional, p.63. Esta dicotomia não será analisada mais atentamente, vez que não descaracteriza o modelo monista em sua essência.

${ }^{71}$ Cf. Hans Kelsen, Les rapports, p.273. Kelsen afirma ser mais comum a sanção de anulabilidade, o que pode decorrer de convicções próprias, bem expostas em sua Teoria pura, 306-308. Alfred Verdross, por sua vez, entende ser a norma nula, ainda que com certa vacilação, vez que os Estados aplicam atos contrários ao direito internacional com efeitos “internos e provisórios”, Derecho internacional, p.64-65.

${ }^{72}$ Cf. Hans Kelsen, Les rapports, p.273-274.

${ }^{73}$ Algumas Constituições, como a de Weimar de 1919 e a da Irlanda de 1937, trazem normas que dispõe, de maneira geral, que o direito internacional é obrigatório e parte integrante do direito interno, dando a infeliz sensação, nos dizeres de Verdross, de que a validade internacional do direito internacional com 
Deve-se observar, contudo, que esta distinção em nada descaracteriza a essência do modelo monista, qual seja a inexistência de ordens estatais soberanas. Afinal, estas ordens estatais não contrariam o direito internacional no exercício de sua soberania, por força própria, mas tão-somente no exercício de uma autorização expressa deste direito internacional, por força deste direito, que lhe é superior.

Por fim, pode o Estado determinar a maneira pela qual cumprirá suas obrigações decorrentes do direito internacional. Segundo Verdross, o direito internacional tem a sua validade internacional independentemente do reconhecimento dos Estados, obrigandoos, em regra, com seus dispositivos, mas a maneira pela qual o Estado cumpre internamente as suas obrigações internacionais cabe a ele determinar, exercendo, assim, a ordem parcial parcela de liberdade delegada pela ordem universal ${ }^{74}$.

Por fim, uma terceira conseqüência diz respeito ao descumprimento do direito internacional por parte dos Estados. Kelsen afirma que a guerra é uma sanção do direito internacional, ou seja, é um ato jurídico, e não extrajurídico, ainda que típico de um “direito primitivo"75.

Verdross, por sua vez, em razão do momento histórico posterior ao de Kelsen em que analisa a questão, considera a possibilidade de tribunais internacionais, após

relação aos Estados depende das Constituições estatais, vez que o direito internacional somente vincularia aqueles Estados que tenham reconhecido as suas normas; na verdade, para o autor, o que ocorre é que o direito interno, ao invocar o direito internacional, reconhece a sua autoridade e submete-se a ele. Esta referência, conclui, é supérflua, pois a validade internacional do direito internacional depende unicamente da constituição desta comunidade internacional, e não da constituição deste ou daquele Estado. Derecho internacional, p.67-68.

Kelsen, em sua Teoria pura, 374-377, retoma o tema, afirmando que o primado do direito internacional é compatível com o fato de a Constituição de um Estado conter preceitos que exigem a "transformação" do direito internacional em direito interno para que aquele possa ser aplicado pelos órgãos estatais; isso se torna necessário quando esses órgãos estatais somente estão autorizados pela Constituição a aplicar o direito internacional quando o seu conteúdo tenha revestido a forma de direito estatal. Essas observações do autor dariam a impressão que teria passado a adotar o modelo monista "moderado" ou com primazia do direito interno, mas não é isso que se extrai de uma leitura mais atenta, pois, logo na p.375, Kelsen sustenta que "se, na falta de uma norma de transformação, não pode ser aplicada, num caso concreto, uma norma de Direito internacional que a esse caso se refira, isso significa, quando se parta da validade do Direito internacional, não que esta norma de Direito internacional não tenha qualquer validade em relação ao Estado, mas apenas que, quando ela não é aplicada e, conseqüentemente, o Direito internacional é violado pela conduta do Estado, este se expõe à sanção que o Direito internacional estatui como conseqüência de tal conduta”.

A discussão continua nas páginas seguintes, p.377-381, nas quais Kelsen afirma haver uma diferença no fundamento de validade das normas internacionais aplicadas pelo ordenamento interno, para, por fim, chegar às mesmas conclusões para ambos os modelos, excluindo a possibilidade de a ordem estatal ser soberana - soberana é a ordem internacional, reconhecida pela ordem jurídica estadual em sentido amplo. A questão parece ter sido posta por Hans Kelsen motivada por uma necessidade de adequação de sua teoria aos fatos observados nos Estados

${ }^{74}$ Derecho internacional, p.68.

${ }^{75}$ Les rapports, p.317-318. Em sua Teoria pura, p.355-359, Kelsen igualmente analisa a guerra e a represália como sanções do direito internacional, entendida como de uma “ordem jurídica primitiva”. 
identificarem uma contradição entre norma estatal, inclusive constitucional, e norma internacional, imporem ao Estado a revogação dessa norma ou, pelo menos, a sua não aplicação. "Nenhum Estado pode subtrair-se a uma obrigação jurídico-internacional invocando seu direito interno" ${ }^{, 76}$.

1.2. Os fundamentos teóricos dos modelos e suas conseqüências na atualidade.

Feita a descrição dos modelos dualista e monista, deve-se passar à análise crítica da persistência ou da superação de seus fundamentos e, por decorrência, de suas conseqüências na atualidade. A viabilidade dos fundamentos de um modelo faz com que a sua vigência atual nas relações entre direito internacional e direito interno seja igualmente viável; a sua insustentabilidade, por via inversa, acarreta a superação do próprio modelo.

Serão analisados, assim, os fundamentos teóricos tanto do monismo quanto do dualismo, para que se vislumbre a vigência atual de um deles. Identificado o modelo vigente, deve-se passar, necessariamente, a uma discussão sobre as conseqüências de sua adoção. Sim, porque, ainda que persistam os fundamentos de determinado modelo, as suas conseqüências podem ser outras, dada a visível alteração do cenário global desde que ambos os modelos foram concebidos.

1.2.1. Soberania estatal: incompatibilidade com o modelo monista.

Inicia-se o plano deste ponto com o confronto entre soberania estatal e o modelo monista. Pelo exposto anteriormente, ficou claro que a adoção do modelo monista de ralação entre direito interno e direito internacional exclui necessariamente a soberania estatal; na verdade, exclui a própria existência de direitos internos soberanos. Soberana é somente a ordem internacional, sendo cada ordem nacional uma parcela delegada daquela e, pois, subordinada àquela; os Estados seriam, dessa forma, não soberanos, mas autônomos ${ }^{77}$.

Quanto à incompatibilidade entre soberania e monismo não restam dúvidas.

\footnotetext{
${ }^{76}$ Derecho internacional, p.65-66. Ainda que o mesmo autor admita em momento posterior (p.71-72) que o direito internacional não conhece uma jurisdição obrigatória, vez que o exercício desta depende do expresso reconhecimento de sua competência pelas partes em litígio.

${ }^{77}$ Tanto no monismo "radical" quanto no "moderado", como visto anteriormente.
} 
Deve-se, assim, apontar que a inexistência da soberania estatal é fundamento da vigência do modelo monista, e não o inverso: não é uma simples opção aleatória entre o modelo dualista ou o monista que confirmará a existência da soberania estatal ou a sepultará.

Tomando-se por premissa a inexistência da soberania estatal, pode-se afirmar a viabilidade do modelo monista; tomando-se, de modo inverso, a existência da soberania estatal, torna-se insustentável esse modelo. Há, assim, uma clara relação de prejudicialidade entre a existência ou não da soberania estatal e a vigência do modelo monista.

No que concerne ao conceito de soberania, Dalmo de Abreu Dallari apresenta três concepções distintas. Para a primeira delas, de fundamento político, “a soberania expressava a plena eficácia do poder, sendo conceituada como o poder incontrastável de querer coercitivamente e de fixar as competências”, tendo sido estimulado, em razão dessa concepção, "um verdadeiro egoísmo entre grandes Estados, pois todos se afirmavam soberanos e só agiam como tais aqueles que tivessem força para tanto”78.

Para uma segunda concepção, puramente jurídica, a soberania é “o poder de decidir em última instância sobre a atributividade das normas, vale dizer, sobre a eficácia do direito". Segue Dallari, afirmando que "fica evidente, embora continuando a ser uma expressão de poder, a soberania é poder jurídico utilizado para fins jurídicos. Partindo do pressuposto de que todos os atos dos Estados são passíveis de enquadramento jurídico, tem-se como soberano o poder que decide qual a regra jurídica aplicável em cada caso, podendo, inclusive, negar a juridicidade da norma. Segundo essa concepção não há Estados mais fortes ou mais fracos, uma vez que para todos a noção de direito é a mesma. A grande vantagem dessa conceituação jurídica é que mesmo os atos praticados pelos Estados mais fortes podem ser qualificados como antijurídicos, permitindo e favorecendo a reação de todos os demais Estados”79.

Por fim, para uma terceira concepção, denominada culturalista, pela qual não se admite nem a noção exclusivamente política, nem a meramente jurídica, a soberania não é simplesmente o uso da força, mas também não está submetida totalmente ao direito. Assim, a soberania, ainda nas palavras de Dalmo Dallari, “jamais é a simples expressão de um poder de fato, embora não seja integralmente submetida ao direito, encontrando seus limites na exigência de jamais contrariar os fins éticos de convivência,

\footnotetext{
${ }^{78}$ Elementos, p.79-80.

${ }^{79}$ Elementos, p.80.
} 
compreendidos dentro da noção de bem comum. Dentro desses limites o poder soberano tem a faculdade de utilizar a coação para impor suas decisões” ${ }^{\text {" }}$.

Independentemente do conteúdo que se atribua à soberania - e, nesse passo, a concepção culturalista, por combinar aspectos políticos e jurídicos do fenômeno, parece ser a que melhor explica a realidade -, ela persiste no cenário internacional atual, apesar das tentativas de enfraquecê-la ou até mesmo sepultá-la. Para Fernanda Dias Menezes de Almeida, “a soberania tem ainda peso importante na incorporação dos tratados, com sua conseqüente aplicação e execução no plano interno do Estado que o celebra”81.

Manoel Gonçalves Ferreira Filho afirma ser “incontestável que hoje quando se fala em Estado vem à mente a idéia de uma ordem estatal não submetida a outra ordem da mesma espécie. E essa ausência de subordinação é em última análise a soberania. Traço hoje reputado imprescindível ao Estado",82. Ao tratar sobre a tendência a sujeitar os Estados a uma ordem internacional, sustenta Ferreira Filho que "essa tendência integradora tem hoje uma força e uma amplitude que nunca se manifestou antes na História. Sem dúvida, o primeiro impulso que nela se faz presente é a velha necessidade de segurança que sempre através dos tempos levou os Estados a aliarem-se uns aos outros. A unificação do globo produzida pelo progresso dos meios de comunicação, o sentimento de independência resultante do intercâmbio econômico, a aproximação das culturas, o reconhecimento da igualdade da natureza humana, etc., tudo isso contribuiu para a integração internacional. Não chegou esta, porém, a firmar o princípio da supremacia da ordem internacional em outra base que não a da voluntária submissão dos Estados”83.

Paulo Bonavides observa que, “ao termo da Idade Média e começo da primeira revolução iluminista que foi a Renascença, brilhante precursora da segunda revolução, a revolução da razão, ocorrida no século XVIII, o Estado Moderno já manifestava traços inconfundíveis de sua aplicação cristalizada naquele conceito sumo e unificador - o de soberania, que ainda hoje é seu traço mais característico, sem embargos das relutâncias globalizadoras e neoliberais convergentes no sentido de expurgá-lo das teorias contemporâneas de poder”, ${ }^{\text {. }}$.

\footnotetext{
${ }^{80}$ Elementos, p.80-81.

${ }^{81}$ A incorporação dos tratados, p.50-51.

${ }^{82}$ Curso, p.48.

${ }^{83}$ Curso, p.49-50.

${ }^{84}$ Teoria do Estado, p.29.
} 
Bonavides destaca, contudo, a necessidade de se criar uma ordem internacional com primazia sobre a ordem nacional como um motivo "que concorre fortemente para abater o princípio da soberania”, afirmando que "os internacionalistas são homens que vêem sempre com suspeição o princípio da soberania. Não apenas com suspeição, senão como se fora ele obstáculo à realização da comunidade internacional, à positivação do direito internacional, à passagem do direito internacional, de um direito de bases meramente contratuais, apoiado em princípios de direito natural, de fundamentos tãosomente éticos ou racionais, a um direito que coercitivamente se pudesse impor a todos os Estados ${ }^{\prime 85}$.

Não negando os problemas teóricos relativos à soberania, Jorge Miranda, por sua vez, sustenta que, “embora o conceito correspondente não possua hoje compreensão idêntica à que tinha há 400 ou há 100 anos, tem sobrevivido, suscetível de adaptações e de reconvenções. Não por acaso quer a generalidade das Constituições, quer a própria Carta das Nações Unidas (art.2 ${ }^{\circ}, \mathrm{n}^{\circ} 1$ ) continuam a fazer-lhe apelo”86.

Por fim, a soberania estatal, mais uma vez segundo Dalmo de Abreu Dallari, não obstante a imprecisão e as controvérsias com relação ao seu conceito, “é uma das bases da idéia de Estado Moderno, tendo sido de excepcional importância para que este se definisse, exercendo grande influência prática nos últimos séculos, sendo ainda uma característica fundamental do Estado ${ }^{\text {87 }}$.

Do exposto, afirma-se ser imprescindível considerar-se a soberania estatal nas relações entre o direito internacional e o direito interno, apesar das profundas alterações pelas quais tem passado a ordem global, sobretudo no último século. Ao considerar cada Estado como soberano, deve-se afastar, por conseqüência, a vigência do modelo monista nas relações entre direito internacional e direito interno.

1.2.2. A existência de fontes jurídicas diversas como decorrência da soberania estatal.

Excluída a possibilidade de vigência do modelo monista na atualidade, em razão de sua incompatibilidade com a soberania estatal, deve-se passar à discussão sobre a viabilidade da vigência do modelo dualista.

\footnotetext{
${ }^{85}$ Ciência política, p.132-133.

${ }^{86}$ Teoria do Estado, p.219.

${ }^{87}$ Elementos, p.74-75.
} 
Assenta-se o modelo dualista, como visto anteriormente, na idéia de que ordenamentos internos e ordenamento internacional fundamentam-se em fontes jurídicas distintas.

A adoção da soberania estatal como pressuposto da análise das relações entre o direito interno e o direito internacional faz com que se conceba, primeiro, a existência não de um único ordenamento jurídico global, mas a existência de uma pluralidade de ordenamentos estatais, distintos do ordenamento internacional e, segundo, que esses ordenamentos são fundamentados em fontes jurídicas distintas: as ordens internas têm por fonte o poder soberano de seu próprio Estado e a ordem internacional tem por fonte o consenso dessas soberanias estatais, seja ele expresso ou tácito.

Com relação à existência de uma pluralidade de ordenamentos, Norberto Bobbio apresenta a questão afirmando que o ideal de um monismo jurídico, baseado na idéia universalista de que existe tão somente um ordenamento jurídico universal decaiu, principalmente, em razão de duas fases que se sucederam no tempo ${ }^{88}$.

A primeira delas, segundo Bobbio, denomina-se "historicismo jurídico”, que, “sobretudo através da escola histórica do Direito, afirma a nacionalidade dos direitos que emanam direta ou indiretamente da consciência popular", de caráter "estatalista”. “Essa fragmentação do Direito Universal em tantos Direitos particulares, interdependentes entre si, é confirmada e teorizada pela corrente jurídica que acabou por prevalecer na segunda metade do século passado”, referindo-se Bobbio ao positivismo jurídico, “corrente segundo a qual não existe outro Direito além do Direito positivo, e a característica do Direito positivo é ser criado por uma vontade soberana”89.

Segue Bobbio, afirmando que "a segunda fase do pluralismo jurídico é aquela que podemos chamar de institucional (para distingui-la da primeira, que podemos chamar de estatal ou nacional). Aqui 'pluralismo' tem um significado mais pleno (tanto que, se se fala em 'pluralismo' sem maiores especificações, nos referimos a esta corrente e não à precedente): significa não somente que há muitos ordenamentos jurídicos (mas todos do mesmo tipo), em contraposição ao Direito universal único, mas que há ordenamentos jurídicos de muitos e variados tipos. Chamamo-lo de ‘institucional' porque a sua tese principal é a de que existe um ordenamento jurídico onde existe uma instituição, ou seja, um grupo social organizado"90.

\footnotetext{
${ }^{88}$ Teoria do ordenamento, p.162.

${ }^{89}$ Teoria do ordenamento, p.162.

${ }^{90}$ Teoria do ordenamento, p.163.
} 
Não se pretende aqui discutir minuciosamente a abrangência e a extensão da adesão à teoria "estatal” ou à teoria "institucional” sobre o pluralismo jurídico, ainda que a doutrina internacionalista pareça tender à teoria institucional, já que, como se pode extrair do entendimento de eminentes internacionalistas, entes não-estatais, como a Santa Sé ou a Cruz Vermelha, figuram como fontes produtoras do direito internacional $^{91}$.

A teoria "institucional” soma-se à teoria "estatal”, acrescendo-lhe, como visto, a possibilidade de entes não-estatais figurarem como fontes produtoras do direito internacional, não excluindo, contudo, os fundamentos sob os quais se assenta o pluralismo jurídico: os ordenamentos jurídicos emanam do que Bobbio apontou como “consciência popular”, jurídicos fundamentam-se no exercício da soberania - poder político - pelo povo de um determinado território. Em última análise, trata-se da teoria do poder constituinte e de sua titularidade ${ }^{93}$.

Nesse sentido, Miguel Reale sustenta, antes de contrapor direito interno e direito internacional, que “pela palavra 'território’ não devemos entender apenas o assento geográfico, em que reside certa coletividade. Território é a expressão técnica que serve para delimitar a zona de interferência ou de incidência do poder político. Território é, portanto, o espaço social submetido à soberania jurídica e política de um determinado Estado",94.

Cabe observar, assim, ainda nas lições de Reale, que "a coexistência de ‘territórios’ distintos, cada qual sujeito a uma ordem jurídica soberana, já impõe uma distinção entre regras jurídicas de Direito Interno e regras jurídicas de Direito Externo. De maneira geral, podemos dizer que a validade das primeiras se reporta, direta ou indiretamente, ao Estado, que pode ser visto como o centro de polarização da positividade jurídica, ou, por outras palavras, como a ordenação de poder em virtude da qual as normas jurídicas obrigam, tornando-se objetivamente exigível o comportamento que elas prescrevem"

\footnotetext{
${ }^{91}$ Cf. José Francisco Rezek, Direito dos tratados, p.51-54, Guido Fernando Silva Soares, Curso, p.158162, Celso D. de Albuquerque Mello, Curso, p.531-570.

${ }^{92}$ Teoria do ordenamento, p.162.

${ }^{93}$ Sobre a teoria do poder constituinte, cf. Manoel Gonçalves Ferreira Filho, O poder constituinte, José Afonso da Silva, Poder constituinte.

${ }^{94}$ Lições preliminares, p.344.

${ }^{95}$ Lições preliminares, p.118.
} 
É, dessa forma, de uma fonte jurídica estatal que decorrem as normas de um determinado ordenamento interno e, por conseqüência, é tão-somente nessa fonte que todo esse ordenamento jurídico encontra seu fundamento, e não em qualquer outra fonte, seja ela de outro ordenamento estatal, seja ela do próprio direito internacional.

Na sociedade internacional, por outro lado, “o poder político, regulado juridicamente, não se encontra concentrado num órgão dotado de capacidade de subordinação dos demais ao império das leis. Pelo contrário, esse poder é atomizado de tal forma que os Estados e organizações legiferantes atuam no campo da coordenação. Essa característica vem acentuada em todos os autores nacionais e estrangeiros”96.

Do exposto, transparece a idéia de que as normas aplicadas em determinada ordem jurídica interna encontram fundamento em sua soberania estatal, advindo dessa fonte interna de maneira direta ou indireta, enquanto que as normas aplicadas na ordem jurídica internacional encontram fundamento, principalmente, no consenso interestatal, advindo dessa fonte internacional, também de maneira direta ou indireta.

Persiste, dessa forma, o modelo dualista, pois persiste o seu fundamento no atual concerto internacional.

1.2.3. A vigência do modelo dualista: análise crítica de suas conseqüências.

Excluída a possibilidade de vigência do modelo monista, dadas a sua incompatibilidade com a soberania estatal e a permanência desse atributo do poder político estatal hodiernamente, passou-se ao questionamento da viabilidade do modelo dualistas, por meio da discussão de seu fundamento.

Da contraposição entre o modelo monista e a soberania estatal, deve-se reafirmar que esta soberania persiste no cenário global atual, ainda que não nos mesmos termos de sua concepção, e é no exercício desse poder político pelo seu titular que se fundamenta a aplicação de todo o direito no âmbito territorial de um determinado Estado. Não se pode conceber, tomando-se por premissa a soberania estatal, a aplicação do direito internacional no âmbito territorial de um dado Estado sem o seu consentimento, como propõe o modelo monista.

É claro o entendimento de José Francisco Rezek no sentido de que, “no estágio presente das relações internacionais, é inconcebível que uma norma jurídica se imponha

\footnotetext{
${ }^{96}$ Cf. José Roberto Franco da Fonseca, Especificidades, p.208.
} 
ao Estado soberano à sua revelia. Para todo Estado, o direito das gentes é o acervo normativo que, no plano internacional, tenha feito objeto de seu consentimento, sob qualquer forma” ${ }^{97}$. Parte-se, pois, à análise dos fundamentos do modelo dualista tomando-se por premissa a soberania estatal.

Com relação ao dualismo, a persistência de seu fundamento, contudo, não exclui o questionamento da persistência de suas conseqüências. As relações internacionais alteram-se com o passar do tempo e as conseqüências apontadas pelos idealizadores do modelo vinculavam-se às circunstâncias de sua época. Deve-se passar, assim, à análise de suas conseqüências no estágio atual do concerto internacional.

Como visto anteriormente, conseqüências da adoção desse modelo, apontadas por Triepel ${ }^{98}$, são (1) o direito internacional e o direito interno têm normas com objetos distintos, pois regem relações sociais igualmente distintas, (2) a impossibilidade de um ato normativo de direito internacional ser aplicado no direito interno e de um ato normativo de direito interno ser aplicado no direito internacional, (3) a impossibilidade de haver conflito entre normas de direito internacional e normas de direito interno e (4) a responsabilidade internacional do Estado, no caso de o direito interno dispor de maneira contrária ao direito internacional assumido pelo Estado.

1.2.3.1. O conteúdo diverso das normas de direito interno e de direito internacional: superação de uma das conseqüências do modelo dualista.

Afirma-se que as normas de direito internacional têm por objeto a conduta dos sujeitos de direito internacional, principalmente os Estados, e que as normas de direito interno têm por objeto a conduta dos indivíduos sujeitos à sua soberania.

Contudo, uma análise mais detida dos tratados internacionais ratificados pelos Estados, sobretudo após a Segunda Guerra Mundial, leva à conclusão que esses atos normativos internacionais passaram a dispor sobre as relações interindividuais, de direito privado ou de direito público, e não mais somente tratam das relações entre os Estados, dispondo sobre temas relativos a territórios, relações consulares e diplomáticas, entre outros.

Esses tratados mais recentes versam, principalmente, sobre direitos humanos, em clara reação às atrocidades cometidas pelos regimes autoritários e totalitários durante a

\footnotetext{
${ }^{97}$ Direito internacional público, p.78.

${ }^{98}$ Les rapports, p.83-84.
} 
Segunda Guerra Mundial. Basta observar a obra de Vicente Marotta Rangel, Direito e relações internacionais ${ }^{99}$, para arrolar uma série de documentos que tratam diretamente de direitos e garantias fundamentais do ser humano, entre eles a Convenção Americana sobre Direitos Humanos. Com relação a esta, também conhecida como Pacto de São José da Costa Rica, todos os seus dispositivos de direito material, que prevêem direitos civis e políticos - direito ao reconhecimento da personalidade jurídica, direito à integridade pessoal, direito à liberdade pessoal, entre outros - direcionam-se de maneira direta aos indivíduos, e não ao Estado ${ }^{100}$.

Conforme José Roberto Franco da Fonseca, "hoje afirma-se cada vez mais a eminência do indivíduo, da pessoa como titular subjetivo de direito internacional público, pois a matéria de direitos fundamentais, dada a universalidade do valor da dignidade humana, transcende os limites fronteiriços dos ordenamentos internos, para ganhar destaque no ordenamento jurídico internacional”101.

Por sua vez, pondera Raul Machado Horta que se alcançou “a plenitude jurídica dos direitos individuais quando, rompendo-se as resistências da soberania estatal, formulou-se a Declaração Universal dos Direitos Humanos, em 10 de dezembro de 1948, incorporando ao Direito Internacional os direitos anteriormente reconhecidos na Constituição do Estado”, superando-se “a fase em que esses direitos eram considerados assuntos pertinentes ao domínio exclusivo dos Estados”102.

Ainda com relação ao tema, não se deve confundir a afirmação de o indivíduo ser objeto das normas de direito internacional com a de o indivíduo integrar as fontes do direito internacional.

Pela primeira afirmação, a norma de direito internacional pode ter por objeto, por conteúdo, a conduta do indivíduo, do ser humano, atribuindo-lhe direitos e deveres diretamente, e não somente a conduta estatal; pela segunda, o indivíduo, ao lado dos Estados, das Organizações Internacionais e de outros entes não-estatais, seria uma fonte produtora de direito internacional, sendo, portanto, capaz de elaborar atos normativos destinados a produzir efeitos jurídicos nessa ordem jurídica internacional, como celebrar tratados internacionais ou mesmo reconhecer Estados estrangeiros. Pela primeira, o

\footnotetext{
${ }^{99}$ São, nessa obra citada, nove documentos de grande importância, tanto do sistema mundial quanto do sistema regional de proteção dos direitos humanos, p.643-757.

${ }^{100} E$ praticamente todos esses dispositivos de direito material encontram-se previstos na Constituição da República Federativa do Brasil, cf. Marco Antonio Corrêa Monteiro, Ánálise comparativa, p.718-720.

${ }^{101}$ Especificidades, p.205.

${ }^{102}$ Direito constitucional, p.231-232.
} 
indivíduo assumiria uma posição passiva, objeto das normas internacionais; pela segunda, assumiria uma posição ativa, de produção dessas normas.

O que se sustenta aqui é a primeira afirmação, e não a segunda. O fato de o indivíduo passar a figurar como destinatário das normas internacionais, principalmente com relação a direitos humanos, ou as situações excepcionais em que esse indivíduo pode participar ativamente no âmbito internacional, por exemplo, apresentando à Comissão Interamericana de Direitos Humanos petições que contenham denúncias ou queixas de violação dos direitos previstos na Convenção Interamericana de Direitos Humanos (artigo 44 da Convenção), não fazem dele uma fonte produtora de direito internacional $^{103}$.

Em suma, conclui-se que não mais têm as normas de direito internacional e de direito interno conteúdos distintos. Evoluiu a ordem internacional e as relações entre os Estados, não mais se podendo sustentar a existência de tal distinção.

1.2.3.2. A possibilidade de um ato normativo de direito internacional ser aplicado no direito interno.

Deve-se afirmar, inicialmente, que não se sustenta mais a inaplicação do direito internacional no âmbito interno. Já Triepel, ao construir seu modelo dualista, deparou-se com o problema: teve o autor que equacionar sua teoria em face da afirmação da doutrina inglesa que afirmava que o direito internacional faz parte da common law e da Constituição norte-americana, em seu art. $6^{\circ}$, que dispunha que os tratados internacionais compõem o direito da terra - law of the land $^{104}$.

A Constituição da República Federativa do Brasil de 1988 seguiu no mesmo sentido. Em seu artigo 102, III, b, o texto constitucional atual, seguindo a tradição que vem desde a Constituição de $1891^{105}$, atribui ao Supremo Tribunal Federal a competência para declarar a inconstitucionalidade de tratados internacionais, o que pressupõe que estes integram o ordenamento jurídico brasileiro ${ }^{106}$. Igualmente o $\S 3^{\circ}$ do

\footnotetext{
${ }^{103}$ Cf. Guido Fernando Silva Soares, Curso, p.155-158. Sobre os sujeitos de direito internacional, cf. José Francisco Rezek, Direito dos tratados, p.25-70.

${ }^{104}$ Les rapports, p.89-91.

105 “Artigo 59. Ao Supremo Tribunal Federal compete: (...) §1 $1^{\circ}$ Das sentenças das justiças dos Estados em última instância haverá recurso para o Supremo Tribunal Federal: a) quando se questionar sobre a validade ou a aplicação de tratados e leis federais, e a decisão do tribunal do Estado for contra ela”.

106 "Artigo 102. Compete ao Supremo Tribunal Federal, precipuamente, a guarda da Constituição, cabendo-lhe: (...) III - julgar, mediante recurso extraordinário, as causas decididas em única ou última instância, quando a decisão recorrida: (...) b) declarar a inconstitucionalidade de tratado ou lei federal”.
} 
artigo $5^{\circ}$, acrescentado pela emenda constitucional $n^{0} 45 / 04$, tornou os tratados internacionais de direitos humanos, aprovados pelo procedimento nele previsto, “equivalentes às emendas constitucionais”, em mais uma demonstração de que esses tratados integram a ordem estatal nacional ${ }^{107}$.

O Supremo Tribunal Federal, já em 1971, sob a égide da Constituição de 1967/69, manifestou-se sobre a aplicação interna da Lei Uniforme sobre o Cheque, adotada pela Convenção de Genebra. De acordo com a ementa desse recurso extraordinário n.71.154/71, de relatoria do Ministro Oswaldo Trigueiro: "Lei Uniforme sobre Cheque, adotada pela Convenção de Genebra. Aprovada pelo Congresso Nacional, e regularmente promulgada, suas normas têm aplicação imediata, inclusive naquilo em que modificarem a legislação interna"108.

Mesmo em momento anterior, em acórdão de conflito de jurisdição relatado pelo Ministro Eloy da Rocha, em 1968, tratou-se da aplicação do direito internacional no âmbito interno, ainda que indiretamente. Deu causa à manifestação do Supremo Tribunal Federal um conflito negativo de competência com relação à aplicação, em ação executiva cambial, da Lei Uniforme sobre Letra de Câmbio e Nota Promissória, igualmente adotada pela Convenção de Genebra: para o Juiz de Direito a competência para a causa seria da Justiça Federal, por ser dessa a competência para “as causas fundadas em tratado ou contrato da União com Estado estrangeiro ou organismo internacional”, por força do artigo 125, III, da Constituição de 1967; para o Juiz Federal o direito internacional, após devidamente incorporado, “integra o direito interno nacional” e, assim, não teria o condão de alterar a competência da Justiça Estadual para a Justiça Federal ${ }^{109}$.

No caso, decidiu a Terceira Turma do Supremo Tribunal Federal que o fato de as normas a serem aplicadas no âmbito interno decorrerem do direito internacional não implica o deslocamento de sua competência original, sendo da Justiça Estadual, para a Justiça Federal $^{110}$. Em outras palavras, norma jurídica que discipline direito cambial será aplicada pela Justiça Estadual, em razão de sua competência material, independentemente de essa norma ser fundamentada em fonte interna ou em fonte internacional.

\footnotetext{
${ }^{107}$ Por força do artigo $5^{\circ}$, § $3^{\circ}$, “os tratados internacionais sobre direitos humanos que forem aprovados, em cada Casa do Congresso Nacional, em dois turnos, por três quintos dos votos dos respectivos membros, serão equivalentes às emendas constitucionais".

${ }^{108}$ Cf. recurso extraordinário $\mathrm{n}^{\circ}$ 71.154/71, p.70.

${ }^{109}$ Cf. conflito de jurisdição $n^{\circ}$ 4.663/68, p.77.

${ }^{110}$ Cf. conflito de jurisdição no ${ }^{\circ}$ 4.663/68, p.76.
} 
O que importa, todavia, apontar no julgado é que, para a discussão da aplicação da Convenção de Genebra pela Justiça Estadual ou pela Justiça Federal, tomou-se por premissa a aplicação desse direito internacional no âmbito territorial estatal, independentemente se pela Justiça Estadual ou pela Justiça Federal.

A aplicabilidade do direito internacional é acolhida da mesma maneira em decisões recentes do Supremo Tribunal Federal. Em medida cautelar em ação direta de inconstitucionalidade, julgada em 1997, consignou-se em ementa que "o iter procedimental de incorporação dos tratados internacionais - superadas as fases prévias da celebração da convenção internacional, de sua aprovação congressional e da ratificação pelo Chefe de Estado - conclui-se com a expedição, pelo Presidente da República, de decreto, de cuja edição derivam três efeitos básicos que lhe são inerentes: (a) a promulgação do tratado internacional; (b) a publicação oficial de seu texto; e (c) a executoriedade do ato internacional, que passa, então, e somente então, a vincular e a obrigar no plano do direito positivo interno" ${ }^{\text {111. }}$.

Nesse sentido, também se direciona a doutrina.

Luiz Flávio Gomes, após registrar que "é absolutamente tranqüilo entre nós o entendimento de que não é necessária a aprovação de uma lei formal para a incorporação dos tratados nos nosso ius positum", conclui no sentido de que "ratificação (ou adesão), precedida de aprovação do tratado pelo Congresso Nacional (que acontece por meio de um decreto legislativo), promulgação e publicação são as formalidades legais essenciais requeridas para que as normas internacionais possam ter vigência no Brasil”112.

Valério de Oliveira Mazzuoli, por sua vez, aduz que “os tratados internacionais ingressam no ordenamento brasileiro com vida própria, com força própria, sendo o Decreto Presidencial que os promulga a via pela qual somente se dá publicidade ao conteúdo dos tratados, fixando-lhes também o início de vigência. Não é, assim, o Decreto Presidencial, o diploma que dá validade ao tratado; seve ele tão-somente para dar-lhe publicidade e fixar o início de sua vigência”113.

\footnotetext{
${ }^{111}$ Cf. ementa ADIn n.1.480 MC-DF.

${ }^{112}$ A questão da obrigatoriedade, p.23. Não se discute, nesse momento, a necessidade de promulgação e publicação, o que se fará em momento oportuno, mas tão-somente o apontamento da aplicação das normas internacionais no Brasil.

${ }^{113}$ A opção do Judiciário brasileiro, p.117; não se discute, nessa altura, se a publicidade dos tratados internacionais de direitos humanos se dá pelo decreto executivo do Presidente da República ou pelo decreto legislativo, o que se fará em momento oportuno, mas tão-somente o fato de ser o tratado, por força própria, aplicado internamente, e não o decreto que o publica, seja ele o do Executivo ou o do Legislativo.
} 
Cândido Rangel Dinamarco, ao tratar da execução forçada, cuida das notas promissórias e das letras de câmbio, entre outros títulos executivos extrajudiciais, afirmando serem elas regidas, no direito brasileiro, pela Lei Uniforme de Genebra. A título ilustrativo, afirma Dinamarco que “a letra de câmbio, também regida pela Lei Uniforme de Genebra e em caráter subsidiário pela lei nacional (dec. n.2.044, de 31.12.1908) é uma ordem de pagamento, diferentemente da nota promissória, que é uma promessa de pagamento (...),"114.

Carlos Mário da Silva Velloso, endossando o entendimento pela aplicação do direito internacional, distingue as normas brasileiras em normas brasileiras de produção doméstica e normas brasileiras de produção internacional ${ }^{115}$.

Cabe à soberania estatal, enfim, além de determinar, em um Estado, a produção de seu próprio direito interno, autorizar a aplicação interna do direito internacional. O direito internacional é aplicado, sim, diretamente no âmbito interno, mas tão-somente na medida em que autorizado pela fonte jurídica interna, ou seja, o direito internacional pode ser aplicado diretamente pelos órgãos estatais desde que com permissão da soberania desse Estado. E tanto essa determinação da produção do direito interno quanto a autorização de aplicação do direito internacional no âmbito territorial estatal costumam estar previstas na Constituição desse Estado ${ }^{116}$.

Para Vicente Marotta Rangel, “mesmo na fase atual da evolução da sociedade internacional, o Estado continua a ser o instrumento indispensável de formação e de execução de normas convencionais. Cabe-lhe dispor sobre a maneira pela qual elabora os tratados, decidir se os considera parte integrante do ordenamento interno e determinar soluções para o conflito deles com a ordem jurídica nacional”"

Vincent Kronenberger, por sua vez, ao tratar do texto constitucional francês, aduz que "é mais razoável sugerir que direito internacional e direito doméstico são independentes entre si e que a primazia dada pela Constituição às convenções internacionais sobre a legislação doméstica, mas não sobre a própria Constituição, existe apenas porque a Constituição atribui essa superioridade»118.

\footnotetext{
${ }^{114}$ Instituições, v.4, p.265.

115 Tratados internacionais, p.29.

${ }^{116}$ Sobre as mais diversas previsões constitucionais de integração do direito internacional e daquele que é sua principal fonte, o tratado internacional, ao direito interno dos Estados, cf. Pedro Bohomoletz de Abreu Dallari, Constituição e tratados internacionais, p.20-44.

${ }^{117}$ Os conflitos entre o direito interno, p.62.

${ }^{118}$ A new approach, p.333.
} 
Ao se cuidar, assim, do procedimento de incorporação do direito internacional e, em especial, dos tratados internacionais de direitos humanos por um determinado Estado, deve-se partir, necessariamente, do seu texto constitucional. É o que se fará adiante, em capítulos próprios, tanto no estudo do direito estrangeiro, quanto na análise do caso brasileiro.

1.2.3.3. Conflitos entre normas do direito interno e normas do direito internacional e os critérios para a sua resolução.

Decorrência do item anterior é a possibilidade de conflitos entre normas de direito interno e normas de direito internacional.

Ora, se ambos os atos normativos, ainda que vinculados a fontes jurídicas distintas, podem ter o mesmo âmbito material de validade, ou seja, versar sobre matérias comuns - normas relativas a direitos fundamentais, principalmente - e podem ter o mesmo âmbito territorial de validade, levando-se em conta, obviamente, que ambos são contemporâneos - mesmo âmbito temporal -, é evidente que há a possibilidade de conflitos entre direito interno e direito internacional.

Para resolver esses conflitos, há critérios assentados, não pelo direito interno (constitucional, ou qualquer outro dos seus ramos), nem pelo direito internacional, mas, sim, pela teoria geral do direito.

Em um primeiro momento, devem-se distinguir os conflitos internos de cada ordenamento, seja ele estatal ou internacional, dos conflitos que podem ocorrer entre esses ordenamentos.

Com relação a conflitos dentro de um dado ordenamento jurídico, seja ele estatal ou internacional, apontam-se três critérios, por meio dos quais são resolvidas essas denominadas antinomias, tendo-se por resultado a revogação de uma das normas e aplicação da restante, preservando-se a coerência interna desse ordenamento: são eles o critério hierárquico, o critério cronológico e o critério da especialidade ${ }^{119}$.

119 Cf. Norberto Bobbio, Teoria do ordenamento, p.91-114. Apresenta Bobbio desdobramentos importantes, mas que, por fugir do escopo do presente trabalho, não serão analisados. São eles a ausência de critérios de resolução de antinomias, no caso de normas contemporâneas, do mesmo nível e ambas gerais (o que tange a polêmica hipótese das normas constitucionais inconstitucionais), e o conflito entre critérios (uma antinomia de segundo grau, na denominação de Bobbio, Teoria do ordenamento, p.107), na hipótese de conflito entre uma norma constitucional geral e outra infraconstitucional especial. 
Para a resolução das antinomias no direito internacional, os critérios são, em princípio, como acima assinalado, os mesmos que os critérios de resolução das antinomias no direito interno.

Há normas internacionais positivadas que prevêem critérios de resolução de antinomias. Uma dessas normas internacionais, denominadas por José Roberto Franco da Fonseca como normas de sobredireito ${ }^{120}$, a título exemplificativo, é o artigo 103 da Carta das Nações Unidas que dispõe que, "no caso de conflito entre as obrigações dos membros das Nações Unidas em virtude da presente Carta e as obrigações resultantes de qualquer outro acordo internacional, prevalecerão as obrigações assumidas em virtude da presente Carta”. Trata-se de clara previsão do critério da hierarquia: as normas da Carta das Nações Unidas são hierarquicamente superiores às demais, devendo, pois, prevalecer em caso de confronto com estas ${ }^{121}$.

Já no que tange a conflitos entre normas de ordenamentos jurídicos distintos, em especial entre normas de direito interno e normas de direito internacional, os critérios de solução de antinomias são, em princípio, os mesmos; o que varia é o tratamento dado ao direito internacional, quando aplicado no âmbito interno, pela fonte jurídica estatal na qual se fundamenta sua aplicação e o tratamento dado ao direito interno, quando aplicado no âmbito internacional, pela fonte jurídica internacional na qual se fundamenta sua aplicação.

Se o direito internacional, ao ser aplicado pelos órgãos estatais, ainda que continue sendo ato normativo internacional, tem sua aplicação autorizada pela fonte jurídica interna desse Estado, a sua posição hierárquica dentro desse ordenamento é o determinado por esse poder político soberano estatal. Por conseqüência, a aplicação de um dos critérios mencionados em caso de conflito entre normas depende, obviamente, dessa posição hierárquica.

A aplicação do critério hierárquico dependerá da posição hierárquica atribuída ao direito internacional pela fonte jurídica estatal e disso dependerá também a aplicação do critério temporal, afinal, somente se ambas as normas em conflito possuírem a mesma hierarquia dentro de um ordenamento jurídico é que se utiliza o critério temporal para saber qual delas prevalece.

\footnotetext{
${ }^{120}$ Especificidades, p.203-204, sobre as categorias de normas internacionais, que, segundo o autor, são as mesmas do direito estatal: normas programáticas, de organização, de sobredireito e de conduta.

${ }^{121}$ Há quem aponte, em razão dessa estrutura que tem assumido o direito internacional, um processo de "constitucionalização" ou de "institucionalização" do direito internacional; fenômeno que carece de estudos mais aprofundados. Cf. Celso Lafer, Comércio, p.65-88, José Carlos de Magalhães, O Supremo Tribunal Federal e o direito internacional, p.21, Vicente Marotta Rangel, Direito e relações, p.69.
} 
Já a aplicação do critério da especialidade, ainda que vinculado inicialmente ao conteúdo do próprio ato normativo, que pode ser mais genérico ou mais específico, depende principalmente da norma interna com a qual essa norma internacional será contraposta. Trata-se, pois, de critério de aplicação relativa: o caráter genérico ou específico da norma jurídica, ainda que decorra inicialmente de seu conteúdo, varia conforme a norma a ser com ela comparada. Uma norma decorrente de tratado internacional incorporado pelo Estado brasileiro, por exemplo, pode ter conteúdo claramente específico e ser tomada, em princípio, como norma específica; mas essa norma, ao ser comparada com o texto constitucional, pode encontrar nele a mesma matéria tratada de maneira ainda mais detalhada - e exemplos não são impossíveis nem pouco prováveis ${ }^{122}$. Nesse caso, deve a norma constitucional prevalecer, em aplicação do critério da especialidade $\mathrm{e}^{123}$.

Há, contudo, um critério específico, desenvolvido no seio do direito internacional, a ser levado em consideração quando se trata de conflito entre normas que versem sobre direitos humanos: a prevalência da norma mais favorável à proteção dos direitos humanos.

Na doutrina, Antônio Augusto Cançado Trindade sustenta que, "longe de operarem de modo estanque, o Direito Internacional e o direito interno passaram efetivamente a interagir, por força das disposições de tratados de direitos humanos atribuindo expressamente funções de proteção aos órgãos do Estado, assim como da abertura do Direito Constitucional contemporâneo aos direitos humanos internacionalmente consagrados. Desvencilhando-se das amarras da doutrina clássica, o primado passou a ser da norma - de origem internacional ou interna - que melhor protegesse os direitos humanos"124.

Esse critério da prevalência da norma mais favorável à proteção dos direitos humanos, seja ela a norma estatal ou a norma internacional, não deve ser tomado com toda a amplitude apresentada por Cançado Trindade. Ele não deve ser o único critério a pautar a resolução de conflitos entre direito interno e direito internacional; os demais

\footnotetext{
${ }^{122}$ Cf. Marco Antonio Corrêa Monteiro, Análise, p.718-720, em que é apontada uma série de direitos da Convenção Americana de Direitos Humanos previstos pela Constituição de 1988 de maneira mais pormenorizada e de forma mais generosa, inclusive. Adolfo Gabino Ziulu, La globalización, p.75-76, com relação à ordem jurídica argentina, aponta certas limitações e restrições a direitos e garantias constitucionais como "um aspecto menos visível" da questão da incorporação de tratados internacionais de direitos humanos, devendo esse problema ser "objeto de uma cuidadosa hermenêutica".

${ }^{123}$ Aqui ainda não se discute a aplicação do critério hierárquico.

${ }^{124}$ A proteção internacional, p.26; nesse mesmo sentido, manifesta-se o mesmo autor em seu Tratado, vol. I, p.434-436.
} 
critérios, quais sejam o hierárquico, o da especialidade e o temporal, não devem ser desconsiderados.

A aplicação do critério da norma mais favorável terá lugar se, após a utilização dos demais critérios de resolução de conflitos, restar apontada a norma de direito internacional como a que deve, em princípio, prevalecer. A identificação da norma de direito interno como a que deve prevalecer exclui a aplicação do direito internacional, pois a soberania estatal não pode ceder frente a um critério de resolução de antinomias específico, desenvolvido no seio do direito internacional.

Por outro lado, com a identificação da norma internacional como a que deve, em princípio, prevalecer, prossegue-se com o questionamento de se essa norma internacional é mais favorável à proteção dos direitos humanos em relação à norma interna. Se a norma internacional for a mais favorável, deve ela prevalecer; se a norma mais favorável for a de direito interno, deve esta prevalecer, sem que isso implique em descumprimento das obrigações estatais assumidas internacionalmente, afinal, estaria esse Estado protegendo os direitos humanos de maneira mais ampla do que a pactuada $^{125}$.

A aplicação do critério da norma mais favorável tem estreita ligação com o da otimização e maximização do sistema de proteção dos direitos humanos: caso o sistema protetivo apresentado pelo tratado internacional seja mais favorável à pessoa humana em relação à proteção garantida pela ordem estatal, aquela deve ser aplicada subsidiariamente a esta; caso a norma mais favorável seja a estatal, deve esta ser aplicada, tendo-se em vista a maximização da proteção dos direitos humanos, pois o direito internacional dispõe sobre as condições mínimas de proteção da pessoa humana, podendo, obviamente, os Estados garantir melhores condições ao indivíduo.

Como bem identificou Bidart Campos, "precisamente, a dualidade de fontes que alimenta a completude do sistema de direitos significa que, em cada caso, há que fazer opção preferencial pela fonte que proporciona a norma mais favorável à pessoa e a seus direitos, porque não obstante a aludida natureza mínima e subsidiária do direito internacional dos direitos humanos, a pauta orientadora endereça-se a lograr a otimização e maximização do sistema de direitos”126.

\footnotetext{
${ }^{125}$ Cabe, contudo, a crítica da dificuldade de determinar o que se deve entender por "norma mais favorável à proteção dos direitos humanos"; de fato, trata-se daqueles conceitos juridicamente indeterminados, que dependerá sobremaneira da atuação do intérprete.

${ }^{126}$ Tratado elemental, p.282.
} 
Por fim, há uma distinção fundamental no que concerne à sanção atribuída ao ato normativo que não prevalecer após a aplicação de qualquer dos critérios de resolução de antinomias: se no caso de conflito entre normas fundamentadas em uma mesma fonte jurídica a sanção é a revogação, no caso de conflito entre normas fundamentadas em fontes jurídicas distintas a sanção é a "suspensão da eficácia” do ato normativo que sucumbir após a aplicação de um dos critérios mencionados.

Já houve manifestação no Supremo Tribunal Federal nesse sentido. No já citado recurso extraordinário n.80.004/77, o Ministro Leitão de Abreu, ao tratar de possível conflito entre direito internacional incorporado - mais especificamente, tratado internacional - e direito interno promulgado em momento posterior, sustenta que nesse caso não se aplica o princípio lex posterior revogat priori, pois não há uma revogação "em sentido estrito": o direito interno afastaria a aplicação do tratado. Em seu voto, o Ministro afirma que, dentro da orientação a que se filia, “de que tratados-leis incidem diretamente, sem precisão de nova manifestação legislativa, que receba, formalmente, incorporando-as ao direito interno, as normas que neles figurem, não se suscita dificuldade quanto à sua eficácia de afastar a aplicação do direito nacional, naquilo em que com elas incompatível. Reconhece-se, neste particular, sem vacilações, que os tratados-leis quebram o direito local, quer se considerados a ele equiparados, quer $a$ fortiori, se a ele, sob esse aspecto, reputados superiores”127.

Esse entendimento implica, ainda pelo voto do Ministro Leitão de Abreu, em que, "se a lei revogasse o tratado, este não voltaria a aplicar-se na parte revogada, pela revogação pura e simples da lei revogatória. Mas (...) a lei não o revoga, mas simplesmente afasta, enquanto em vigor, as normas do tratado com ela incompatíveis, voltará ele a aplicar-se, se revogada a lei que impediu a aplicação das prescrições nele

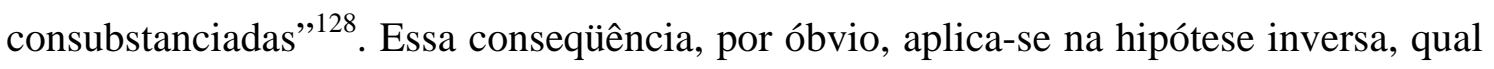
seja a da retomada de aplicação de direito interno, em razão de denúncia de tratado internacional que fora causa da suspensão de sua eficácia.

Não se discute, neste momento, a prevalência do direito interno sobre o direito internacional, ou o inverso, nas mais diversas hipóteses de conflito, mas tão-somente a idéia apresentada de que a sanção em caso de conflito entre ambos os direitos é a suspensão da eficácia - impedimento da aplicação -, e não a revogação.

\footnotetext{
${ }^{127} R E \mathrm{n}^{\mathrm{o}} 80.004 / 77, \mathrm{p} .833$.

${ }^{128} R E \mathrm{n}^{\circ} 80.004 / 77$, p.836.
} 
Carlos Mário da Silva Velloso, também Ministro do Supremo Tribunal Federal, qualificou esse voto do Ministro Leitão de Abreu como o mais importante desse julgamento $^{129}$, apontando que o entendimento nele exposto teria prevalecido em decisão ulterior do próprio Supremo ${ }^{130}$.

Em suas observações finais, conclui Velloso que, "na jurisprudência do Supremo Tribunal Federal, há paridade entre a norma brasileira de produção doméstica e a norma brasileira de produção internacional. Assim, o conflito entre uma e outra resolve-se, de regra, pelo mecanismo tradicional: lex posterior derogat legi priori. Todavia, há de se ter presente que a lei posterior não revoga o tratado anterior, 'mas simplesmente afasta, enquanto em vigor, as normas do tratado com ela incompatíveis'. Assim, revogada a lei que afastou a sua aplicação, voltará o tratado a ter aplicação"131.

Jacob Dolinger, nesse sentido, sustenta que "a melhor doutrina é a de que o tratado não é anulado nem revogado pela lei contraditória posterior, nem tampouco chega a seu termo final”, asseverando sua preferência pela afirmação de que lei interna posterior torna os tratados internacionais inaplicáveis, e não inválidos ${ }^{132}$.

Também José Francisco Rezek, ao manifestar-se sobre o recurso extraordinário n.80.004/77, afirma que "admitiram as vozes majoritárias que, faltante na Constituição

\footnotetext{
${ }^{129}$ Qualificado, igualmente por Carlos Velloso, como o julgamento mais importante sobre a matéria. Essa decisão, contudo, foi objeto de críticas, entre elas as feitas por José Carlos de Magalhães, O Supremo Tribunal Federal e as relações, p.53-57.

${ }^{130}$ Tratados internacionais, p.15-16. Segundo Carlos Mário Velloso, as Convenções de Genebra teriam sido aplicadas pelo Supremo no recurso extraordinário $n^{0}$ 95.002/81, na parte em que contrariavam o decreto-lei n ${ }^{\circ} 427 / 69$, após a revogação deste pelo decreto-lei no $1.700 / 79$. Esse entendimento pode até ter prevalecido casuisticamente nas decisões do Supremo Tribunal Federal, mas, se o que prevalece na jurisprudência desse Tribunal é a aplicação do critério lex posterior derogat legi priori, como observa nesse mesmo artigo o autor, a opinião prevalecente é, obviamente, a da revogação, e não a da suspensão da eficácia. Esse entendimento é seguido também majoritariamente na doutrina; cf. Francisco Campos, Parecer, p.452, Luiz Olavo Baptista, Inserção dos tratados, p.78, entre outros.

${ }^{131}$ Tratados internacionais, p.29.

Esse raciocínio foi o inspirador do dispositivo contido no artigo 24 da Constituição brasileira, que trata das competências legislativas concorrentes. Pelos parágrafos do artigo, à União compete editar normas gerais sobre determinadas matérias arroladas nos incisos do citado artigo. Em caso de inexistência de tal norma geral, podem os Estados exercer o que o texto constitucional denominou de competência plena, mas, por força do seu $\S 4^{\circ}$, “a superveniência de lei federal sobre normas gerais suspende a eficácia da lei estadual, no que lhe for contrário”.

O dispositivo parte do pressuposto de que os atos normativos federais e estaduais, em razão da formação e estrutura do Estado federal, fundamentam-se em fontes jurídicas distintas, não podendo, pois, uns revogarem os outros - a revogação é sanção aplicada em caso de conflito entre atos normativos fundados em uma mesma fonte jurídica.

A questão é bastante discutível. Sobre o dispositivo, observa José Afonso da Silva, Comentário, p.281: "Note-se bem, o constituinte foi técnico: a lei federal superveniente não revoga nem derroga a lei estadual no aspecto contraditório; esta apenas perde sua aplicabilidade, porque fica com sua eficácia suspensa. Quer dizer, também, que se a lei federal for simplesmente revogada, deixando um vazio de normas gerais, a lei estadual recobra sua eficácia e passa outra vez a incidir plenamente”.

${ }^{132}$ As soluções da Suprema Corte brasileira, p.79.
} 
do Brasil garantia de privilégio hierárquico do tratado internacional sobre as leis do Congresso, era inevitável que a Justiça devesse garantir a autoridade mais recente das normas, porque paritária sua estatura no ordenamento jurídico. Parecia importante, entretanto, que a decisão do Tribunal não produzisse em seus futuros analistas a idéia abstrusa de que a lei interna ulterior revoga o tratado vigente. João Leitão de Abreu foi o responsável pela exata colocação da matéria, num dos pronunciamentos mais lúcidos que o plenário da corte maior terá ouvido a propósito em toda a história”133; nesse mesmo sentido, afirma Rezek, em outro trabalho de sua autoria, que "o Congresso brasileiro não tem autoridade para revogar alguma coisa que não dependeu apenas de nossa soberania, mas envolveu outras”134. Conclui, por fim, o internacionalista que “a prova mais clara de que não há revogação é aquilo que foi teorizado no julgamento do Recurso Extraordinário $n^{\circ}$ 80.004, pelo Ministro Abreu, e que depois veio a acontecer por um capricho do acaso. Revogada que seja, aqui dentro, a lei conflitante com o tratado, este, se não foi denunciado, e justamente porque não havia sido revogado, recupera a sua inteira vigência. E a situação do País, perante os co-pactuantes lá fora, deixa de ser irregular”,

\subsubsection{A responsabilidade internacional do Estado.}

Como visto nos tópicos anteriores, o direito internacional passa a ser aplicado pelos tribunais estatais na medida em que seja incorporado ao direito interno, ou seja, na medida em que o próprio Estado, no exercício de sua soberania, autoriza a aplicação desse direito internacional em seu âmbito territorial interno.

Assume o Estado, por meio desse processo, obrigações no seio da comunidade internacional.

Acontece que os Estados podem, pelos meios mais diversos, descumprir alguma ou algumas de suas obrigações assumidas internacionalmente. Pode o Legislativo promulgar lei interna posterior contrária ao direito internacional incorporado ou pode, ainda, o Judiciário desconsiderar esse direito internacional incorporado, continuando a aplicar o direito interno anterior que lhe seja contrário. Em ambos os casos, pode o Estado ter descumprido uma obrigação assumida perante a comunidade internacional, já

\footnotetext{
${ }^{133}$ Direito dos tratados, p.472.

${ }^{134}$ Tratados e suas relações, p.55.

${ }^{135}$ Tratados e suas relações, p.56.
} 
que, para o direito internacional, não há Legislativo, Executivo ou Judiciário, mas, tãosomente, o Estado: atos do Judiciário, do Executivo ou do Legislativo, para o direito internacional, são, indistintamente, atos estatais. Assim, independentemente de qual o órgão estatal efetivamente descumpriu uma obrigação assumida, é o próprio Estado que será o responsável internacional por tal ato ${ }^{136}$.

José Francisco Rezek apresenta essa hipótese, referindo-se especificamente ao Legislativo, como uma "situação traumática”, em que os poderes políticos do Estado, esquecidos de um compromisso internacional assumido, discutem, votam e sancionam uma norma interna "incompatível com aquele dever jurídico anterior”137.

Vicente Marotta Rangel critica a tese dualista exatamente por ela não satisfazer plenamente “às exigências básicas da convivência social”, por não compatibilizar, em princípio, normas de direito interno e de direito internacional, por possibilitar aos Estados o “descumprimento de compromissos contraídos, de transgressão da palavra

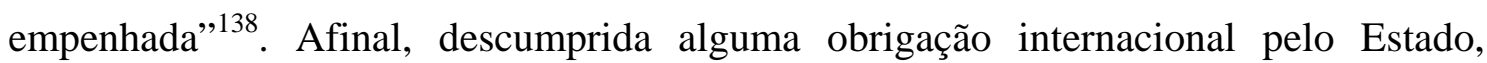
poderá ser ele sancionado pelo direito internacional. Há sanções as mais diversas: se a norma de direito internacional violada decorre do direito internacional geral ou convencional; se convencional, se a norma pertence ao sistema global ou regional; se o ofendido é um outro Estado ou se é um indivíduo; se indivíduo, se se trata de súdito do Estado violador ou de outro Estado ${ }^{139}$.

Análise detida dessas mais diversas sanções do direito internacional fugiria ao escopo do presente trabalho, mas duas observações gerais devem ser feitas sobre o tema. A primeira dela é que a guerra, meio não pacífico de solução de conflitos internacionais, deve ser entendida como a ultima ratio e merece regulamentação muito específica e cuidadosa. O segundo é que se pode perceber aqui o fenômeno, já mencionado anteriormente, da “constitucionalização" ou “institucionalização" do direito internacional, já que a aplicação de suas sanções tende a ficar cada vez mais centralizada, enfim, organizada.

\footnotetext{
${ }^{136}$ Essa é a razão pela qual a emenda constitucional no 45/04 acrescentou ao artigo 109 da Constituição o $\S 5^{\circ}$, que dispõe que, "nas hipóteses de grave violação de direitos humanos, o Procurador-Geral da República, com a finalidade de assegurar o cumprimento de obrigações decorrentes de tratados internacionais de direitos humanos dos quais o Brasil seja parte, poderá suscitar, perante o Superior Tribunal de Justiça, em qualquer fase do inquérito ou processo, incidente de deslocamento de competência para a Justiça Federal”.

${ }^{137}$ Tratados e suas relações, p.55.

${ }^{138}$ Os conflitos entre o direito interno, p.55-56.

139 Sobre a responsabilidade internacional dos Estados, cf. Guido Fernando Silva Soares, Curso, p.183200, José Carlos de Magalhães, O Supremo Tribunal Federal e o direito internacional, p.45-49.
} 


\section{ANÁliSE DA INCORPORAÇÃo E DA POSIÇÃO HIERÁRQUICA DOS TRATADOS INTERNACIONAIS DE DIREITOS HUMANOS NO DIREITO ESTRANGEIRO.}

No estágio atual do desenvolvimento humano, em que as relações inter-pessoais não mais reconhecem os limites territoriais estatais nem continentais, um estudo das relações jurídicas, ainda mais no âmbito do direito constitucional internacional, torna imprescindível a análise de como a questão é enfrentada pelo direito estrangeiro.

Nesse sentido, procura-se apontar o tratamento do tema em algumas das mais relevantes ordens jurídicas da atualidade. Serão tratadas as questões da incorporação e da posição hierárquica dos tratados internacionais, em especial os de direitos humanos, nos ordenamentos espanhol, francês, português, argentino, paraguaio e uruguaio; os três primeiros pela influência que exercem na doutrina e jurisprudência brasileiras, em razão de dispositivos relevantes que se encontram em seu texto constitucional, e os últimos pela proximidade espacial e política, em razão do Mercosul, destacando-se a influência direta da ordem constitucional argentina, após reforma de 1994.

\subsection{Espanha.}

Encontram-se, no texto constitucional, dispositivos que tratam tanto das competências para aprovação dos tratados internacionais quanto da sua posição hierárquica na ordem jurídica espanhola.

Dispõe o artigo 56 da Constituição sobre a figura do Rei da Espanha, determinando, de maneira geral, sua competência para manter relações internacionais:

Artigo 56.

1. O Rei é o Chefe de Estado, símbolo de sua unidade e permanência, arbitra e modera o funcionamento regular das instituições, assume a mais alta representação do Estado Espanhol nas relações internacionais, especialmente com as nações de sua comunidade histórica, e exerce as funções que lhe atribuem expressamente a Constituição e as leis. 
2. Seu título é o de Rei da Espanha e poderá utilizar os demais que correspondam à Coroa.

3. A pessoa do Rei é inviolável e não está sujeita a responsabilidade. Seus atos estarão sempre referendados na forma estabelecida no artigo 64, carecendo de validade sem o dito referendo, salvo o disposto no artigo 65, 2.

O artigo 63, 2, por sua vez, especifica essa competência, típica da Chefia de Estado, determinando que "ao Rei compete manifestar o consentimento do Estado para obrigar-se internacionalmente por meio de tratados, de conformidade com a Constituição e as leis”. Trata-se, assim, de competência do Chefe de Estado a negociação, assinatura e ratificação dos tratados internacionais. Essa competência, contudo, não é exercida isoladamente pelo Monarca, pois, por força do artigo 64, 1, “os atos do Rei serão referendados pelo Presidente do Governo e, se for o caso, pelos Ministros competentes"140.

O Rei da Espanha e o Presidente do Governo não celebram, porém, sozinhos um tratado internacional. O artigo 94 do texto constitucional apresenta uma lista de tratados que, para vincularem o Estado espanhol na ordem internacional, devem ser aprovados pelas Cortes Gerais; nos demais tratados internacionais, deve o Legislativo ser tãosomente informado de sua conclusão.

Determina o texto constitucional espanhol, in verbis:

Artigo 94.

1. A prestação de consentimento do Estado para obrigarse por meio de tratados ou convênios requererá a prévia autorização das Cortes Gerais, nos seguintes casos:

a) Tratados de caráter político.

b) Tratados ou convênios de caráter militar.

c) Tratados ou convênios que afetem a integridade territorial do Estado ou os direitos e deveres fundamentais estabelecidos no Título I.

\footnotetext{
${ }^{140}$ Por força do artigo 64, 1, in fine, "a proposta e a nomeação do Presidente do Governo e a dissolução prevista no artigo 99 serão referendados pelo Presidente do Congresso", determinando ainda esse mesmo artigo 64, 2, que "dos atos do Rei serão responsáveis as pessoas que os referendem”.
} 
d) Tratados ou convênios que impliquem obrigações financeiras para a Fazenda Pública.

e) Tratados ou convênios que provoquem modificação ou derrogação de alguma lei ou exijam medidas legislativas para sua execução.

2. O Congresso e o Senado serão imediatamente informados da conclusão dos restantes tratados ou convênios.

Permite-se, dessa forma, a celebração dos acordos do Executivo, ou seja, a celebração de tratados internacionais sem que haja a necessidade de consentimento do Legislativo, bastando, para vincular o Estado internacionalmente, a manifestação de vontade do Chefe de Estado, referendada pelo Chefe de Governo.

Com relação à posição hierárquica dos tratados internacionais, determina o artigo 95, 1, que "a celebração de um tratado internacional que contenha dispositivos contrários à Constituição exigirá uma previa revisão constitucional”, podendo o Governo ou qualquer das Câmaras requerer ao Tribunal Constitucional que declare se existe ou não essa contradição, o que caracteriza um típico controle de constitucionalidade preventivo ${ }^{141}$.

Têm os tratados internacionais, assim, posição hierárquica infraconstitucional, podendo igualmente a sua inconstitucionalidade ser argüida, ainda que o tratado seja incorporado sem prévia revisão constitucional, perante o Judiciário, após sua incorporação ao direito espanhol ${ }^{142}$; nem mesmo as normas advindas do direito comunitário têm posição hierárquica constitucional ${ }^{143}$. Pablo Pérez Tremps exemplifica a aplicação dessa norma constitucional com a necessidade de reforma prévia do artigo 13.2 da Constituição para a ratificação do Tratado de Maastricht, discutindo amplamente o artigo 93 do texto constitucional espanhol, inserido em um processo que o autor denominou de constitucionalização da integração e comunitarização da Constituição ${ }^{144}$.

\footnotetext{
${ }^{141}$ Cf. Luis Maria Diez-Picazo, El derecho comunitario, p.263, Albrecht Weber, El control del Tratado, p.33.

${ }_{142}$ Cf. Ricardo Alonso García, El juez, p.113-120, Luis Maria Diez-Picazo, El derecho comunitario, p.263, Albrecht Weber, El control del tratado, p.34.

${ }_{143}$ Cf. Luis Maria Diez-Picazo, El derecho comunitário, p.259-260.

${ }^{144}$ Las condiciones, p.76-80, e Constitución española; também nesse sentido, cf. Luis Maria Diez-Picazo, El derecho comunitário, p.264-265, Albrecht Weber, El control de Tratado, p.34, Joël Rideau, Les procédures, p.616, Francisco Javier Donaire Villa, El tratado de Amsterdam, p.127. Analisa Francisco Javier Donaire Villa, El tratado de Amsterdam, p.158-167, a necessidade de nova reforma da
} 
Com relação às demais leis espanholas, prevê o texto constitucional, em seu artigo 96, 1, que “os tratados internacionais validamente celebrados, uma vez publicados oficialmente na Espanha, farão parte do ordenamento interno. Suas disposições somente poderão ser derrogadas, modificadas ou suspensas na forma prevista nos próprios tratados ou de acordo com as normas gerais do Direito internacional”; segue o mesmo artigo 96, 2, prescrevendo que "para a denúncia dos tratados e convênios internacionais utilizar-se-á o mesmo procedimento previsto para sua aprovação no artigo 94”, transcrito anteriormente.

O disposto nos dois parágrafos do artigo 96 corresponde a alguns aspectos que neste trabalho se sustenta sobre a relação entre direito interno e direito internacional. Os tratados internacionais, após devidamente celebrados e incorporados, fazem parte da ordem jurídica interna, ou seja, aplicam-se por força própria e, em razão disso, somente são derrogados, modificados ou suspensos na forma prevista pelo próprio tratado, de acordo com os princípios de direito internacional. Por fim, deve o Legislativo participar do processo de denúncia de tratado internacional de que ele tenha participado da celebração.

O juiz espanhol, assim, deve aplicar o tratado internacional como se direito interno fosse, desde que não contrário à Constituição, podendo, neste caso, declarar a sua inconstitucionalidade. Deve ainda aplicar o tratado internacional, ainda que surja lei posterior a ele contrária, até que seja implementada a sua denúncia.

\subsection{França.}

No direito francês, tanto o procedimento de incorporação quanto a posição hierárquica dos tratados internacionais no direito interno são determinados pelo texto constitucional.

Dispõe o texto constitucional francês, logo em seu artigo $5^{\circ}$, que o Presidente da República "é o garante da independência nacional, da integridade do território e do respeito aos tratados”. Determina igualmente a Constituição de 1958 que é de competência do Presidente da República negociar e ratificar os tratados no âmbito internacional.

Constituição para a ratificação do Tratado de Amsterdam. Pérez Tremps, Las condiciones, p.81-85, apresenta quadro bastante interessante com os textos constitucionais alterados para a ratificação do Tratado de Maastricht na Espanha, França, Irlanda, Portugal e Alemanha. A análise do artigo 93 do texto constitucional fugiria, contudo, ao escopo do presente trabalho. 
Os artigos 52 e 53 da Constituição, interpretados conjuntamente, indicam a possibilidade da prática dos acordos do Executivo, uma vez que somente os tratados internacionais arrolados devem passar por aprovação legislativa, devendo o Presidente da República ser tão-somente informado de toda negociação tendente à conclusão de um acordo internacional não submetido à ratificação.

Faz-se necessária a transcrição desses artigos do texto constitucional francês de 1958:

Artigo 52. O Presidente da República negocia e ratifica os tratados.

Ele será informado de toda negociação tendente à conclusão de um acordo internacional não submetido à ratificação.

Artigo 53. Os tratados de paz, os tratados de comércio, os tratados ou acordos relativos à organização internacional, aqueles que envolvam as finanças do Estado, aqueles que modificam disposições de natureza legislativa, aqueles que são relativos ao estado das pessoas, aqueles que implicam em cessão, troca ou adição de território, só podem ser ratificados ou aprovados em virtude de uma lei.

Eles somente têm efeito após serem ratificados ou aprovados.

Nenhuma cessão, nenhuma troca, nenhuma adição de território será válida sem o consentimento das populações interessadas.

Mais especificamente com relação à hierarquia dos tratados internacionais, prescreve o artigo 54 da Constituição que, "se o Conselho Constitucional, provocado pelo Presidente da República, pelo Primeiro Ministro, pelo Presidente de uma ou de outra assembléia ou por sessenta deputados ou sessenta senadores, declarar que um compromisso contém uma cláusula contrária à Constituição, a autorização para ratificar ou para aprovar o compromisso internacional em questão somente pode ser dada após revisão da Constituição”. 
Está o dispositivo em conformidade com o sistema preventivo de controle de constitucionalidade francês ${ }^{145}$. Eventual conflito entre tratado e texto constitucional somente pode ser argüido em momento anterior à incorporação daquele ao direito interno, sendo a sua aprovação condicionada à revisão constitucional, que se opera por meio da votação de uma lei constitucional ${ }^{146}$. Após a incorporação do tratado não pode mais a inconstitucionalidade de tratado ser argüida, tal como não pode esse mesmo vício ser argüido em relação a nenhuma outra lei francesa, após a sua promulgação ${ }^{147}$.

Vincent Kronenberger, ao comentar o dispositivo, afirma que nele há um “tradicional silêncio” acerca da relação entre tratados internacionais e Constituição e aduz que “a interpretação do dispositivo pode levar a soluções opostas”, uma pela superioridade da Constituição, vez que “um acordo internacional não pode ser incorporado à ordem jurídica interna se ele é parcial ou totalmente incompatível com a Constituição”, e outra no sentido de que a norma não dispõe sobre a posição hierárquica de tratados, mas tão-somente disciplina uma etapa do procedimento de ratificação ${ }^{148}$.

Do exposto, contudo, pode-se extrair que, na ordem jurídica francesa, todo tratado internacional é hierarquicamente inferior à Constituição, pois não pode aquele ser aprovado enquanto esta apresentar dispositivos a ele contrários. O dispositivo constitucional, indubitável e imediatamente, disciplina o procedimento de ratificação de tratados internacionais e, de maneira mediata, determina a posição hierárquica desses tratados com relação à Constituição, atribuindo-lhe, claramente, posição infraconstitucional.

Por fim, por força do artigo 55 da Constituição, “os tratados ou acordos regularmente ratificados ou aprovados têm, desde sua publicação, hierarquia superior à das leis, sob reserva, para cada acordo ou tratado, de sua aplicação pela outra parte”.

\footnotetext{
${ }^{145}$ Cf. Louis Favoreu, Le controle, p.55-56, Albrecht Weber, El control del Tratado, p.32-33.

${ }^{146}$ Cf. Louis Favoreu, Le controle, p.43-44. Joël Rideau, Les procédures, p.617-618, descreve alterações que tiveram que ser implementadas na Constituição francesa para a ratificação do Tratado da União Européia.

${ }^{147}$ Louis Favoreu, Le controle, p.50, apresenta tão-somente três momentos em que pode ser realizado o controle de constitucionalidade de um tratado internacional: (1) após a assinatura e antes da votação da lei autorizadora de sua ratificação, (2) após a revisão constitucional exigida, para a verificação de eventual contrariedade entre o tratado internacional e a Constituição revisada e (3) após a votação da lei autorizadora de sua ratificação e antes de sua promulgação. Vincent Kronenberger, A new approach, p.335-339/354-357, por sua vez, apresenta questão interessante acerca da possibilidade de revisão, indireta e a posteriori, da validade de tratados internacionais com relação à Constituição não pelo Conselho Constitucional, mas pelo Conselho de Estado; aponta o autor decisões do Conselho de Estado nesse sentido e aponta também como tem o Conselho Constitucional reagido, para preservação de sua competência constitucional.

${ }^{148}$ A new approach, p.333.
} 
O texto constitucional é claro em atribuir hierarquia superior aos tratados internacionais com relação às leis ordinárias, condicionando esta hierarquia, no entanto, ao seu cumprimento pela outra parte. Este dispositivo cria problemas os mais diversos em sua aplicação ${ }^{149}$ e abre amplas possibilidades de descumprimento de compromissos internacionais; registra a doutrina que o dispositivo constitucional tem sido aplicado com uma certa hesitação, contrariando-se, expressamente, disposição constitucional e o princípio da superioridade do direito internacional ${ }^{150}$.

\subsection{Portugal.}

Há uma série de observações relevantes a serem feitas acerca do procedimento de incorporação dos tratados internacionais de direitos humanos ao direito interno lusitano, dada a sua influência no procedimento adotado pelo direito brasileiro.

Um primeiro aspecto desse procedimento a ser abordado é o da necessidade de aprovação desses tratados de direitos humanos pela Assembléia da República, vez que há previsão no texto constitucional português da aprovação de acordos do Executivo, para o que se dispensa a deliberação do Legislativo lusitano. Esse não é o caso dos tratados internacionais de direitos humanos. Por força do artigo $161, \mathrm{i}^{151}$, compete à Assembléia da República aprovar tratados “que versem matérias da sua competência

\footnotetext{
${ }^{149}$ Algumas destas questões são trazidas por Jacob Dolinger, As soluções, p.76: “A condicionalidade francesa é realmente uma fonte de dificuldades. Poderia o juiz, sponte propria, levantar a questão da inobservância do tratado pelo outro Estado, ou seria necessário que a parte a alegasse? O juiz teria autoridade para decidir sobre a aquiescência do outro Estado ou precisaria remeter a questão ao Ministro das Relações Exteiores? (...) E, finalmente, como aplicar o art.55 se o tratado for multilateral, ocorrendo a hipótese de não ser observado por um determinado Estado, sendo-o em outros? A doutrina e a jurisprudência francesas ainda estão por fornecer uma solução a maior parte destes problemas".

${ }^{150}$ Cf. Nguyen Quoc Dinh, Patrick Daillier, Alain Pellet, Droit, p.281 e seguintes, Vincent Kronenberger, A new approach, p.329-333, François Luchaire, Le traité d'Amsterdam, p.336. Luchaire, no trecho citado, traz decisões do Conselho Constitucional de 1992 e de 1997, em que se discutiu a condição de reciprocidade no Tratado da União Européia, em que se considerou que a exigência constitucional da reciprocidade estaria cumprida com o depósito do último instrumento de ratificação desse tratado, o que acarretaria o início de sua vigência. Essa interpretação, segundo o autor, tornaria essa exigência constitucional mais formal do que material, permitindo engajamentos diferentes de um Estado a outro, em razão de um único tratado multilateral; exemplifica Luchaire essa situação com o próprio tratado de Amsterdã, que contém disposições especificas para a Dinamarca, Irlanda, Grã-Bretanha, Alemanha e Itália. Conclui o autor afirmando que a exigência da reciprocidade poderia ser utilizada para se opor à aplicação de um tratado que crie situação de grande desequilíbrio em desfavor da República francesa.

151 “Artigo 161. Competência política e legislativa. Compete à Assembléia da República: (...) i) Aprovar os tratados, designadamente os tratados de participação de Portugal em organizações internacionais, os tratados de amizade, de paz, de defesa, de retificação de fronteiras e os respeitantes a assuntos militares, bem como os acordos internacionais que versem matérias da sua competência reservada ou que o Governo entenda submeter à sua apreciação".
} 
reservada”, dentre as quais, conforme disposto no artigo $165,1, \mathrm{~b}^{152}$, encontra-se a legislação sobre “direitos, liberdades e garantias”.

Devem, pois, os tratados internacionais de direitos humanos passar pela aprovação da Assembléia da República para que possam ser ratificados pelo Presidente da República. É o que dispõe o artigo 135, $b^{153}$, do texto constitucional português, por força do qual cabe ao Presidente da República, após aprovação da Assembléia da República, ratificar os tratados internacionais. Incluem-se, aqui, assim, os tratados internacionais de direitos humanos.

Cabe ainda ao Presidente da República, após ratificar o tratado no âmbito do direito internacional, publicá-lo no Diário da República, para que o tratado possa ser aplicado pelos órgãos estatais. Somente após a sua publicação oficial e enquanto vincular internacionalmente o Estado português vigora o tratado internacional na ordem interna portuguesa, fazendo parte de seu direito estatal (artigo $8^{\circ}$, inciso $2^{154}$, artigo 119 , inciso 1 , alínea $\mathrm{b}^{155}$, e artigo 134, alínea $\mathrm{b}^{156}$, da Constituição) ${ }^{157}$.

Incorporados ao direito interno, cabe questionar qual é a posição hierárquica ocupada pelos tratados internacionais de direitos humanos na ordem interna portuguesa, tarefa dificultada pelo fato de inexistir dispositivo constitucional expresso nesse sentido, como há na Constituição argentina, por exemplo. Dessa forma, coube à doutrina e à jurisprudência determinar qual a posição ocupada por esses tratados no direito interno português.

152 “Artigo 165. Reserva relativa de competência legislativa. 1. É da exclusiva competência da Assembléia da República legislar sobre as seguintes matérias, salvo autorização ao Governo: (...) b) Direitos, liberdades e garantias".

153 “Artigo 135. Competência nas relações internacionais. Compete ao Presidente da República, nas relações internacionais: a) Nomear os embaixadores e os enviados extraordinários, sob proposta do Governo, e acreditar os representantes diplomáticos estrangeiros; b) Ratificar os tratados internacionais, depois de devidamente aprovados; c) Declarar a guerra em caso de agressão efetiva ou iminente e fazer a paz, sob proposta do Governo, ouvido o Conselho de Estado e mediante autorização da Assembléia da República, ou, quando esta não estiver reunida nem for possível a sua reunião imediata, da sua Comissão Permanente".

154 “Artigo 80. Direito internacional. (...) 2. As normas constantes de convenções internacionais regularmente ratificadas ou aprovadas vigoram na ordem interna após a sua publicação oficial e enquanto vincularem internacionalmente o Estado Português”.

155 “Artigo 119. Publicidade dos atos. 1. São publicados no jornal oficial, Diário da República: (...) b) As convenções internacionais e os respectivos avisos de ratificação, bem como os restantes avisos a elas respeitantes”.

156 “Artigo 134. Competência para prática de atos próprios. Compete ao Presidente da República, na prática de atos próprios: (...) b) promulgar e mandar publicar as leis, os decretos-leis e os decretos regulamentares, assinar as resoluções da Assembléia da República que aprovem acordos internacionais e os restantes decretos do Governo”.

157 É inspirado nessa tradição lusitana que o Supremo Tribunal Federal brasileiro, ao menos desde o Recurso Extraordinário n. 71.154 de 1971, apesar da inexistência de dispositivo constitucional brasileiro expresso como o português, entende ser necessária a promulgação e a publicação dos tratados internacionais, inclusive os de direitos humanos, por meio de decreto do Presidente da República. 
Em um primeiro momento, deve-se discutir qual a relação existente entre os tratados de direitos humanos e a Constituição portuguesa de 1976. Sobre essa relação, aduz Jorge Miranda que “não parece justificarem-se quaisquer dúvidas sobre o modo como no Direito português se posicionam as normas constantes de tratados internacionais perante a Constituição: posicionam-se numa relação de subordinação”, e segue o autor fundamentando que "para lá de todos os argumentos de caráter geral que possam ser retirados do princípio da soberania ou da independência nacional [preâmbulo e artigos $1^{\circ}$ e $9^{\circ}$, alínea b], bastaria lembrar a sujeição de tais normas à fiscalização da constitucionalidade, se bem que com especificidades significativas (artigos 277, inciso 2, 278, inciso 1, 279, inciso 4, e 280, inciso 3)"158.

Pode-se concluir, pois, que os tratados internacionais incorporados ao direito interno português não têm hierarquia constitucional, vez que podem ter a sua inconstitucionalidade declarada, o que pressupõe posição hierárquica inferior desses tratados, objetos do controle de constitucionalidade, com relação à Constituição portuguesa, parâmetro desse controle ${ }^{159}$.

Apontada a hierarquia infraconstitucional dos tratados internacionais de direitos humanos, deve-se verificar a sua relação com as normas internas ordinárias. Gomes Canotilho afirma ser problemática essa questão da posição hierárquica do direito internacional convencional no sistema português das fontes de direito, “dividindo-se a doutrina entre duas posições fundamentais: (1) valor infraconstitucional mas supralegislativo do direito internacional convencional; (2) paridade hierárquiconormativa entre as normas convencionais internacionais e os atos legislativos internos”, para, enfim, posicionar-se no sentido de que “a paridade hierárquico-normativa, ou seja,

\footnotetext{
${ }^{158}$ As relações, p.141. Vale transcrever alguns incisos dos artigos 277 e 278 da Constituição lusitana, que tratam da inconstitucionalidade por ação e da fiscalização preventiva da constitucionalidade: “Artigo 277. Inconstitucionalidade por ação. 1. São inconstitucionais as normas que infrinjam o disposto na Constituição ou os princípios nela consagrados. 2. A inconstitucionalidade orgânica ou formal de tratados internacionais regularmente ratificados não impede a aplicação das suas normas na ordem jurídica portuguesa, desde que tais normas sejam aplicadas na ordem jurídica da outra parte, salvo se tal inconstitucionalidade resultar de violação de uma disposição fundamental. Artigo 278. Fiscalização preventiva da constitucionalidade. 1. O Presidente da República pode requerer ao Tribunal Constitucional a apreciação preventiva da constitucionalidade de qualquer norma constante de tratado internacional que lhe tenha sido submetido para ratificação, de decreto que the tenha sido enviado para promulgação com lei ou como decreto-lei ou de acordo internacional cujo decreto de aprovação lhe tenha sido remetido para assinatura. (...) 3. A apreciação preventiva da constitucionalidade deve ser requerida no prazo de oito dias a contar da data da recepção do diploma. (...) 8. O Tribunal Constitucional deve pronunciar-se no prazo de vinte e cinco dias, o qual, no caso no n. 1, pode ser encurtado pelo Presidente da República, por motivo de urgência".

159 Trata-se do mesmo raciocínio utilizado por parte da doutrina e pela jurisprudência do Supremo Tribunal Federal, sobretudo antes das alterações promovidas pela emenda constitucional n. 45/04, com relação ao artigo 102, III, b, da Constituição brasileira de 1988.
} 
o valor legislativo ordinário das convenções internacionais deve rejeitar-se pelo menos nos casos de convenções de conteúdo materialmente constitucional (exs: Convenção Européia dos Direitos do Homem, Pacto Internacional sobre direitos civis e políticos e Pacto Internacional sobre direitos econômicos, sociais e culturais)”160.

Jorge Miranda, no mesmo sentido, sustenta que direito internacional convencional posterior prevalece sobre o direito interno ordinário português. Contudo, “algumas dificuldades só podem ter que ver com a relação entre Direito internacional convencional anterior e Direito ordinário posterior, ainda que também aqui a larga maioria da doutrina se pronuncie a favor da supremacia e, portanto, da inderrogabilidade do primeiro"161. Conclui o constitucionalista da Universidade de Lisboa que "sempre temos defendido e continuamos a defender que todas as normas internacionais vinculadas de Portugal prevalecem sobre as normas legais, sejam anteriores ou posteriores" ${ }^{\prime 162}$.

Entende, assim, a doutrina, apesar da inexistência de dispositivo constitucional expresso, gozarem os tratados internacionais de direitos humanos de posição hierárquica infraconstitucional, porém, supralegal.

\subsection{Argentina.}

A Constituição argentina de 1853, após reforma realizada em 22 de agosto de 1994, passou a dispor expressamente sobre a incorporação e sobre a posição hierárquica dos tratados de direitos humanos em sua ordem interna ${ }^{163}$.

Até a reforma, a doutrina e a jurisprudência procuravam apontar a posição hierárquica desses tratados partindo-se da interpretação do artigo 31 do texto constitucional, que dispunha - e ainda dispõe - que “esta Constituição, as leis da Nação que em sua conseqüência se ditem pelo Congresso e os tratados com as potências estrangeiras são a lei suprema da Nação (...)”.

A interpretação dada inicialmente ao dispositivo pelos tribunais argentinos seguiu o entendimento dado pela Suprema Corte norte-americana ao artigo VI da Constituição de 1787, no sentido de que a Constituição prevalece sobre leis e tratados,

\footnotetext{
${ }^{160}$ Direito constitucional, p.821.

${ }^{161}$ As relações, p.146. Em nota, menciona Jorge Miranda uma série de autores, tais como João de Castro Mendes Rui Moura Ramos e Mota Campos.

${ }^{162}$ As relações, p.147.

${ }^{163}$ Para uma visão geral sobre a reforma, cf. Fabián Salvioli, La Constitución, p.10-29.
} 
não existindo, na falta de fundamento normativo, hierarquia entre esses últimos: leis internas e tratados têm a mesma hierarquia, aplicando-se os critérios clássicos de solução de antinomias - hierarquia, especialidade e temporal - no caso de conflito entre eles.

Firmou-se esse entendimento especialmente a partir do caso Martín y Cia S.A. c/ Administración General de Puertos, julgado pela Corte Suprema em 1963, caso esse que, segundo Ernesto J. Rey Caro, dividiu os publicistas e criou um critério “questionável”, que entraria em contradição com a Convenção de Viena de 1969, em vigor na Argentina desde $1980^{164}$. Em razão de intensa manifestação da doutrina e de inúmeras decisões dos juízos de primeiro grau, a Suprema Corte abandonou esse entendimento. No caso Ekmekdjian, Miguel Angel c/ Sofovich Geraldo e outros, decidiu a Corte Suprema que, por força do artigo 27 da Convenção de Viena ${ }^{165}$, não poderia o Estado argentino descumprir tratado internacional em razão da publicação de lei interna a ele contrária ${ }^{166}$. Foi, todavia, somente com a reforma de 1994 que se colocou um ponto final na questão ${ }^{167}$.

Com a reforma, pois, sistematizou-se a tratamento constitucional sobre a incorporação e sobre a posição hierárquica dos tratados internacionais de direitos humanos na ordem estatal argentina.

Sobre a incorporação dos tratados internacionais em geral, dentre os quais os de direitos humanos, dispõe o texto constitucional, em seu artigo 99, inciso 11, ser atribuição do Presidente da Nação “concluir e firmar tratados, concordatas e outras negociações requeridas para a manutenção de boas relações com as organizações internacionais e as nações estrangeiras”. Assim como no Estado brasileiro, cabe ao Presidente da Nação argentina manter relações com os Estados estrangeiros, por meio de tratados que estejam em conformidade com os princípios de direito público estabelecidos na Constituição (artigo 27 da Constituição argentina).

Essa atribuição, contudo, assim como no Estado brasileiro, deve ser exercida em conjunto com o Poder Legislativo. É o que está disposto no artigo 75, inciso 22, do texto constitucional. Esse dispositivo merece algumas considerações com relação ao

\footnotetext{
${ }^{164}$ Los tratados internacionales, p.211.

165 “Artigo 27. Direito interno e observância dos tratados. Uma parte não pode invocar as disposições de seu direito interno para justificar o inadimplemento de um tratado (...)”. Para a análise de alguns argumentos fundados na Convenção de Viena, cf. Rodrigo de Alencar Mascarenhas, O conflito, p.79-81. ${ }^{166}$ Cf. Ernesto J. Rey Caro, Los tratados internacionales, p.219-220.

${ }^{167}$ Para uma visão geral das fases da jurisprudência da Suprema Corte argentina, cf. Ernesto J. Rey Caro, Los tratados internacionales, p.211-223.
} 
procedimento de incorporação e à posição hierárquica dos tratados internacionais de direitos humanos na ordem jurídica argentina.

Dispõe o artigo 75, inciso 22, do texto constitucional, in verbis:

Artigo 75. Compete ao Congresso:

22. Aprovar ou recusar tratados concluídos com as demais nações e com as organizações internacionais e as concordatas com a Santa Sé. Os tratados e as concordatas têm hierarquia superior às leis.

A Declaração Americana dos Direitos e Deveres do Homem; a Declaração Universal de Direitos Humanos; a Convenção Americana sobre Direitos Humanos; o Pacto Internacional de Direitos Econômicos, Sociais e Culturais; o Pacto Internacional de Direitos Civis e Políticos e seu Protocolo Facultativo; a Convenção sobre a Prevenção e a Repressão do Crime de Genocídio; a Convenção Internacional sobre a Eliminação de todas as Formas de Discriminação Racial; a Convenção Internacional sobre a Eliminação de todas as Formas de Discriminação contra a Mulher; a Convenção contra a Tortura e outros Tratamentos ou Penas Cruéis, Desumanas ou Degradantes; a Convenção sobre os Direitos das Crianças; nas condições de sua vigência, têm hierarquia constitucional, não derrogam nenhum artigo da primeira parte desta Constituição e devem entender-se complementares aos direitos e garantias por ela reconhecidos. Somente poderão ser denunciados, se for o caso, pelo Poder Executivo nacional, com prévia aprovação de dois terços da totalidade dos membros de cada Câmara.

Os demais tratados e convenções sobre direitos humanos, ao serem aprovados pelo Congresso, necessitarão do voto de dois terços da totalidade dos membros de cada Câmara para gozar de hierarquia constitucional.

No que tange ao procedimento de incorporação, como acima já se mencionou, o Presidente da Nação Argentina somente pode ratificar um tratado internacional, ainda 
que de direitos humanos, após a sua aprovação pelo Congresso; não cabe exclusivamente a ele o trato com os Estados estrangeiros. Assim também é no direito brasileiro, vez que o Presidente da República, por força dos artigos 49, I, e 84, VIII, da Constituição, somente pode ratificar um tratado internacional após ser ele aprovado pelo Congresso Nacional.

Não é, contudo, a aprovação do tratado pelo Congresso que vincula o Estado argentino internacionalmente, mas, sim, a sua ratificação pelo Poder Executivo. Nesse sentido, Bidart Campos afirma que "a incorporação dos tratados ao direito argentino não se opera com a aprovação que deles faz o congresso (...) senão com a ratificação que efetua o poder executivo em sede internacional" ${ }^{168}$.

É, assim, atribuição do Presidente da Nação a manutenção das relações com outros Estados no âmbito do direito internacional, celebrando tratados, concordatas e outras negociações, ainda que o exercício dessa atribuição constitucional seja condicionado à atuação do Legislativo.

No que diz respeito à posição hierárquica dos tratados internacionais de direitos humanos, a reforma constitucional de 1994 solucionou a discussão que vinha sendo travada pela doutrina e pela jurisprudência argentinas. O novo texto constitucional atribuiu expressamente hierarquia constitucional a onze atos normativos internacionais $^{169}$ já incorporados à época da reforma, bem como determinou a possibilidade de outros adquirirem a mesma posição hierárquica, desde que aprovados pelo voto de dois terços da totalidade dos membros de cada Câmara.

A Constituição de 1853, a partir da reforma de 1994, deixou de ser o único documento normativo a gozar de hierarquia constitucional na ordem jurídica argentina. Os tratados internacionais indicados expressamente pelo artigo 75 , inciso 22 , bem como os demais tratados de direitos humanos que forem aprovados pelo procedimento indicado pelo mesmo dispositivo constitucional, passaram a compor, somados à Constituição de 1853, o que a doutrina denomina bloco de constitucionalidade. Esses tratados internacionais, assim, não integram o documento constitucional, alterando seu texto, mas integram o direito argentino, devendo ser aplicados pelos órgãos estatais

\footnotetext{
168 Tratado elemental, p.284.

169 Tratados, mas também declarações, às quais tradicionalmente não se atribui força normativa; para uma análise dos pactos internacionais, cf. Graciela R. Salas, Los pactos internacionales, e para uma análise dos documentos regionais mencionados no dispositivo, cf. Zlata Drnas de Clément, Los documentos internacionales.
} 
como qualquer outro ato normativo interno, ainda que conserve a sua natureza de direito internacional, com fundamento nessa fonte externa.

Nesse sentido tem julgado a Corte Suprema de Justiça argentina. No caso Maria Graciela Dieser y Carlos Andrés Fraticelli, julgado em 8 de agosto de 2006, em que se discutiu a garantia da imparcialidade e o devido processo legal, decidiu-se que a garantia do juiz imparcial, reconhecida dentro dos direitos implícitos do texto constitucional, pois deriva "das garantias do devido processo e da defesa em juízo estabelecidas no artigo 18 da Constituição Nacional e consagrada expressamente nos artigos 26 da Declaração Americana dos Direitos e Deveres do Homem, 14.1 do Pacto Internacional de Direitos Civis e Políticos, 8.1 da Convenção Americana sobre Direitos Humanos, 10 da Declaração Universal de Direitos Humanos (que formam parte do bloco de constitucionalidade federal em virtude da incorporação expressa que efetua o artigo 75, inciso 22, da Constituição Nacional)”"170.

Igualmente manifestou-se a Corte Suprema de Justiça sobre a hierarquia constitucional dos tratados internacionais de direitos humanos no caso Luis Ledesma c/ Provincia de Santiago Del Estero, julgado em 11 de julho de 2006, no qual ficou assentado que "o hospital público é uma conseqüência direta do imperativo constitucional que põe a cargo do Estado a função transcendental da prestação dos serviços de saúde em condições tais de garantir a proteção integral do ser humano, destinatário essencial dos direitos reconhecidos pela Constituição e por diversos tratados internacionais com igual hierarquia, entre os quais se encontra o direito à saúde (artigos 14, bis, 33 e 75, inciso 22, da Constituição Nacional)”171.

German J. Bidart Campos, sobre o dispositivo constitucional em discussão, afirma que “a) os instrumentos internacionais que invistam hierarquia constitucional estão incorporados ao direito argentino mas não à constituição; b) é a fonte internacional a que dá origem a sua normativa, que uma vez ingressada ao direito interno conserva sua natureza de normativa internacional dentro dele; c) a hierarquia constitucional dos instrumentos a que alude o artigo 75 inciso 22 provém da constituição, mas carece do alcance de fazê-los formar parte dela, ou de produzir a novação da normativa internacional em normativa oriunda do direito interno; d) os

${ }^{170}$ Corte Suprema de Justicia de la Nación - Argentina. Maria Graciela Dieser y Carlos Andrés Fraticelli, s/ homicidio calificado por el vínculo y por alevosia, in www.csjn.gov.ar, acesso em 29 de dezembro de 2006. Causa n. 120/02, julgada em 8 de agosto de 2006.

${ }^{171}$ Corte Suprema de Justicia de la Nación - Argentina. Luis Ledesma c/ Provincia de Santiago del Estero, s/ daños y perjuicios, in www.csjn.gov.ar, acesso em 29 de dezembro de 2006. Causa julgada em 11 de julho de 2006. 
instrumentos internacionais com hierarquia constitucional integram, fora da constituição, mas com seu mesmo nível, o bloco de constitucionalidade federal"172.

Ainda uma questão deve ser discutida com relação ao artigo 75, inciso 22, acrescentado pela reforma de 1994, quando interpretado esse dispositivo sistematicamente com o artigo 27 igualmente da Constituição. Prescreve aquele dispositivo que os tratados internacionais de direitos humanos têm hierarquia constitucional, mas "não derrogam nenhum artigo da primeira parte desta Constituição e devem entender-se complementares aos direitos e garantias por ela reconhecidos”, ao passo que o último autoriza o Presidente da Nação argentina manter relações com os Estados estrangeiros, por meio de tratados que estejam em conformidade com os princípios de direito público estabelecidos na Constituição.

Coloca-se, assim, em dúvida a hierarquia constitucional desses tratados de direitos humanos, pois, se esses tratados não podem derrogar nenhum artigo da primeira parte da Constituição, entre eles o próprio artigo 27, não haveria verdadeira hierarquia constitucional desses tratados, pois eles não poderiam contrariar os princípios de direito público estabelecidos pela própria Constituição. Ademais, o mesmo artigo 75, inciso 22, estabelece que os tratados de direitos humanos devem entender-se complementares aos direitos e garantias reconhecidas pelo próprio texto constitucional; essa complementariedade reforçaria a idéia de que os tratados internacionais de direitos humanos gozariam de uma hierarquia constitucional de segunda classe.

Adolfo Gabino Ziulu e Fernando Corrêa Martins sustentam, por outro lado, que não deve ser esse o entendimento mais adequado. Para os autores, deve-se entender, sim, que os dispositivos trazidos pelos tratados internacionais de direitos humanos, por gozarem da mesma hierarquia constitucional do restante da Constituição, devem ser interpretados de maneira a formarem um todo harmônico, o que representa um dos pilares da clássica interpretação normativa constitucional que é o princípio da unidade da Constituição ${ }^{173}$.

As análises tratam, todavia, de objetos distintos, confundindo ato veiculador de norma e dispositivo veiculado. Tratados internacionais de direitos humanos, incorporados nos termos do artigo 75, inciso 22, não podem revogar nenhum artigo da primeira parte da Constituição, pois estes artigos são expressão do Poder Constituinte

172 Tratado elemental, p.285. Também sobre o tema, cf. José Miguel Onaindia, Bloque de constitucionalidad.

${ }^{173}$ Cf. Adolfo Gabino Ziulu, La globalización, p.74, Fernando Corrêa Martins, Emendas constitucionais, p.52-53. 
Originário e os tratados são expressão do Poder Constituinte Derivado. Nesse momento, devem ser os tratados internacionais submetidos ao controle de constitucionalidade, como ocorre igualmente com as emendas à Constituição. Após, uma vez incorporado o tratado internacional, as normas por ele veiculadas têm posição hierárquica constitucional e passam a ser parâmetro para o controle de constitucionalidade (com relação a normas infraconstitucionais e a normas ulteriores de emenda ou de revisão constitucional, mas, com relação a normas constitucionais anteriores a sua incorporação, continuam a ser objeto desse controle). Nesse momento, sim, essas normas "devem entender-se complementares aos direitos e garantias” já reconhecidos pelo texto constitucional, podendo-se, então, falar em interpretação sistemática.

Os tratados internacionais de direitos humanos no direito argentino, em resumo, devem obedecer a um procedimento de incorporação, que, na prática, confunde-se com o procedimento de celebração do próprio tratado, pois se encerra com a ratificação do tratado pelo Presidente da Nação. Esses tratados de direitos humanos têm posição hierárquica constitucional por determinação expressa do texto constitucional ou podem ser incorporados com essa posição hierárquica, desde que observado o procedimento indicado pelo texto constitucional. Os demais tratados internacionais - os que não versem sobre direitos humanos ou os que versem sobre direitos humanos, mas não estejam previstos expressamente no rol do artigo 75, inciso 22, nem tenham alcançado o quorun específico de votação do mesmo dispositivo - têm posição hierárquica infraconstitucional, mas hierarquia superior à das leis (artigo 75, inciso 22, primeira parte, da Constituição argentina, que tem conteúdo residual e alcance amplo ${ }^{174}$ ).

Pode-se, por fim, observar que a questão da incorporação e, principalmente, a da hierarquia dos tratados internacionais de direitos humanos foi resolvida de maneira mais adequada no ordenamento jurídico argentino, pela reforma de 1994, quando comparada com a solução dada pela reforma de 2004 no direito interno brasileiro ${ }^{175}$. Segundo Adolfo Gabino Ziulu, a República Argentina, com a reforma de 1994, passou a integrar o grupo de países que adequaram sua Lei Fundamental “para outorgar melhor acolhida

\footnotetext{
${ }^{174}$ Cf. Adolfo Gabino Ziulu, La globalización, p.69.

175 Isso porque, nas palavras de Pedro de Abreu Dallari, Tratados internacionais, p.90, "a fonte de inspiração desse novo preceito parece residir fundamentalmente no texto constitucional argentino", seguido por Maria Paula Alves de Souza, Integração dos tratados, p.46, para quem "a intenção inicial de inclusão do dispositivo analisado foi dar tratamento à matéria seguindo o exemplo da Argentina”.
} 
ao direito internacional e ao processo de integração regional”176, posicionamento igualmente adotado por Fabián Salvioli ${ }^{177}$.

No direito argentino, não há discussão com relação à posição hierárquica dos tratados internacionais de direitos humanos aprovados em data anterior à reforma constitucional; não há discussão também com relação à hierarquia dos demais tratados internacionais, pois eles foram contemplados expressamente pelo texto constitucional que lhes atribuiu posição supralegal; também não há dúvidas com relação ao procedimento de denúncia desses tratados, vez que prevista a necessidade de prévia aprovação de dois terços da totalidade dos membros de cada Câmara. Na opinião de Ernesto J. Rey Caros, “o acerto dos constituintes é inegável. A clara solução constitucional evitará no futuro que uma questão tão transcendente como a da hierarquia dos tratados e acordos internacionais deixe de depender de uma interpretação judicial"178.

Tais dispositivos constitucionais, sem dúvidas, facilitam a inserção do Estado argentino no cenário internacional. A reforma constitucional argentina, implementada dez anos antes da brasileira, deveria ter sido levada em consideração.

\subsection{Paraguai.}

Na ordem jurídico-constitucional paraguaia, assim como na brasileira, cabe ao Presidente da República celebrar tratados internacionais, desde que aprovados pelo Congresso (artigos 202, inciso $9^{179}, 224$, inciso $1^{180}$, 238, inciso $7^{181}$, da Constituição).

A participação da Câmara de Senadores é expressa no texto constitucional, já a participação da Câmara de Deputados decorre de maneira mediata do artigo 209, inciso 9, que atribui ao Congresso - e não somente à Câmara de Senadores - "aprovar ou rejeitar os tratados e demais acordos internacionais subscritos pelo Poder Executivo”. Da interpretação de ambos os dispositivos constitucionais conclui-se que cabe à Câmara

\footnotetext{
${ }^{176}$ La globalización, p.63.

${ }^{177}$ La Constitución, p.15-16.

${ }^{178}$ Los tratados internacionales, p.223.

179 “Artigo 202. Dos deveres e das atribuições. São deveres e atribuições do Congresso: (...) 9. Aprovar ou rejeitar os tratados e demais acordos internacionais subscritos pelo Poder Executivo”.

180 “Artigo 224. Das atribuições exclusivas da Câmara de Senadores. São atribuições exclusivas da Câmara de Senadores: 1. Iniciar a consideração dos projetos de lei relativos à aprovação de tratados e acordos internacionais”.

181 “Artigo 238. Dos deveres e das atribuições do Presidente da República. São deveres e atribuições de quem exerce a Presidência da República: 7. (...) Negociar e assinar tratados internacionais (...)”.
} 
de Senadores iniciar o procedimento de aprovação dos tratados internacionais, inclusive os de direitos humanos, atuando a Câmara de Deputados como uma câmara revisora, “seguindo assim o procedimento de formação e sanção de leis estipulado no texto constitucional” ${ }^{\prime 182}$.

A autorização para o Presidente ratificar tratados, vinculando o Estado paraguaio no cenário internacional, depende, como decorre do próprio texto constitucional, da aprovação de um projeto de lei pelo Congresso. A aprovação desse projeto de lei não implica, contudo, na não aplicação direta do tratado internacional pelos órgãos estatais paraguaios; não se trata aqui da aplicação de um dualismo "extremado”. Um tribunal nacional, por exemplo, pode aplicar normas de direitos humanos de caráter internacional, vez que o próprio texto constitucional previu os tratados internacionais como integrantes do direito positivo nacional paraguaio (artigo 137 da Constituição) ${ }^{183}$.

Dispõe esse dispositivo constitucional sobre a supremacia da Constituição, prescrevendo que “a lei suprema da República é a Constituição. Esta, os tratados, convênios e acordos internacionais aprovados e ratificados, as leis ditadas pelo Congresso e outras disposições jurídicas de inferior hierarquia, sancionadas em conseqüência, integram o direito positivo nacional na ordem de preleção anunciada $(\ldots)$ ".

A lei aprovada pelo Congresso é, pois, uma autorização constitucionalmente necessária para que o Poder Executivo possa ratificar o tratado no âmbito internacional, possibilitando a sua aplicação de maneira direta pelos órgãos estatais, da mesma maneira que qualquer outro ato normativo de produção exclusivamente interna.

Incorporado o tratado internacional ao direito interno paraguaio, passa-se ao questionamento sobre sua posição hierárquica dentro desse ordenamento. A resposta está no artigo 137 da Constituição, que estipula tanto a supremacia normativa da Constituição quanto a prevalência hierárquica dos tratados, convênios e acordos internacionais aprovados e ratificados com relação às leis internas.

Segundo Maria Elodia Almirón Prujel, “tem-se em primeiro lugar a Constituição como norma suprema e fundamentadora da ordem positiva interna paraguaia, que prescreve a ordem de preleção e importância na aplicabilidade da ordem jurídica interna; em segundo lugar, as normas de caráter internacional que devem cumprir um requisito prévio, consistente na aprovação e ratificação pelo Congresso Nacional e pelo

\footnotetext{
${ }^{182}$ Cf. María Elodia Almirón Prujel, Los derechos humanos, p.36.

${ }^{183}$ Cf. María Elodia Almirón Prujel, Los derechos humanos, p.30.
} 
Poder Executivo; e logo as leis ditadas pelo Congresso Nacional e outras disposições jurídicas de inferior hierarquia”184. Alejandro Piera, por sua vez, afirma taxativamente que o artigo 137, “fundamental no direito constitucional paraguaio, claramente estabelece supremacia da Carta Magna sobre qualquer outra norma”185, comentando, em seguida, que os tratados internacionais devidamente ratificados estão em situação de primazia com relação às normas de direito positivo interno, situação que tem sido confirmada pelos tribunais.

Os tratados internacionais de direitos humanos, contudo, por força do artigo 142 do texto constitucional, somente podem ser denunciados pelo mesmo procedimento previsto para a aprovação de emendas constitucionais. Dispõe esse dispositivo constitucional que "os tratados internacionais relativos aos direitos humanos não poderão ser denunciados senão pelos procedimentos que regem a emenda desta Constituição".

Com fundamento nesse artigo, poder-se-ia sustentar a posição hierárquica constitucional desses tratados internacionais. É o que afirma Cynthia González Feldmann, para quem “a Constituição do Paraguai no artigo 142 equiparou a sua própria hierarquia, ao menos quando à estabilidade se refere, os tratados relativos a direitos humanos, já que eles não poderão ser denunciados senão pelos procedimentos que regem para a emenda da Constituição"186.

Não parece ser essa, todavia, a melhor interpretação do texto constitucional. O artigo 137, comentado anteriormente, estabelece a ordem hierárquica entre Constituição, tratados internacionais e leis internas. A determinação pelo texto constitucional de um procedimento mais dificultoso para a denúncia dos tratados internacionais de direitos humanos em nada deve influenciar na determinação de sua posição hierárquica: uma maior estabilidade nos compromissos estabelecidos pelo Estado paraguaio no cenário internacional, especificamente no que concerne à proteção dos direitos humanos, pode ser garantida pela exigência qualificada da denúncia desses tratados, ainda que eles não gozem de hierarquia constitucional enquanto aplicados no âmbito territorial estatal ${ }^{187}$.

\footnotetext{
${ }^{184}$ Los derechos humanos, p.35. Igualmente o artigo 141 do texto constitucional paraguaio declara que esses tratados internacionais formam parte do ordenamento interno e determina a sua posição hierárquica.

${ }^{185}$ La incorporación, p.88.

${ }^{186}$ La implementación, p.20.

${ }^{187}$ Cf. Fátima Andrada, El Paraguay, p.48.
} 
No direito paraguaio, em resumo, os tratados internacionais de direitos humanos devem passar por um procedimento de incorporação para o qual concorrem Executivo e Legislativo, assim como no direito brasileiro. Têm esses tratado posição hierárquica “quase-constitucional”188, pois de hierarquia inferior à Constituição mas superior à das leis internas; ademais, para que possam ser denunciados, deve ser obedecido o mesmo procedimento de emenda à Constituição.

\subsection{Uruguai.}

Poucas são as referências aos tratados internacionais na Constituição da República Oriental do Uruguai de 1967. Nesse sentido, já observou Pedro Dallari que “o Uruguai, por sua vez, é caracterizado por texto constitucional bastante lacônico no que se refere aos tratados internacionais”,189.

Em seu texto, há referências expressas sobre as competências para os procedimentos de celebração e incorporação de tratados internacionais.

Assim, nos termos do artigo 168, 20, “ao Presidente da República, atuando com o Ministro ou Ministros respectivos, ou com o Conselho de Ministros, compete concluir e subscrever tratados, necessitando para ratificá-los a aprovação do Poder Legislativo”, o que se completa com o disposto no artigo 85, $7^{\circ}$, que determina que “à Assembléia Geral compete decretar a guerra e aprovar ou reprovar por maioria absoluta dos votos do total de componentes de cada Câmara os tratados de paz, aliança, comércio e as convenções ou contratos de qualquer natureza que celebre o Poder Executivo com potências estrangeiras”. Trata-se de técnica presente nos demais ordenamentos jurídicoconstitucionais, como regra geral.

No mais, há regras esparsas no texto constitucional por meio das quais poderiam ser extraídas algumas poucas conclusões sobre a posição hierárquica desses tratados internacionais na ordem jurídica uruguaia.

Uma delas está no artigo 239, $1^{\circ}$, que prescreve que à Suprema Corte de Justiça compete "julgar a todos os infratores da Constituição, sem exceção alguma”, para, em seguida, incluir na competência dessa mesma Corte a análise das "questões relativas a tratados, pactos e convenções com outros Estados”. Há, aqui, a atribuição de competência à Suprema Corte uruguaia para julgar todos os atos normativos que

\footnotetext{
${ }^{188}$ Cf. Maria Elodia Almirón Prujel, Los derechos humanos, p.35.

${ }^{189}$ Constituição e tratados internacionais, p.40.
} 
contrariem a Constituição, o que a posiciona no vértice da ordem jurídica uruguaia, com todos os demais atos normativos a ela subordinados, inclusive os tratados internacionais. Pode-se extrair, pois, desse dispositivo que os tratados internacionais têm posição hierárquica infraconstitucional na ordem jurídica uruguaia.

Carmen González observa que, “em caso de conflito entre a norma internacional e a Constituição, a jurisprudência nacional tem-se pronunciado em favor da hierarquia superior da Constituição”, devendo essa infração ser submetida à apreciação da Suprema Corte de Justiça ${ }^{190}$.

Identificada a posição hierárquica infraconstitucional dos tratados internacionais na ordem jurídica uruguaia, resta determinar se a sua posição seria a mesma das leis internas ou se estariam eles em posição de destaque.

Respondem a essa indagação Heber Arbuet Vignali e Jean Michel Arrighi, para quem, "no tocante à oposição entre um tratado e uma lei posterior, e salvo algumas exceções, a Corte reiterou que apesar de não se ter consagrado a preleção dos tratados internacionais, estes também prevaleceriam sobre qualquer outra norma nacional contrária - ainda que fosse posterior - pois estes - que são a fonte mais importante do Direito Internacional - possuem uma eficácia superior à da lei interna dos Estados signatários; pelo que, no caso de conflito entre um e outro, prevalecerá o tratado”191.

Carmen González, por sua vez, apresenta panorama distinto, no que diz respeito ao entendimento dado pela jurisprudência à questão. Leciona González que, "nesse aspecto, ainda que a jurisprudência interna freqüentemente tenha equiparado a norma internacional à lei, entendemos que a norma internacional deve primar com relação à norma interna contrária, tendo em conta, entre outros argumentos, as disposições da Convenção de Viena de 1969 sobre Direito dos Tratados, que constituem direito positivo para o Uruguai, no sentido de que 'uma Parte não poderá invocar as disposições de seu direito interno como justificativa de descumprimento de um tratado. Esta norma entender-se-á sem prejuízo do disposto no artigo 46”,192.

Percebe-se, do acima exposto, que não há consenso sobre a posição hierárquica dos tratados internacionais na ordem jurídica uruguaia, o que se explica pelo tratamento lacônico dado ao assunto pelo texto constitucional. Esse panorama é muito semelhante ao brasileiro, antes da inserção do $\S 3^{\circ}$ ao artigo $5^{\circ}$ da Constituição.

\footnotetext{
${ }^{190}$ El relanziamiento, p.77.

191 Os vínculos entre o direito internacional público e os sistemas internos, p.418-419, apud Pedro Bohomoletz de Abreu Dallari, Constituição e tratados internacionais, p.40.

${ }^{192}$ El relanzamiento, p.78.
} 
Há, por fim, um último dispositivo constitucional que se refere a tratados internacionais. Prescreve o artigo 46, in fine, que “o Estado combaterá, por meio da lei e das Convenções Internacionais, os vícios sociais”. A menção feita pelo texto normativo às convenções internacionais, tomadas neste trabalho como equivalentes a tratados internacionais, ao lado da lei, conjugada com o disposto no artigo 239, $1^{\circ}$, torna possível a interpretação de que ambos, leis e tratados, são distintos e ambos são aplicados internamente; logo, tratados internacionais compõem a ordem jurídica interna uruguaia e são aplicados pelo juízos locais por força própria. 


\section{OS PRINCÍPIOS ADOTAdos PELA REPÚblica FEDERATIVA DO}

\section{BRASIL EM SUAS RELAÇÕES INTERNACIONAIS.}

Antes de descer à análise do procedimento de incorporação dos tratados internacionais de direitos humanos pelo ordenamento jurídico brasileiro e de sua posição hierárquica no plano das fontes normativas, faz-se mister o estabelecimento dos princípios sobre os quais se funda a República Federativa do Brasil, essencialmente no que diz respeito às suas relações no âmbito do direito internacional, vez que, “embora não seja pródiga nas estatuições pertinentes, a Constituição de 1988 revela os princípios que hão de nortear a espécie e o caminho a ser necessariamente percorrido para se incorporarem ao direito interno os tratados firmados pelo Brasil”193.

Uma observação preliminar deve ser feita seja com relação aos fundamentos ou aos objetivos da República Federativa do Brasil, seja com relação aos princípios a reger as suas relações internacionais: o texto constitucional formalizou, em razão de seu próprio processo de elaboração constituinte ${ }^{194}$, idéias, ao menos aparentemente, incompatíveis.

Esse conflito principiológico deve ser desfeito para que o sistema tenha operacionalidade. Para tanto, procurar-se-á uma conformação interpretativa, sem que se recorra, no entanto, à doutrina (pós-)moderna concernente a princípios e regras e à resolução de seus conflitos por meio da técnica de ponderação.

\subsection{Fundamentos da República Federativa do Brasil.}

Fundamento, para José Afonso da Silva, “é um termo tirado da Arquitetura, e significa aquilo sobre o qual repousa certa ordenação ou conjunto de conhecimento, aquilo que dá a alguma coisa sua existência ou sua razão de ser, aquilo que legitima a existência de alguma coisa”. Acrescenta o mesmo autor que os fundamentos da República Federativa do Brasil indicados no artigo $1^{\circ}$ da Constituição "são as bases sobre as quais ela assenta, enquanto Estado Democrático de Direito”; faltando um deles,

\footnotetext{
${ }^{193}$ Cf. Fernanda Dias Menezes de Almeida, A incorporação dos tratados, p.50.

${ }^{194}$ Cf. Manoel Gonçalves Ferreira Filho, Comentários, vol. 1, p.1-3; 10-11; nesta última página, afirma Ferreira Filho, referindo-se à interpretação do texto constitucional que "o triste, porém, é haver no seu texto princípios para todos os gostos, que, como diria um francês, 'hurlent de se trouver ensemble’”.
} 
“a República Federativa do Brasil não se caracterizará como Estado Democrático de Direito" 195 .

O primeiro dos fundamentos da República Federativa do Brasil é a soberania (artigo $1^{\circ}$, I, da Constituição).

Sobre a soberania estatal tratou-se anteriormente, quando se demonstrou a sua incompatibilidade com o modelo monista. Resta, aqui, reafirmar essa incompatibilidade, observando que, tendo sido adotada a soberania como fundamento da República Federativa do Brasil, não se pode sustentar a adoção do modelo monista de relações entre direito interno e direito internacional pelo Estado brasileiro, e sim o modelo dualista $^{196}$.

A cidadania é igualmente indicada como fundamento da República Federativa do Brasil, em seu artigo $1^{\circ}$, II. Manoel Gonçalves Ferreira Filho afirma que “enfatizando a cidadania, a nova Constituição brasileira quer apontar a indispensabilidade da participação popular na tomada das decisões políticas. O povo brasileiro deve ser composto de cidadãos, participantes ativos do exercício do poder democrático, não de súditos de qualquer poder, mesmo democrático”.

Para Oscar Vilhena Vieira, “a cidadania seria, assim, um conceito-chave para determinar nosso sentimento de pertencimento e participação numa determinada comunidade, tanto no aspecto político, jurídico-moral, como sócio-econômico. Pertencimento a participação política, como sujeitos ativos do processo de tomada de decisão coletiva. Pertencimento e participação jurídico-moral, enquanto sujeitos de direitos voltados à proteção da dignidade e realização da autonomia. Pertencimento e participação social e econômica, como produtores e beneficiários das riquezas (e demais recursos) socialmente produzidas”197.

Ambos os fundamentos - soberania e cidadania - têm assento ainda no parágrafo único do artigo $1^{\circ}$ da Constituição, segundo o qual “todo poder emana do povo, que o exerce por meio de representantes eleitos ou diretamente, nos termos desta Constituição”. É a consagração constitucional da democracia participativa, por meio da qual os cidadãos tomam as decisões políticas fundamentais e seus desdobramentos,

\footnotetext{
${ }^{195}$ Comentário, p.35.

${ }^{196}$ Nesse sentido, cf. Nadia de Araújo, A internalização dos tratados, p.5-6, para quem "quando da análise da validade dos tratados no ordenamento interno é preciso destacar dois momentos distintos: o da sua incorporação e, em seguida, o da sua posição hierárquica vis-à-vis às demais leis já existentes. E a partir da utilização desse critério, somente a corrente dualista tem lugar em nosso ordenamento jurídico, pois no sistema brasileiro o tratado só vige internamente depois de ter sido internalizado, segundo as normas anteriormente mencionadas".

${ }^{197}$ Direitos fundamentais, p.607.
} 
direta ou indiretamente, editando normas jurídicas às quais eles próprios sujeitar-seão ${ }^{198}$.

O terceiro fundamento do Estado Democrático de Direito indicado pelo texto constitucional é a dignidade da pessoa humana (artigo $1^{\circ}$, III). Trata-se de conceito fluido, equívoco, cujo conteúdo pode variar de acordo com a ordem jurídica ou ainda, ao longo do tempo, em uma mesma ordem jurídica. Para José Afonso da Silva, “a dignidade da pessoa humana não é uma criação constitucional, pois ela é um desses conceitos a priori, de um lado preexistente a toda experiência especulativa, tal como a própria pessoa humana. A Constituição, reconhecendo a sua existência e a sua eminência, transformou-a num valor supremo da ordem jurídica, quando a declara como um dos fundamentos da República Federativa do Brasil constituída em Estado Democrático de Direito”199.

Apesar da dificuldade de se conceituar a dignidade da pessoa humana, é ela apontada como o valor supremo, o princípio fundamental de qualquer Estado Democrático de Direito. Flávia Piovesan sustenta que “o valor da dignidade da pessoa humana impõe-se como núcleo básico e informador de todo ordenamento jurídico, como critério e parâmetro de valoração a orientar a interpretação e compreensão do sistema constitucional”200. Nesse mesmo sentido, segundo José Afonso da Silva, “a dignidade da pessoa humana constitui um valor que atrai a realização dos direitos fundamentais do homem, em todas as suas dimensões, e, como a democracia é o único regime político capaz de propiciar a efetividade desses direitos, o que significa dignificar o homem, é ela que se revela como o seu valor supremo, o valor que a dimensiona e humaniza”201.

Oscar Vilhena Vieira, por sua vez, após afirmar que a dignidade da pessoa não é um valor natural ou intrínseco ao ser humano, mas, sim, uma construção de natureza moral, parte da segunda formulação do imperativo categórico de Kant ("age de tal forma que trates a Humanidade, tanto em tua pessoa quanto na pessoa de qualquer outro, sempre como um fim e jamais simplesmente como um meio") e sustenta que "o princípio da dignidade, expresso no imperativo categórico, refere-se substantivamente à esfera de proteção da pessoa enquanto fim em si, e não como meio para a realização de

\footnotetext{
198 Cf., sobre democracia participativa, Elival da Silva Ramos, A ação popular, p.15-77, e, sobre as relações entre cidadania e democracia, Oscar Vilhena Vieira, Direitos fundamentais, p.606-628.

${ }^{199}$ A dignidade da pessoa humana, p.91.

${ }^{200}$ Direitos humanos e o direito constitucional internacional, p.55.

${ }^{201}$ A dignidade da pessoa humana, p.94.
} 
objetivos de terceiros. A dignidade afasta os seres humanos da condição de objetos à disposição de interesses alheios”202.

Os valores sociais do trabalho e da livre iniciativa são igualmente, por força do artigo $1^{\circ}, I V$, fundamento da República Federativa do Brasil. Parece ser essa uma das normas em que o legislador constituinte tentou conciliar o inconciliável. Contudo, uma leitura conciliadora desse princípio é apresentada por Eros Roberto Grau, para quem, "ao que tudo indica, as leituras que têm sido feitas do inciso IV do art. $1^{0}$ são desenvolvidas como se possível destacarmos de um lado 'os valores sociais do trabalho', de outro a 'livre iniciativa', simplesmente. Não é isso, no entanto, o que exprime o preceito. Este em verdade enuncia, como fundamentos da República Federativa do Brasil, o valor social do trabalho e o valor social da livre iniciativa” e, conclui o autor, "isso significa que a livre iniciativa não é tomada, enquanto fundamento da República Federativa do Brasil, como expressão individualista, mas sim no quanto expressa de socialmente valioso" ${ }^{\text {,203. }}$

Os valores sociais do trabalho e da livre iniciativa, colocados lado a lado no texto constitucional, assentados como fundamento da República Federativa do Brasil, expressam a opção constituinte pela democracia social, por meio da qual uma conciliação entre liberdade e igualdade. É o que afirma Elival da Silva Ramos, para quem, no Estado social, “procedeu-se à reinterpretação dos elementos que compõem os alicerces da democracia, de modo a buscar um ajuste mais adequado entre liberdade e igualdade, sob o signo da dialética de complementariedade”204. Assim, igualdade e liberdade, valores sociais do trabalho e da livre iniciativa não se excluem, mas, sim, complementam-se. Trata-se do fundamento, por exemplo, da função social da propriedade, garantida pelo artigo 5º XXIII, da Constituição de 1988.

O último fundamento apontado pelo texto constitucional é o pluralismo político (artigo $1^{\circ}$, V). Trata-se, segundo Manoel Gonçalves Ferreira Filho, do reconhecimento do "valor intrínseco do pluralismo de idéias e opiniões no plano político. Conseqüência disso é a recusa de toda tese que vise, por exemplo, a implantar um partido único ou a estabelecer uma doutrina oficial. Neste ponto a Constituição põe em destaque um princípio que é considerado fundamental nas democracias de derivação liberal”205.

\footnotetext{
${ }^{202}$ Direitos fundamentais, p.64-68.

${ }^{203}$ A ordem econômica, p.242.

${ }^{204}$ Perspectivas de evolução, p.327.

${ }^{205}$ Comentários, p.19.
} 
Há, assim, uma clara opção por uma sociedade pluralista, cujo instrumento de tomada de decisões é a adoção da regra da maioria - até porque o sistema deve ter operacionalidade - mas sem desconsiderar as minorias. Monica Herman Salem Caggiano, em monografia sobre a oposição na política, apresenta a contraposição do governo da maioria e do governo da minoria como a pedra de toque do modelo democrático, afirmando que "as minorias não podem ser ignoradas”; conclui a autora que "configura, destarte, ponto nevrálgico da questão a razoável e equilibrada distribuição do poder visando a que seja esse atribuído ao mesmo tempo às maiorias e às minorias, essas últimas inexpulsáveis do cenário decisório, em especial por detentoras do direito de oposição"206.

A garantia do pluralismo político como fundamento da República Federativa do Brasil é pressuposto necessário para a participação política, elemento propulsor por excelência do processo de construção da realidade democrática. Elival da Silva Ramos, partindo da concepção de democracia como "um sistema político empenhado na contínua busca de seu próprio aperfeiçoamento", afirma que, “nesse processo de construção da realidade democrática e de aperfeiçoamento do ideal que a anima, o elemento propulsor por excelência, como convém sublinhar, é a participação política, uma vez que, por meio dela e de seus canais, as necessidades concretas do povo vêm à tona, e são tomadas as medidas tendentes a satisfazê-las”, para concluir que “é a participação, não raro, que alarga o seu próprio leito, qual rio caudaloso, convertendo-se em princípio de sua própria intensificação”207.

Oscar Vilhena Vieira, nesse sentido, associa o pluralismo político ao respeito pelos direitos humanos. Para Vilhena, “o discurso dos direitos humanos deve ser prático, responsável e acessível a uma pluralidade de perspectivas. Ele deve engajar os grupos desprezados e invisíveis como proponentes das mudanças que considerem necessárias à justiça. Obviamente, a sociedade civil é a origem dos conflitos entre os clamores por justiça, e um aspecto do diálogo é a negociação entre vários direitos e a distribuição dos recursos para serem investidos em soluções”208.

Em síntese, são esses os fundamentos da República Federativa do Brasil. Toda a atuação estatal e mesmo as relações entre os particulares devem tomá-los como

\footnotetext{
${ }^{206}$ Oposição na política, p.40.

${ }^{207}$ A ação popular, p.28-29.

208 Direitos humanos, p.144, seguido de uma análise mais específica sobre a fragmentação e a neutralização do discurso de efetivação dos direitos humanos.
} 
princípio e limite de atuação ${ }^{209}$. Mesmo os objetivos fundamentais e os princípios regentes da República Federativa do Brasil em suas relações internacionais, analisados a seguir, não podem desconsiderá-los.

\subsection{Objetivos fundamentais da República Federativa do Brasil.}

Objetivo, segundo José Afonso da Silva, "é um signo que aponta para a frente, indicando um ponto adiante a ser alcançado pela prática de alguma ação - aqui: ação governamental. 'Fundamental' , aqui, é adjetivo que se refere ao que se tem como mais relevante no momento, ao que é prioritário e básico” ${ }^{\text {,10. }}$

Objetivos fundamentais da República Federativa do Brasil nada mais são do que a finalidade do Estado brasileiro, concebida por Dalmo de Abreu Dallari, ao lado da soberania, território e povo, como um dos elementos constitutivos de qualquer Estado. Para Dallari, “o problema da finalidade do Estado é de grande importância prática, sendo impossível chegar-se a uma idéia completa de Estado sem ter consciência de seus fins" e segue o mesmo autor observando que "a falta de consciência das finalidades é que faz com que, não raro, algumas funções importantes, mas que representam apenas uma parte do que o Estado deve objetivar, sejam tomadas como finalidade única ou primordial, em prejuízo de tudo o mais”211.

Percebe-se, pois, que os objetivos arrolados pelo texto constitucional não são os únicos do Estado brasileiro, mas, sim, os fundamentais. Outras finalidades, desde que não contrárias ao sistema constitucional, podem ser perseguidas pela ação governamental, mas esta não deve perder de vista os objetivos expressamente indicados pela Constituição.

São objetivos da República Federativa do Brasil, arrolados pelo artigo $3^{\circ}$ da Constituição de 1988, “construir uma sociedade livre, justa e solidária”, "garantir o desenvolvimento nacional”, “erradicar a pobreza e a marginalização e reduzir as desigualdades sociais e regionais" e, por fim, "promover o bem de todos, sem preconceitos de origem, raça, sexo, cor, idade e quaisquer outras formas de discriminação”.

\footnotetext{
${ }^{209}$ Para a discussão sobre os direitos fundamentais nas relações entre particulares, cf. Virgílio Afonso da Silva, A constitucionalização do direito.

${ }^{210}$ Comentário contextual, p.46.

${ }^{211}$ Elementos de teoria, p.102.
} 
3.3. Princípios regentes da República Federativa do Brasil em suas relações internacionais.

Reger-se, ainda segundo José Afonso da Silva, “é um signo de subordinação que vale dizer que seu sujeito - 'República Federativa do Brasil' - se submete aos elementos componentes do agente - 'pelos seguintes princípios' - nas circunstâncias indicadas - 'nas relações internacionais'. Por aí se vê que esses princípios são plenamente eficazes e de observância obrigatória, ainda que alguns se apresentem com enunciados constitucionalmente abertos - como 'independência nacional'; mas todos são conceitos plenamente determináveis pela doutrina"212.

Pedro Bohomoletz de Abreu Dallari observa que "não se pode ignorar a relevância das normas constitucionais que explicitamente tratam das relações exteriores de um país. De um lado, porque, ao fixarem competências para os distintos organismos, poderes e esferas do Estado, podem contribuir, considerando-se a evolução de sistemas cada vez mais complexos de gestão pública, para uma reversão da percepção desfocada dos paradigmas das relações exteriores de um país, que os retrata enquanto decorrência automática da política externa governamental, pois instituições não necessariamente vinculadas a esta última, como o parlamento, passam a ter maiores atribuições em torno de questões internacionais. De outro lado, porque, ao fixarem princípios, as normas constitucionais estabelecem a primazia dos valores que não deixam de permear não só a retórica, mas a própria materialização dos atos decorrentes da política externa”213. Nesse mesmo sentido, acrescenta Pedro Dallari que esses princípios “repercutem em diversos dispositivos constitucionais não só localizadores da presença brasileira na comunidade internacional, mas, inclusive, disciplinadores de direitos inerentes à ordem jurídica interna”,214.

Deve a República Federativa do Brasil, assim, submeter-se aos princípios indicados pelo artigo $4^{\circ}$ da Constituição de 1988 no desenvolvimento de suas relações internacionais. Pesam esses princípios mais diretamente sobre o Presidente da República, a quem o texto constitucional, em seu artigo 84, VII, determinou "manter relações com Estados estrangeiros e acreditar seus representantes diplomáticos” e não

\footnotetext{
${ }^{212}$ Comentário contextual, p.50.

${ }^{213}$ Constituição e relações exteriores, p.18.

${ }^{214}$ Constituição e relações exteriores, p.154.
} 
pode ele, no exercício dessa atribuição, optar por se submeter ou não a esses mandamentos constitucionais.

São princípios arrolados pelo artigo $4^{\circ}$ da Constituição a independência nacional (inciso I), a prevalência dos direitos humanos (inciso II), a autodeterminação dos povos (inciso III), a não-intervenção (inciso IV), a igualdade entre os Estados (inciso V), a defesa da paz (inciso VI), a solução pacífica dos conflitos (inciso VII), o repúdio ao terrorismo e ao racismo (inciso VIII), a cooperação entre os povos para o progresso da humanidade (inciso IX), a concessão de asilo político (inciso X), bem como a busca da integração econômica, política, social e cultural dos povos da América Latina, visando à formação de uma comunidade latino-americana de nações (parágrafo único).

Problemas interpretativos, contudo, podem surgir desse dispositivo constitucional. Nesse sentido, afirma Manoel Gonçalves Ferreira Filho ser “visivelmente ambíguo este dispositivo constitucional que reflete inspirações nitidamente divergentes”, apontando, em seguida, três dessas inspirações: uma nacionalista (incisos I, IV e V), outra internacionalista (incisos II, III e VIII) e uma última de “ideais sem dúvida de aplauso universal”, como a defesa da paz (incisos VI, VII, IX e X) ${ }^{215}$. Por sua vez, indica José Afonso da Silva quatro inspirações para o dispositivo: uma nacionalista (incisos I, III, IV e V), outra internacionalista (incisos II e VIII), outra pacifista (incisos VI, VII e X) e uma última orientação comunitária (inciso IX e parágrafo único) ${ }^{216}$.

A seguir, proceder-se-á à análise dos princípios regentes da República Federativa do Brasil em suas relações internacionais, de acordo com a classificação proposta por José Afonso da Silva.

3.3.1. Princípios nacionalistas: a independência nacional, a autodeterminação dos povos, a não-intervenção e a igualdade entre os Estados.

Os princípios nacionalistas, regentes da República Federativa do Brasil em suas relações internacionais, têm como fundamento comum a soberania estatal. Independência nacional, autodeterminação dos povos, não-intervenção e igualdade entre os Estados pressupõem soberania estatal. São, na verdade, manifestações distintas,

${ }^{215}$ Comentários, p.21.

${ }^{216}$ Comentário contextual, p.50. 
dimensões diversas da soberania estatal e das relações entre os Estados soberanos no seio da comunidade internacional.

Independência nacional é a não-submissão de um Estado, na tomada de suas decisões políticas fundamentais, a qualquer outro Estado ou ente internacional, incorporando normas internacionais, como os tratados, no exercício de sua soberania, para que elas sejam aplicadas internamente. Trata-se, assim, de expressão da face externa da soberania estatal.

Pedro Bohomoletz de Abreu Dallari observa que "a menção ao princípio da independência nacional suscita automaticamente sua correspondência com a noção de soberania e com a forma pela qual ela se espraia pelo texto constitucional”, chamando a atenção para a influência do dispositivo nas áreas econômica e cultural ${ }^{217}$.

Nesse sentido, Miguel Reale aduz que "independência externa e supremacia valem, juridicamente, como poder de legislar, não no sentido de criar substancialmente o Direito, mas no de decidir em última instância sobre a positividade do Direito"218. Também José Afonso da Silva sustenta que “esse princípio reafirma o da soberania, que é fundamento da República Federativa do Brasil. Essa reafirmação, neste passo, não é destituída de importância, por não ser pura redundância. A independência constitui a face externa da soberania e, como vimos, significa que na ordem internacional, não tem de acatar regras que não sejam voluntariamente aceitas e está em pé de igualdade com os poderes supremos dos outros povos" ${ }^{219}$.

O princípio da autodeterminação dos povos, por sua vez, está ligado à dimensão externa e também à dimensão interna da soberania estatal. Cada pessoa, em regra, é ligada juridicamente a um Estado, o que lhe atribui uma determinada nacionalidade $\mathrm{2}^{20}$. As pessoas ligadas entre si pela mesma nacionalidade são consideradas como o povo de um determinado Estado e cabe a todos os povos "o direito de estabelecer livremente sua condição política e de determinar seu desenvolvimento econômico, social e cultural”221.

Estão, assim, os princípios da independência nacional e da autodeterminação dos povos intimamente relacionados. Em razão do princípio da autodeterminação dos

\footnotetext{
${ }^{217}$ Constituição e relações exteriores, p.158-160.

${ }^{218}$ Teoria do Direito, p.205.

${ }^{219}$ Comentário contextual, p.50.

220 Sobre a nacionalidade, cf. Celso D. de Albuquerque Mello, Direito constitucional internacional, p.207-219, e do mesmo autor, Curso, p.929-946.

${ }^{221}$ Cf. José Afonso da Silva, Comentário contextual, p.50-51, e Manoel Gonçalves Ferreira Filho, Direitos humanos fundamentais, p.61-62.
} 
povos, em sua acepção externa, que se pode afirmar o direito de os povos constituíremse em Estado soberano e são as decisões estatais tomadas pelo povo de determinado Estado, com fundamento no princípio da autodeterminação dos povos, no exercício de sua soberania em seu sentido interno, que não se submetem aos demais Estados ou outros entes internacionais, como expressão do princípio da independência nacional, igualmente no exercício da soberania em sua acepção externa. Independência nacional e autodeterminação dos povos são, pois, dimensões diversas de uma mesma soberania.

Os princípios da não-intervenção e da igualdade entre os Estados são também expressões da soberania estatal. Os Estados, no cenário internacional, estão em uma relação de coordenação entre si, e não de subordinação. Sobre o princípio da igualdade entre os Estados, aduz Pedro Dallari que, “derivado da lógica emanada da Paz de Westfália, que, como já foi visto anteriormente, configurou a ordem internacional com base na interação, em condições formais de igualdade, de Estados soberanos, o princípio constitucional em exame permanece como paradigma do sistema de relações em nível global”, observando que, assim como a mudança de concepção do princípio da igualdade na seara do direito constitucional, deve ser esse princípio igualmente concebido, no seio do direito internacional, em sua acepção material, e não simplesmente em seu sentido formal ${ }^{222}$.

Dessa forma, estão eles em uma relação de igualdade, não existindo prevalência de um em relação a outro, o que não permite, por conseqüência, a ingerência de um Estado nas decisões políticas fundamentais de outro. Ademais, inúteis seriam os princípios da independência nacional e da autodeterminação dos povos se fosse permitida, no cenário internacional, a intervenção, armada ou não, de um Estado em outro $^{223}$. A própria soberania estatal estaria com isso ameaçada.

Os princípios nacionalistas assentados no artigo $4^{\circ}$ da Constituição de 1988 são, em síntese, expressões diversas da soberania estatal, tendo função de garantia desse fundamento da República Federativa do Brasil em suas relações internacionais.

3.3.2. Princípios internacionalistas: a prevalência dos direitos humanos e o repúdio ao terrorismo e ao racismo.

${ }^{222}$ Constituição e relações exteriores, p.168-170. Refere-se o autor à Carta de Direitos e Deveres Econômicos dos Estados, proclamada pela Assembléia Geral da ONU, em 1972, que, em seu artigo $1^{\circ}$, prescreve que "todo Estado tem o direito soberano e inalienável de eleger seu sistema econômico, assim como seus sistemas político, social e cultural, de acordo com a vontade de seu povo, sem ingerência, coação e nem ameaças externas de nenhuma classe”.

${ }^{223}$ Cf. José Afonso da Silva, Comentário contextual, p.51. 
A prevalência dos direitos humanos, nas palavras de Flávia Piovesan, “como princípio a reger o Brasil no âmbito internacional, não implica apenas no engajamento do país no processo de elaboração de normas vinculadas ao Direito Internacional dos Direitos Humanos, mas implica na busca da plena integração de tais regras à ordem jurídica interna brasileira” e, segue a autora, “implica, ademais, no compromisso em adotar uma posição política contrária aos Estados em que os direitos humanos sejam gravemente desrespeitados"224.

Sobre a prevalência dos direitos humanos, já se tratou anteriormente, ao serem discutidos os conflitos entre normas do direito interno e normas do direito internacional e os critérios para a sua resolução.

Em suma, foi apresentado o princípio como um dos critérios de solução de conflito entre norma de direito interno e norma de direito internacional, mas não como o único deles, o que acarretaria, em última análise, na total desconsideração da soberania estatal, e não somente em sua “flexibilização” ou “relativização”, como propõe Flávia Piovesan $^{225}$.

A aplicação desse princípio, como proposto anteriormente, parece ser mais conciliatória com o fundamento da soberania estatal. Ademais, a aplicação proposta não deixa de contemplar as três contribuições da primazia das normas mais favoráveis às pessoas protegidas apresentadas por Antônio Augusto Cançado Trindade: (1) "reduzir ou minimizar consideravelmente as pretensas possibilidades de 'conflitos' entre instrumentos legais em seus aspectos normativos”, (2) “obter maior coordenação entre tais instrumentos, em dimensão tanto vertical (tratados e instrumentos de direito interno) quanto horizontal (dois ou mais tratados)" e (3) “demonstrar que a tendência e o propósito da coexistência de distintos instrumentos jurídicos - garantindo os mesmos direitos - são no sentido de ampliar e fortalecer a proteção”226.

O segundo princípio internacionalista é o repúdio ao terrorismo e ao racismo.

Terrorismo "é o meio pelo qual o agente - o terrorista - produz uma ação extraordinariamente violenta (o terror) com o objetivo de criar uma situação de medo profundo, visando a atingir um fim determinado ou à dominação política”227. O traço marcante do terrorismo é a sua atuação inesperada, pois o seu agente, em regra, está

\footnotetext{
${ }^{224}$ Direitos humanos, p.63.

${ }^{225}$ Direitos humanos, p.64.

${ }^{226}$ Tratado, vol. I, p.436.

${ }^{227}$ Cf. José Afonso da Silva, Comentário contextual, p.52.
} 
inserido no seio social como qualquer outro indivíduo, podendo sua ação atingir tanto agentes públicos, políticos ou não, quanto civis. É exatamente esse fator surpresa que causa a sensação de insegurança social e de descrédito do Estado, que deveria assegurar a não-violação da segurança pública.

Racismo, por sua vez, "é teoria e comportamento destinados a realizar e justificar a supremacia de uma raça sobre outra”228. Há o entendimento de que uma raça é superior a outra, podendo dominá-la ou mesmo eliminá-la. Exemplo sempre lembrado e que deu causa, em amplitude mundial, a uma releitura do sistema de proteção dos direitos humanos, foi a perseguição operada contra os judeus pelos pertencentes à raça ariana, considerada por estes como pura e superior. Fazer triunfar a lei da comunidade do sangue, sagrada e natural, contra todas as leis falsas e artificiais era a missão de Adolf Hitler ${ }^{229}$.

Deve posicionar-se, pois, o Estado brasileiro em sentido contrário à prática do racismo e da tortura. Mais que isso. É dever do Estado brasileiro repulsar atividades terroristas ou racistas, o que implica em ação estatal: a República Federativa do Brasil deve atuar, interna ou internacionalmente, de maneira a combater atividades terroristas ou racistas, mas sem violar direitos fundamentais outros, igualmente garantidos pelo sistema constitucional.

3.3.3. Princípios pacifistas: defesa da paz, solução pacífica dos conflitos e concessão de asilo político.

Defesa da paz, segundo Celso de Albuquerque Mello, pode ter duas acepções ${ }^{230}$. Pela primeira delas, defesa da paz seria entendida, em um sentido vulgar, como a busca, pelo Estado, da exclusão de qualquer combate armado. Por outro lado, defesa da paz poderia ser entendida como direito à paz ${ }^{231}$, enquadrando-se entre os denominados direitos de solidariedade ou de terceira dimensão. Por fim, reconhece Celso de

\footnotetext{
${ }^{228}$ Cf. José Afonso da Silva, Comentário contextual, p.52.

${ }^{229}$ Cf. Jean-Jacques Chevallier, As grandes obras políticas, p.392.

${ }^{230}$ Direito constitucional internacional, p.147.

${ }^{231}$ Manoel Gonçalves Ferreira Filho, Direitos humanos fundamentais, p.59, ao que parece, não concebe essa previsão constitucional como a consagração, pelo texto constitucional de 1988, do direito à paz. Afirma Ferreira Filho que inexiste no plano constitucional consagração expressa e direta desse direito fundamental de terceira dimensão e que a Constituição brasileira de 1988 “chegou perto” ao prever a defesa da paz entre os princípios regentes da República Federativa do Brasil nas suas relações internacionais.
} 
Albuquerque Mello “que a paz é mais um ideal do que a realidade, mas ela é a própria razão de ser do DIP nos dias que correm"232.

A defesa da paz, concebida como um direito fundamental, enfrenta, contudo, alguns obstáculos para a sua efetivação, decorrentes principalmente da indeterminação de sua titularidade. A inexistência de um titular determinado torna, de fato, mais difícil a defesa desse direito. Não há dúvidas, por outro lado, que o primado da paz passa, “com a nova Constituição, da condição de paradigma inspirador do tratamento constitucional dos marcos dirigentes da figuração internacional do Brasil para a condição de princípio constitucional explícito, que se associa a outros por ele inspirados, como a defesa da solução pacífica dos conflitos"233.

Outro obstáculo para a defesa da paz é apresentado por Oscar Vilhena Vieira ${ }^{234}$, ao comentar episódio histórico acerca de uma carta encaminhada, em 1932, por Albert Einstein a Sigmund Freud. Relata o autor que, nessa carta, "Einstein perguntava se seria possível um dia vivermos em paz”. Segue Vilhena, narrando que "Freud responde à carta afirmando que dificilmente viveremos um dia em paz, por uma razão muito simples: os seres humanos são formados, a princípio, por dois instintos básicos; o instinto de vida e o instinto de morte. O primeiro é responsável pelo amor que podemos sentir por outras pessoas, pela cultura que somos capazes de construir, pela solidariedade que somos capazes de ter. O segundo, pela agressividade, pelo sentido de competição e pela violência. A grande questão, dizia Freud, é que não somos capazes de viver sem os instintos de morte, sem agressividade não sobreviveríamos, sequer sairíamos de casa para trabalhar”. O ceticismo de Freud, segundo o autor, traz, contudo, “alguma expectativa”, pois “os únicos instrumentos capazes de, senão eliminar, pelo menos domesticar a nossa violência, seriam o Direito e a cultura”.

O princípio da solução pacífica dos conflitos, adotado tradicionalmente pela ordem constitucional brasileira ${ }^{235}$, decorre lógica e diretamente do princípio de defesa da paz. O Estado brasileiro, ao acolher entre os seus princípios a busca da exclusão de qualquer combate armado, deve necessariamente buscar solucionar seus conflitos internacionais de maneira pacífica, isto é, sem recorrer à guerra.

Celso de Albuquerque Mello apresenta três modos de soluções pacíficas de litígios internacionais: diplomáticos (negociações diplomáticas, serviços amistosos,

\footnotetext{
${ }^{232}$ Direito constitucional internacional, p.148.

${ }^{233}$ Cf. Pedro Bohomoletz de Abreu Dallari, Constituição e relações exteriores, p.171.

${ }^{234}$ Direitos humanos, p.22-23.

235 Cf. José Afonso da Silva, Comentário contextual, p.51.
} 
mediação e bons ofícios), políticos (soluções dadas pelas organizações internacionais) e jurídicos (comissões de inquérito, conciliação, arbitragem e soluções judiciárias) ${ }^{236}$. Há, assim, uma série de possibilidades de solução de litígios internacionais que não a guerra.

Pedro Bohomoletz de Abreu Dallari, sobre o último dos princípios, leciona que “a Constituição de 1988 é a primeira na história brasileira a incluir expressamente o direito de asilo político entre os princípios que servem de parâmetro para as relações exteriores do País. Porém, o instituto não é desconhecido do sistema constitucional e legal brasileiro; ao contrário, constitui regra tradicional - quer quando literalmente afirmado, quer como decorrência da vedação da extradição de estrangeiro por delito de natureza política -, reproduzida nos textos constitucionais com pequenas variações quanto à redação, embora sempre focada exclusivamente no âmbito das normas asseguradoras dos direitos e garantias individuais”237.

Asilo político, segundo Alexandre de Moraes, “consiste no acolhimento de estrangeiro por parte de um Estado que não o seu, em virtude de perseguição por ele sofrida e praticada ou por seu próprio país ou, ainda, por terceiro. As causas motivadoras dessa perseguição, ensejadora da concessão do asilo, em regra, são: dissidência política, livre manifestação de pensamento ou, ainda, crimes relacionados com a segurança do Estado, que não configurem delitos no direito penal comum,238. Deve-se atentar, contudo, para a possibilidade de, em determinado Estado, estarem algumas condutas típicas de crimes políticos positivadas como direito penal comum, ao lado de outros crimes considerados comuns.

Pedro Dallari, após delinear a concessão de asilo político como uma forma de proteção de pessoas que se encontrem ameaçadas em sua vida ou liberdade por perseguições em outros Estados, seja por suas autoridades, seja por pessoa ou grupo de pessoas não ligadas institucionalmente a esse Estado, observa que a inserção desse dispositivo no rol dos princípios constitucionais de relações exteriores "certamente tem respaldo na experiência recente dos governos autoritários do Brasil e da América Latina, que demonstrou ser o instituto do asilo político mecanismo fundamental de solidariedade internacional operado pelos regimes democráticos”239.

\footnotetext{
${ }^{236}$ Curso, p.1357-1403.

${ }^{237}$ Constituição e relações exteriores, p.180.

${ }^{238}$ Direitos humanos fundamentais, p.80.

${ }^{239}$ Constituição e relações exteriores, p.181-182.
} 
3.3.4. Princípios de orientação comunitária: a cooperação entre os povos para o progresso da humanidade e a busca da integração econômica, política, social e cultural dos povos da América Latina, visando à formação de uma comunidade latino-americana de nações.

O primeiro dos princípios de orientação comunitária é de caráter mais geral, ligado aos objetivos últimos de toda a comunidade internacional ou pelo menos grande parte dela. Trata-se de princípio que tem sua raiz na solidariedade ou fraternidade internacional, idéia comum dos direitos fundamentais de terceira geração.

Por esse princípio, obriga-se o Estado brasileiro a coordenar seu empenho com outros Estados para o desenvolvimento econômico e social da comunidade internacional como um todo. A submissão da República Federativa do Brasil a esse princípio em suas relações internacionais não implica na desconsideração de sua soberania, uma vez que a atuação em cooperação pressupõe situação de igualdade entre as partes, e não de subordinação $^{240}$.

O segundo dos princípios de orientação comunitária, contudo, é mais específico, pois regional, ainda que bastante genérico no que tange às possibilidades de sua efetivação.

Nesse sentido, Pedro Dallari observa que "mais do que um princípio genérico normatizador da postura internacional do Brasil, os comentaristas têm identificado no dispositivo em tela a condição de simples regra voltada para a explicitação de um objetivo programático almejado pelo País. O próprio debate havido no interior da Constituinte envolvendo a eventual conveniência da alocação do texto deste parágrafo no rol das disposições transitórias da Constituição é evidenciador dessa compreensão”, afirmando o autor, em seguida, que "tem sido ressaltada, igualmente, a ausência de mecanismos constitucionais capazes de dar sentido concreto a tal regra

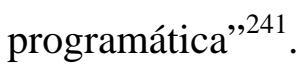

Uma dessas possibilidades de efetivação é, sem dúvidas, o Mercosul. Para Pedro Dallari, "além da influência evidente do dispositivo em questão para a política externa brasileira, não se devem desconhecer as possibilidades de repercussão que se envolve no âmbito do sistema jurídico do País”, uma vez que "tal fundamentação viabiliza a incorporação ao sistema jurídico, com amparo na Constituição, de regras que assegurem

\footnotetext{
${ }^{240}$ Cf. José Afonso da Silva, Comentário contextual, p.52.

${ }^{241}$ Constituição e relações exteriores, p.183.
} 
tratamento diferenciado às pessoas, físicas e jurídicas, e aos produtos originários dos Estados latino-americanos"; e conclui o autor que "o aceso debate em torno do MERCOSUL e das regras destinadas a disciplinar sua efetiva implementação decorre exatamente da constatação dos efeitos extremamente relevantes que recairão sobre os diferentes ramos do Direito interno"242.

Anda sobre o Mercosul, leciona Enrique Ricardo Lewandowski que a organização internacional "objetiva a criação de um mercado comum, portanto uma integração qualitativamente superior a uma simples união aduaneira ou uma zona de livre comércio, eis que, como tal, pretende alcançar o livre fluxo de pessoas, bens capitais e serviços, de maneira a atingir, conforme estabelece o Tratado de Assunção, o desenvolvimento econômico dos países que o integram, dentro dos marcos da justiça social, mediante a coordenação das respectivas 'políticas macroeconômicas e setoriais' e a 'adoção de uma política comum com relação a terceiros Estados' (art. $1^{\text {o }}$ ), dentre outras medidas" 243 .

3.4. Compatibilidade entre os fundamentos, os objetivos e os princípios regentes da República Federativa do Brasil em suas relações internacionais.

Há duas justificativas para a análise dos fundamentos, dos objetivos e dos princípios regentes da República Federativa do Brasil em suas relações internacionais da maneira como se procedeu anteriormente no âmbito do presente trabalho.

A primeira delas é apresentar os pressupostos da análise que se fará sobre as relações entre o direito internacional e o direito interno brasileiro, mais especificamente a incorporação dos tratados internacionais de direitos humanos pela República Federativa do Brasil e a sua posição hierárquica no plano das fontes normativas. É partindo-se desses pressupostos apresentados que se chegará às conclusões deste trabalho; pressupostos distintos poderiam levar a conclusões igualmente distintas.

A segunda justificativa é fundamentar a afirmação de que não há incompatibilidade entre os fundamentos, os objetivos e os princípios regentes da República Federativa do Brasil em suas relações internacionais.

Na verdade, toda atuação, interna ou internacional, do Estado brasileiro deve ser compatível com seus fundamentos e deve direcionar-se aos objetivos positivados no

\footnotetext{
${ }^{242}$ Constituição e relações exteriores, p.184-185.
}

${ }^{243}$ A proteção dos direitos humanos, p.269. 
texto constitucional. Não há hierarquia entre as normas constitucionais, mas é lógico afirmar que a atuação da República Federativa do Brasil em suas relações internacionais é instrumento de concretização dos objetivos da República, que, por sua vez, devem estar de acordo com seus fundamentos.

Não há, nessa esteira, incompatibilidade entre soberania e dignidade da pessoa humana, ambos fundamentos da República Federativa do Brasil. O Estado brasileiro, no exercício de sua soberania, deve buscar o Bem Comum, o que não contraria, em absoluto, a dignidade da pessoa humana.

O mesmo deve ser dito quando se confronta a soberania estatal, fundamento do Estado brasileiro, e a prevalência dos direitos humanos, princípio regente da República Federativa do Brasil em suas relações internacionais. É exatamente no exercício de sua soberania que o Estado brasileiro, por exemplo, firma tratados internacionais para a proteção de direitos humanos.

O que se quer aqui sustentar é que o exercício da soberania estatal não leva necessariamente ao descumprimento dos direitos humanos ou ao desrespeito à dignidade da pessoa humana. Do mesmo modo, não se pode conceber a atuação da República Federativa do Brasil em suas relações internacionais à revelia de sua soberania.

É por meio dos processos de celebração e de incorporação dos tratados internacionais de direitos humanos que o Estado brasileiro exerce sua soberania, em prol da dignidade da pessoa humana. São esses os procedimentos estudados nos itens a seguir. 


\section{PROCEDimentos DE CELEBRAÇÃo E DE INCORPORAÇÃo DOS} TRATADOS INTERNACIONAIS DE DIREITOS HUMANOS AO DIREITO INTERNO BRASILEIRO.

Vistos os pressupostos básicos da incorporação dos tratados internacionais de direitos humanos pela ordem jurídica interna e traçado o perfil constitucional da República Federativa do Brasil, por meio de seus fundamentos, objetivos e princípios regentes de suas relações internacionais, deve-se passar à apresentação dos dispositivos específicos do texto constitucional que dizem respeito aos procedimentos de celebração e de incorporação desses tratados, dando-se especial atenção ao artigo 50 $5^{\circ} 3^{\circ}$, da Constituição da República Federativa do Brasil, acrescentado pela emenda constitucional $n^{\circ} 45 / 04^{244}$.

4.1. Distinção entre procedimento de celebração e procedimento de incorporação.

Deve-se distinguir, inicialmente, procedimento de celebração e procedimento de incorporação dos tratados internacionais. A distinção é bastante simples.

O procedimento de celebração de um tratado internacional de direitos humanos estende-se do início de suas tratativas, que pode se dar de diversas maneiras, como a troca de notas diplomáticas, até a sua ratificação. Na hipótese de o Estado brasileiro não participar das negociações do tratado, não o tendo assinado no momento apropriado, o procedimento de celebração restringir-se-á à adesão a ele; trata-se a adesão, pois, de um procedimento de celebração abreviado.

Ratificado o tratado internacional de direitos humanos pelo Estado brasileiro, resta proceder-se à sua incorporação. É a ratificação que vincula o Estado brasileiro ao tratado internacional e é a partir desse momento que faz sentido incorporá-lo, e não antes, pois somente faz sentido incorporar algo já existente.

Apresentados dessa maneira, fica clara, em linhas gerais, a distinção entre ambos os procedimentos. Contudo, no direito brasileiro, a participação do Congresso Nacional no procedimento de celebração dos tratados internacionais de direitos humanos, por

\footnotetext{
${ }^{244}$ Para uma análise detida do histórico da aprovação da Emenda Constitucional no $45 / 05$, no que tange ao artigo $5^{\circ}, \S 3^{\circ}$, cf. Maria Paula Alves de Souza, Integração dos tratados.
} 
força do artigo 49, I, da Constituição, faz com que, por vezes, sejam confundidos os procedimentos, especialmente do momento que vai da assinatura do tratado à sua ratificação. Tal confusão deve ser desfeita.

4.2. Procedimento de celebração dos tratados internacionais de direitos humanos pela República Federativa do Brasil.

4.2.1. Negociação e assinatura do tratado pelo Poder Executivo.

As negociações são a primeira fase do procedimento de celebração de qualquer tratado internacional e são elas encerradas com a assinatura do texto do tratado pelas partes. As negociações podem ser bilaterais, coletivas comuns ou coletivas no interior de organizações internacionais ${ }^{245}$.

Não há regras predeterminadas para a iniciativa das negociações com vistas à celebração de um tratado internacional bilateral. Segundo Rezek, a iniciativa se dá "pelo acaso, pela variedade circunstancial, pelo juízo político de conveniência”, ainda que seja comum o convite à negociação bilateral feito por meio de nota diplomática de uma parte à outra ${ }^{246}$. O lugar das negociações, em regra, é o território de uma das partes e o idioma a ser lavrado o tratado varia de acordo com as circunstâncias (idioma ou idiomas das partes contratantes); o procedimento adotado com mais freqüência é informal, não envolvendo delegações, com prazos estritos para término das tratativas ${ }^{247}$.

Nas negociações coletivas comuns, entendidas por Rezek como "toda negociação coletiva que não se desenvolva no interior de uma organização internacional, e que tenha dessarte por cenário uma conferência internacional ad hoc ainda que sob os auspícios, o incentivo ou a simpatia de uma ou de várias organizações”248, a iniciativa se dá por meio de convites direcionados a destinatários diversos e as negociações costumam se desenvolver no território do Estado responsável pela iniciativa ${ }^{249}$. O idioma a ser lavrado o tratado, assim como nos bilaterais, depende do idioma ou dos idiomas das partes contratantes, já o procedimento é mais complexo e

\footnotetext{
${ }^{245}$ Cf. José Francisco Rezek, Direito dos tratados, p.185-239.

${ }^{246}$ Direito dos tratados, p.186.

${ }^{247}$ Cf. José Francisco Rezek, Direito dos tratados, p.187-200.

${ }^{248}$ Direito dos tratados, p.226.

${ }^{249}$ Cf. José Francisco Rezek, Direito dos tratados, p.226-228.
} 
depende do regulamento interno da conferência, que poderá prever normas específicas sobre a condução dos debates, as votações, as comissões, entre outros ${ }^{250}$.

Negociações para a celebração de tratado internacional também podem ter lugar em assembléia plenária de organizações internacionais, que, se ordinária, dá-se com a colocação do tema em pauta, distinguindo-se das negociações coletivas comuns unicamente pelo caráter permanente do foro em que se desenvolve; "quanto ao mais, a metodologia negocial pouco tem como variar”251.

A assinatura de um tratado internacional marca o encerramento das negociações e, como conseqüência, acarreta a imutabilidade do texto. Encerram-se as negociações, como dito, mas esta ainda não vincula juridicamente o Estado. Observa Celso de Albuquerque Mello que "a assinatura no período histórico em que predominou a teoria do mandato para os plenos poderes era da maior importância, uma vez que ela obrigava o soberano, que deveria obrigatoriamente ratificar o tratado, a não ser no caso em que o negociador excedesse os poderes recebidos. Todavia, com o desenvolvimento da ratificação como ato discricionário, a assinatura diminuiu consideravelmente de importância”252. Nesse sentido, Guido Soares sustenta que “da assinatura dos tratados, bilaterais ou multilaterais, não defluem, necessariamente, obrigações para os Estados signatários, reafirmando-se que o efeito mais evidente da assinatura é a imutabilidade de seu texto",253.

A assinatura produz igualmente o compromisso da parte de que será a vinculação ao tratado internacional submetida ao órgão (ou aos órgãos estatais) competente para a sua aprovação, segundo o seu direito interno. Esse compromisso é, todavia, político, o quer dizer que a outra parte (ou as outras partes) não pode compelilo a apreciá-lo, segundo o seu direito interno, e muito menos pode compeli-lo a ratificálo.

Rezek, nessa esteira, chama a atenção para os efeitos políticos da assinatura ao afirmar que, "embora não comprometa em definitivo - visto que os tratados multilaterais normalmente não prescindem da ratificação de cada Estado pactuante para obrigá-lo -, a assinatura é algo a cujo respeito os governos contemporâneos têm hesitado mais do que seria razoável, à consideração de que esse ato apenas contribui para garantir a autenticidade do texto que se acabou de negociar no foro multilateral. A

\footnotetext{
${ }^{250}$ Cf. José Francisco Rezek, Direito dos tratados, p.228-233.

${ }^{251}$ Cf. José Francisco Rezek, Direito dos tratados, p.235.

252 Curso, p.214.

${ }^{253}$ Curso, p.69.
} 
não-assinatura por parte do Estado que integrou os trabalhos negociais é um gesto sem significado jurídico, e pretende ter, no plano político, efeito publicitário da insatisfação daquele com o texto acabado, e, pois, de sua consciência da inutilidade de firmar o que seguramente não será ratificado”,254.

Deve-se observar, nesse passo, que são aqui analisados os efeitos da assinatura nos tratados internacionais de direitos humanos. A assinatura, em tratados outros que não de direitos humanos, de caráter executivo, técnico ou administrativo, vincula o Estado. Trata-se do que a doutrina denomina "acordos em forma simplificada” ou “acordos do Executivo": são tratados internacionais que obedecem a processo abreviado, "sobretudo utilizando em acordos bilaterais, que elimina etapas do processo solene (em geral, suprime a aprovação parlamentar e a ratificação)”255. Não se enquadram nesse procedimento simplificado os tratados internacionais de direitos humanos.

Em resumo, tem a assinatura, nos tratados de direitos humanos, a função principal de pôr termo às negociações, atestando a autenticidade do texto do tratado a ser celebrado, bem como a sua imutabilidade, possuindo igualmente outros efeitos, ainda que políticos, tais como o compromisso de submeter seu texto à aprovação, segundo seu direito interno, ou ainda o efeito publicitário da insatisfação com o texto não assinado.

No direito interno brasileiro, por força do artigo 84, incisos VII e VIII, da Constituição, compete privativamente ao Presidente da República “manter relações com Estados estrangeiros e acreditar seus representantes diplomáticos” e “celebrar tratados, convenções e atos internacionais, sujeitos a referendo do Congresso Nacional”. É, dessa forma, competência privativa do Presidente da República participar das negociações e assinar o texto de tratados internacionais, não podendo essa competência ser, em princípio, delegada aos Ministros de Estado, em especial ao Ministro das Relações Exteriores ou ao corpo diplomático do Estado, por força do parágrafo único do mesmo artigo 84 da Constituição.

Essa leitura estrita, todavia, não resiste a uma interpretação sistemática do texto constitucional e não corresponde à prática, pois o Presidente da República não participa e não assina pessoalmente todos os tratados internacionais em nome do Estado brasileiro.

\footnotetext{
${ }^{254}$ Direito dos tratados, p.234.

${ }^{255}$ Cf. Antônio Paulo Cachapuz de Medeiros, O poder de celebrar tratados, p.202-240.
} 
O parágrafo único do artigo 84, de fato, arrola, de maneira taxativa, quais os incisos cujas competências privativas do Presidente da República neles previstos podem ser delegadas, o que acarreta uma primeira conclusão, já aludida acima, de que não seria possível a delegação nos demais incisos desse artigo constitucional. Acontece que as próprias competências previstas nos incisos VII e VIII do artigo 84 da Constituição prevêem, por força própria, a possibilidade de o Presidente da República ser representado por diplomatas nesse mister, independentemente de permissão expressa de seu parágrafo único.

Vicente Marotta Rangel apresenta a questão de maneira ampla. Para o internacionalista, “a competência de realizar todos os atos concernentes à conclusão de tratado internacional cabe aos Chefes de Estado e de Governo e aos Ministros de Relações Exteriores. Essa competência se amplia aos chefes de missões diplomáticas no tocante às convenções celebradas entre os Estados a que pertencem e os Estados em que os representam [sic]; assim como às pessoas acreditadas em conferência internacional ou em órgão de entidade internacional com relação à adoção de texto de tratado por parte dessa conferência ou órgão. Além dessas hipóteses, a competência se estende a pessoas que exibem plenos poderes adequados ou que os venham a ter confirmados pela autoridade competente do Estado a que pertençam»"256.

Sobre o disposto no inciso VII, manifesta-se José Afonso da Silva que "esta é uma função de chefe de Estado que se confere ao presidente da República”. Manter relações com Estados estrangeiros, ainda para Afonso da Silva, "vincula-se com o disposto no art. 21, I, que reconhece competência à União para manter relações com Estados estrangeiros. O texto em consideração complementa aquela competência, atribuindo ao presidente da República seu exercício, como chefe do Estado brasileiro”, já acreditar seus representantes diplomáticos "mostra que os diplomatas credenciados, sejam de comissões permanentes ou temporárias, representam o presidente da República, que é quem tem, como chefe de Estado, a competência primária para representar a República Federativa do Brasil nos atos de relações internacionais”257. “’Acreditar' é a outorga de credencial com que o representante se apresenta perante o

\footnotetext{
${ }^{256}$ Os conflitos entre o direito interno, p.37.

${ }^{257}$ Comentário contextual, p.486-487.
} 
governo estrangeiro ou organismo internacional junto ao qual ele vai exercer o poder de representação" 258 .

Os agentes diplomáticos, dessa forma, por permissão extraída do próprio inciso VII do artigo 84 da Constituição, e não de seu parágrafo único, representam o Presidente da República nas negociações internacionais, assinando, inclusive, esses tratados internacionais.

4.2.2. Envio de Mensagem ao Congresso Nacional: indicação do tratado internacional como de direitos humanos.

Assinado o tratado internacional pelo Poder Executivo, é encaminhada mensagem ao Congresso Nacional pelo Presidente da República. Trata-se, em última análise, da iniciativa desse novo procedimento previsto no bojo do artigo $5^{\circ}$, $\S 3^{\circ}$, da Constituição, não se devendo "aplicar a restrição endereçada às propostas de emenda em geral no tocante à sua iniciativa legislativa, aplicando-se por analogia às propostas de emenda"259.

Valério de Oliveira Mazzuoli descreve o procedimento: “no Legislativo, em primeiro lugar, ocorrerá a recepção da mensagem do Presidente da República, acompanhada de Exposição de Motivos (EM) do Ministro das Relações Exteriores, a ele endereçada, juntamente com o texto de inteiro teor do tratado internacional submetido à apreciação"260.

Inicia-se a tramitação pela Câmara dos Deputados, em aplicação do artigo 64, caput, da Constituição que determina que “a discussão e votação dos projetos de lei de iniciativa do Presidente da República, do Supremo Tribunal Federal e dos Tribunais Superiores terão início na Câmara dos Deputados”.

Nessa Casa do Congresso, primeiramente, dá-se publicidade ao texto do tratado com a sua leitura em plenário, remetendo-o, após, à Comissão de Relações Exteriores. No âmbito dessa Comissão, elabora-se um parecer, que deve apresentar um projeto de decreto legislativo, que será submetido à Comissão de Constituição, Justiça e Redação,

\footnotetext{
${ }^{258}$ Cf. José Afonso da Silva, Comentário contextual, p.487. A doutrina, em geral, aponta como sendo do Poder Executivo, e não do Presidente da República, a competância para celebrar tratados internacionais; nesse sentido, entre outros, Nadia de Araújo, A internalização dos tratados, p.3.

${ }^{259}$ Cf. André Ramos Tavares, Reforma do Judiciário, p.45.

${ }^{260}$ O Poder Legislativo, p.31.
} 
responsável essencialmente pela análise da constitucionalidade do projeto de decreto legislativo e, por conseqüência, do próprio tratado internacional ${ }^{261}$.

A indicação do tratado internacional como de direitos humanos acontece já na mensagem do Presidente da República ao Congresso Nacional, o que deve ser confirmado pelo parecer da Comissão de Relações Exteriores, ao determinar o procedimento pelo qual será apreciado o projeto de decreto legislativo, e, por fim, pela Comissão de Constituição, Justiça e Redação. “Aprovado o projeto pelas Comissões, será ele submetido à votação em plenário”"262.

Por fim, registre-se que, confirmado o projeto de decreto legislativo como de apreciação de um tratado de direitos humanos, deve ele ser aprovado, “em dois turnos, por três quintos dos votos dos respectivos membros”, conforme disposto no artigo $5^{\circ}, \S$ $3^{\circ}$, da Constituição. Após ter sua redação final determinada pela Comissão de Constituição, Justiça e Redação, deve ser ele remetido ao Senado para que o mesmo procedimento seja repetido.

Caso entenda uma dessas Comissões que o tratado internacional não versa sobre direitos humanos, será o projeto de decreto legislativo encaminhado para apreciação pelo procedimento ordinário e, em hipótese de aprovação, não será esse tratado internacional "equivalente às emendas constitucionais”, passando a gozar, por conseqüência, de posição hierárquica infraconstitucional ordinária, conforme doutrina dominante e jurisprudência consolidada do Supremo Tribunal Federal.

\subsubsection{Aprovação pelo Congresso Nacional: participação do Poder Legislativo.}

A participação do Poder Legislativo no procedimento de celebração e de incorporação de tratados internacionais é exigência do processo democrático. Considerando que os tratados internacionais celebrados e incorporados vinculam os indivíduos diretamente, assim como as demais normas jurídicas internas, faz-se necessária a sua aprovação pelos seus representantes, segundo as regras do jogo democrático.

Não foi, todavia, sempre assim. Tem-se notícia do instituto da ratificação desde um dos mais antigos tratados a que faz menção a doutrina; o Poder Legislativo, os representantes do povo, nem sempre participaram dessa etapa da celebração dos

\footnotetext{
${ }^{261}$ Cf. Valério de Oliveira Mazzuoli, O Poder Legislativo, p.31.

${ }^{262}$ Cf. Valério de Oliveira Mazzuoli, O Poder Legislativo, p.31.
} 
tratados. Aponta Celso de Albuquerque Mello, no tratado estabelecido entre Ramsés II, faraó do Egito, e Hattisuli, rei dos Hititas, no ano de 1280 a.C., uma fórmula de ratificação, exercida, porém, pelas pessoas do rei e do faraó ${ }^{263}$. Na Grécia e em Roma, os tratados precisavam do consentimento do Conselho e da Assembléia do povo, no caso grego, e do Senado, no caso romano ${ }^{264}$. Durante a Idade Média, era praticada igualmente a ratificação, que era feita pelo Príncipe, "normalmente, por meio de um juramento"265.

Pode-se perceber que a ratificação, em todos os períodos acima apresentados, apresenta a mesma essência: a confirmação da submissão a determinado tratado pelos que se aponta como titulares do poder constituinte ${ }^{266}$.

No final do século XVIII, com a independência dos Estados Unidos e a Revolução Francesa, rompeu-se com o Absolutismo. O Monarca deixava de personalizar o Estado, passando o Poder Legislativo a exercer papel fundamental na formação da vontade geral, em uma conjugação das idéias de Montesquieu e Rousseau. É nesse contexto que passou o Poder Legislativo a intervir nos assuntos internacionais do Estado, inclusive na celebração e incorporação de tratados internacionais.

João Grandino Rodas leciona que, "por influência das idéias da Revolução Francesa, as constituições passaram a associar os parlamentares na formação dos tratados, instituindo a formalidade da aprovação parlamentar, condição 'sine qua non', para que o poder executivo possa proceder à ratificação ou adesão”267. É o que Celso de Albuquerque Mello denominou processo de “democratização das relações internacionais

No Brasil, “a política externa sempre foi uma área de preocupação relativamente secundária na reflexão teórica e na prática corrente da maior parte dos partidos políticos republicanos”, contudo, “a transição, a partir de 1979, de um sistema bipartidário imperfeito - isto é, deformado pela imposição de um partido artificialmente dominante, impedindo a alternância no poder - para um regime de pluralismo moderado, significou, na vida político-partidária do País, uma maior latitude institucional para a discussão dos temas de política externa no âmbito do Congresso. O encerramento do chamado 'ciclo

\footnotetext{
${ }^{263}$ Ratificação de tratados, p.33-34.

${ }^{264}$ Cf. Celso de Albuquerque Mello, Ratificação de tratados, p.34-40.

${ }^{265}$ Cf. Celso de Albuquerque Mello, Ratificação de tratados, p.40-41.

${ }^{266}$ Pelos que se aponta, modernamente, como titulares do poder constituinte, porque a teoria do poder constituinte é criação moderna.

${ }^{267}$ Tratados internacionais, p.316.

${ }^{268}$ Ratificação de tratados, p.84.
} 
militar’ no processo político nacional representou, ao mesmo tempo, a volta, ao cenário político brasileiro, do velho estilo de negociações interpartidárias nas diversas esferas da estrutura de poder, o que pode vir igualmente a repercutir sobre a comunidade da política exerna”269.

A atribuição de competência ao Congresso Nacional para a aprovação de tratados internacionais está prevista no artigo 49, I, do texto constitucional. Por força desse artigo, “é da competência exclusiva do Congresso Nacional resolver definitivamente sobre tratados, acordos ou atos internacionais que acarretem encargos ou compromissos gravosos ao patrimônio nacional”.

Assim, os tratados devidamente assinados são submetidos ao Congresso Nacional, para a deliberação sobre sua aprovação, ou não. Relata José Afonso da Silva que “a discussão e votação da matéria começam pela Câmara dos Deputados. Recebida a mensagem do presidente da República, o presidente da Câmara submete-a à Comissão de Relações Exteriores, onde se decidirá por sua aprovação ou rejeição. Decidido pela aprovação, o relator elaborará o competente projeto de decreto legislativo a ser submetido ao Plenário, após oitiva da Comissão de Constituição e Justiça, que examinará os aspectos constitucionais do ato" ${ }^{270}$. O ainda projeto de decreto legislativo somente é enviado ao Senado, para discussão e aprovação ou rejeição, se aprovado na Câmara dos Deputados. Ainda segundo José Afonso da Silva, "se a Câmara rejeitar o acordo não caberá remessa ao Senado, porque isso significa rejeitá-lo definitivamente” e, segue o mesmo autor, “o mesmo se diga se o Senado o rejeitar”, concluindo que "o referendo do acordo terá que ser bicameral”271.

Ao exposto por José Afonso da Silva sobre a participação do Congresso Nacional na aprovação dos tratados internacionais em geral, deve-se acrescentar que, com a introdução do $\S 3^{\circ}$ ao artigo $5^{\circ}$ da Constituição pela Emenda Constitucional $n^{o}$ 45/04, para que os tratados de direitos humanos sejam equivalentes às emendas constitucionais, devem eles ser aprovados, “em cada Casa do Congresso Nacional, em dois turnos, por três quintos dos votos dos respectivos membros”. Cumpridos os requisitos do artigo $5^{\circ}, \S 3^{\circ}$, da Constituição, fica aprovado o decreto legislativo; caso contrário, fica ele rejeitado definitivamente. "Promulgado o decreto será o mesmo numerado (pela Secretaria Geral da Mesa do Senado) e publicado no Diário do

\footnotetext{
${ }^{269}$ Cf. Paulo Roberto de Almeida, Relações exteriores, p.114-115.

${ }^{270}$ Cf. José Afonso da Silva, Comentário contextual, p.402.

${ }^{271}$ Cf. José Afonso da Silva, Comentário contextual, p.402.
} 
Congresso Nacional e no Diário Oficial da União"272, tal como acontece com as emendas constitucionais.

Fica evidente, sobre a participação do Poder Legislativo no processo de celebração e de incorporação dos tratados internacionais, nas palavras de Paulo Roberto de Almeida, que "a questão central que se coloca do ponto de vista das relações internacionais do País é a de que o Congresso passa a integrar a estrutura mesma do processo decisório, ampliando consideravelmente seu poder de controle sobre o fluxo corrente das atividades de política externa, em seu sentido mais amplo. Independentemente dos dispositivos constitucionais que venham a ser adotados, uma larga fração dos controles que se pretende impor ao Executivo dependerá, contudo, da própria capacidade do Congresso em acompanhar adequadamente o desempenho da comunidade de política externa, através de suas comissões especializadas e por meio de um staff devidamente preparado"; conclui o autor que "o novo padrão de relacionamento entre os Poderes no campo da política externa ultrapassa assim o âmbito meramente legal-constitucional para projetar-se no campo sócio-político”273.

Algumas questões, por fim, podem ser apontadas com a leitura do dispositivo constitucional.

A primeira delas diz respeito à distinção entre competência privativa e exclusiva. Para os que fazem essa distinção, entre eles José Afonso da Silva ${ }^{274}$, competência exclusiva é a atribuída a uma entidade com exclusão das demais, enquanto privativa é a atribuída igualmente a uma entidade, mas com possibilidade de delegação e de competência suplementar.

Há, contudo, quem advogue a inexistência da distinção no texto constitucional. Fernanda Dias Menezes de Almeida afirma ser válida a classificação das competências assentada no critério da delegação, mas não entende apropriado "extremar mediante o uso dos termos 'privativo’ e ‘exclusivo’ as competências próprias que podem e as que não podem ser delegadas, como se ‘privativo’ não exprimisse, tanto quanto ‘exclusivo’,

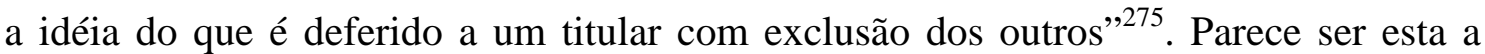
opinião mais consentânea com a Constituição brasileira: determinada competência privativa ou exclusiva prevista no texto constitucional somente é delegável por previsão expressa, independentemente da terminologia utilizada.

\footnotetext{
${ }^{272}$ Cf. Valério de Oliveira Mazzuoli, O Poder Legislativo, p.33.

273 Relações exteriores, p.118.

${ }^{274}$ Curso, p.483.

${ }^{275}$ Competências na Constituição de 1988, p.79.
} 
Outra questão é o sentido da expressão “resolver definitivamente”. É essa expressão do artigo 49, I, da Constituição a responsável por parte da doutrina afirmar, de maneira equivocada, que é atribuição do Congresso Nacional ratificar tratados internacionais.

Heleno Taveira Tôrres sustenta que, “em resumo, o tratado é recepcionado na ordem interna não mediante o ato final - o Decreto do Presidente da República - mas, quando presente o Decreto Legislativo oriundo do Congresso Nacional, tenha-se a respectiva ratificação. Por isso, o início do prazo de vigência da Convenção, a partir do qual os interessados poderão reclamar os compromissos assumidos pelos EstadosPartes, não decorre do ato administrativo que, consuetudinariamente, a título de conferir-lhe publicidade e execução, pretende servir como pressuposto de validade, pelo procedimento. A vigência do acordo começará a contar exclusivamente a partir do ato de ratificação, marco de comprometimento do Estado pelas disposições convencionais, como previsto no corpo do tratado, pela aprovação mediante o Decreto Legislativo expedido pelo Congresso Nacional”276.

Ainda sobre a mesma questão, afirma Roque Antonio Carrazza que “é preciso, em suma, que o Estado brasileiro manifeste sua vontade de inovar a ordem jurídica, por meio do tratado internacional. Ora, o Estado brasileiro manifesta esta vontade por meio da conjugação de vontades de dois de seus Poderes: o Executivo (que firma o tratado) e o Legislativo (que o ratifica). O estado brasileiro não é apenas o Executivo. O estado brasileiro se apresenta, no concerto das Nações, pelo Executivo, mas delibera mediante harmônica atuação deste com o Legislativo”277.

Não parece, contudo, que a expressão "resolver definitivamente” do artigo 49, I, da Constituição atribua ao Congresso Nacional a ratificação dos tratados internacionais. Nesse sentido, José Afonso da Silva aduz que “'resolver definitivamente', no texto, significa apenas que o Congresso Nacional referendará ou não o tratado, acordo ou ato internacional. Não significa que a ele compete a última palavra no assunto, porque após o seu pronunciamento cabe a ratificação, que, como visto, é ato do chefe de Estado”,278.

De fato, interpretando-se sistematicamente os artigos 49, I, e 84, VII e VIII, da Constituição, forçosa é a conclusão de que cabe ao Presidente da República a ratificação de tratados internacionais, e não ao Congresso Nacional. Somente "resolve

\footnotetext{
${ }^{276}$ Aplicação dos tratados, p.150-151.

${ }^{277}$ Curso de direito constitucional tributário, p.202.

${ }^{278}$ Comentário contextual, p.403.
} 
definitivamente” o Congresso Nacional sobre a celebração e incorporação de tratados internacionais pelo Estado brasileiro na hipótese de rejeição. Com a rejeição do Congresso Nacional, resolve ele definitivamente pela não celebração e pela conseqüente não incorporação do tratado internacional; com a rejeição do Congresso Nacional, não pode o Presidente da República ratificar o tratado internacional.

Assim pondera Fernanda Dias Menezes de Almeida, para quem “será do Congresso a última palavra, caso este desaprove o tratado, sendo óbvio que sua aprovação dá ensejo à continuidade do processo de incorporação com as providências da alçada do Executivo"279.

Em sentido idêntico, afirma Valério de Oliveira Mazzuoli que “o Congresso Nacional, por conseguinte, só resolve definitivamente sobre os tratados quando rejeita o acordo, ficando o Executivo, neste caso, impedido de ratificá-lo”280. Aprovado o tratado internacional, há edição de decreto legislativo; rejeitado o tratado, não há edição desse decreto, “caso em que apenas se comunica a decisão, mediante mensagem, ao Chefe do Poder Executivo"281.

Outra interpretação pode ainda ser atribuída à expressão “resolver definitivamente”. A necessidade de aprovação de denúncia a tratado internacional pelo Congresso Nacional tem como um de seus argumentos esse dispositivo previsto no artigo 49, I, da Constituição, como será tratado em momento oportuno.

Ainda sobre essa prescrição constitucional, questão interessante é a da abrangência da necessidade de aprovação de tratados internacionais pelo Poder Legislativo. A expressão utilizada pelo legislador constituinte é "tratados, acordos e atos internacionais que acarretem encargos ou compromissos gravosos ao patrimônio nacional”. A questão, de fato, é bastante interessante, mas foge ao escopo deste trabalho, pois não se afirma desnecessária a aprovação, pelo Legislativo, dos tratados internacionais de direitos humanos, quando se discorre acerca dos acordos do Executivo ou acordos em forma simplificada e, por outro lado, não se tem notícia de questionamentos sobre se esses tratados acarretam "encargos ou compromissos gravosos ao patrimônio nacional”.

Por fim, deve-se analisar a hipótese de o projeto de decreto legislativo não alcançar a votação necessária prescrita pelo artigo $5^{\circ}$, $\S 3^{\circ}$, da Constituição. Parece claro

\footnotetext{
${ }^{279}$ A incorporação dos tratados, p.51.

${ }^{280}$ O Poder Legislativo, p.23.

${ }^{281}$ Cf. Valério de Oliveira Mazzuoli, O Poder Legislativo, p.17.
} 
que há uma distinção substancial entre os procedimentos de aprovação dos tratados em geral e dos tratados internacionais de direitos humanos, não existindo parâmetros para a possibilidade de um projeto de decreto legislativo relativo a um tratado de direitos humanos que não cumprir os requisitos do artigo $5^{\circ}, \S 3^{\circ}$, ser considerado aprovado pelo procedimento ordinário, de aprovação dos demais tratados internacionais. Em outras palavras, não há somente uma distinção de “maiorias” necessárias para a aprovação, sendo uma simples e outra qualificada, mas, sim, há dois procedimentos distintos.

Assim, o que determina a qual procedimento deve ser submetido o projeto de decreto legislativo é a o que está apontado na mensagem do Presidente da República, acompanhada da exposição de motivos do Ministro das Relações Exteriores, que serão analisadas, em conjunto, pelas Comissões da Câmara e do Senado, em especial pelas Comissões de Relações Exteriores e de Constituição, Justiça e Redação.

Submetido o projeto de decreto legislativo, por se referir a tratado considerado de direitos humanos, ao procedimento do artigo $5^{\circ}$, $\S 3^{\circ}$, da Constituição, surgem tãosomente duas opções: pode ele ser aprovado ou rejeitado. Não há parâmetros para se afirmar a sua aprovação por procedimento mais simples, autorizando-se o Presidente a ratificá-lo, mas com posição hierárquica não equivalente à das emendas constitucionais. Igualmente, um projeto de decreto legislativo, por não se referir a tratado considerado de direitos humanos, submetido ao procedimento ordinário, pode ou não ser aprovado; não há possibilidade de um projeto de decreto legislativo aprovado, por exemplo, por unanimidade, autorizar o Presidente da República a ratificar o tratado, mas com posição hierárquica equivalente à das emendas constitucionais.

Pode ocorrer, contudo, que um tratado internacional de direitos humanos, por qualquer motivo, seja submetido à aprovação pelo procedimento ordinário. Isso evidencia a não obrigatoriedade de submissão dos tratados de direitos humanos ao procedimento previsto no artigo $5^{\circ}, \S 3^{\circ}$, da Constituição. Submetido um tratado de direitos humanos ao procedimento ordinário, há, novamente, apenas duas opções: pode ele ser rejeitado, hipótese em que não fica autorizado o Presidente da República a ratificá-lo, ou pode ser ele aprovado, hipótese em que, se ratificado, gozará de posição hierárquica infraconstitucional ordinária. O inverso não é verdadeiro: não pode haver a submissão de tratado internacional que não de direitos humanos ao procedimento previsto no artigo $5^{\circ}, \S 3^{\circ}$, da Constituição, pois, nessa hipótese, padeceria o decreto legislativo do vício da inconstitucionalidade. 
Nesse sentido, afirmam Gilmar Ferreira Mendes, Inocêncio Mártires Coelho e Paulo Gustavo Gonet Branco que, “a partir da Emenda Constitucional n. 45/2004, passou-se, entretanto, a admitir que os tratados 'que forem aprovados, em cada Casa do Congresso Nacional, em dois turnos, por três quintos dos votos dos respectivos membros, serão equivalentes às emendas constitucionais’. Nesses casos, e apenas nesses, essas normas gozarão de status constitucional. A emenda não parece impedir que se opte pela aprovação de tratado sobre direitos humanos pelo procedimento comum, com o que se facilitará o seu ingresso no ordenamento brasileiro, valendo como norma infraconstitucional”282.

Soraya Santos Lopes sustenta que “a redação do $\S 3^{\circ}$ não dispõe que os tratados e convenções internacionais ingressarão obrigatoriamente na ordem interna com status de Emenda Constitucional. O quorum qualificado, obtido por três quintos dos votos, em cada Casa do Congresso Nacional, não é uma imposição, mas uma faculdade, já que a redação não insere a locução 'serão aprovadas', mas tão-somente 'que forem aprovadas', sinalizando uma faculdade e não a imperatividade para que o Congresso Nacional submeta a matéria à aprovação em dois turnos, por três quintos dos votos dos respectivos membros. Assim, a matéria que tenha por objeto os direitos humanos poderá ou não ser incorporada como emenda constitucional. A matéria que foge ao âmbito dos direitos humanos continuará sendo objeto de ratificação interna, mas ingressará no ordenamento com status de norma infraconstitucional, especificamente lei ordinária”283.

Em suma, no direito brasileiro, cabe ao Congresso Nacional aprovar os tratados internacionais de direitos humanos, em obediência ao procedimento do artigo $5^{\circ}$, $\S 3^{\circ}$, para que o tratado seja equivalente à emenda constitucional. Uma vez submetido a esse procedimento, há somente duas possibilidades: o tratado é aprovado e está o Presidente da República autorizado a ratificá-lo ou o tratado não é aprovado e não pode o Presidente concluir o procedimento de celebração. Caso haja a submissão de um tratado de direitos humanos ao procedimento ordinário, com a sua aprovação gozará ele de posição hierárquica infraconstitucional ordinária.

\subsubsection{Ratificação do tratado internacional pelo Poder Executivo.}

\footnotetext{
${ }^{282}$ Curso, p.216-217.

${ }^{283}$ A efetividade dos direitos humanos, p.286. André Ramos Tavares, Reforma do Judiciário, p.43, por sua vez, sustenta a obrigatoriedade do novo rito.
} 
Aprovado o tratado internacional, por meio de decreto legislativo, pelo Congresso Nacional, está o Presidente da República autorizado a ratificar o tratado internacional; passa-se, assim, à última etapa do procedimento de celebração. A ratificação é o ato que, afinal, vincula o Estado ao tratado, no âmbito do direito internacional.

No direito brasileiro, cabe igualmente ao Presidente da República, por força do artigo 84, VII e VIII, da Constituição, a ratificação dos tratados internacionais de direitos humanos.

Ratificação, nas palavras de José Francisco Rezek, “é o ato unilateral com que o sujeito de direito internacional, signatário de um tratado, exprime definitivamente, no plano internacional, sua vontade de obrigar-se”284. Segundo Celso de Albuquerque Mello, “a ratificação é talvez a mais importante das fases na conclusão dos tratados internacionais, uma vez que é dela que dependerá a obrigatoriedade dos acordos internacionais,

Afirma Celso de Albuquerque Mello que “a doutrina mais recente e a prática internacional têm sido unânimes” com relação à natureza discricionária da ratificação. Aponta o internacionalista que disso decorrem duas conseqüências: a indeterminação do prazo para a ratificação e a licitude de sua recusa ${ }^{286}$.

A discricionariedade da ratificação merece ser analisada em duas dimensões, uma internacional e outra interna. Na dimensão internacional, não está o Estado signatário de um determinado tratado internacional obrigado e ratificá-lo. Essa discricionariedade decorre diretamente de sua soberania, afinal, o Estado somente se vincula a determinado tratado internacional se for de sua vontade.

Por outro lado, em sua dimensão interna, a ratificação é ato discricionário do Poder Executivo em relação ao Poder Legislativo.

A expressão “resolver definitivamente”, presente no artigo 49, I, da Constituição, poderia levar à conclusão de que, aprovado o decreto legislativo pelo Legislativo, estaria a decisão de ratificação desse tratado internacional "resolvida definitivamente”, mas uma interpretação sistemática do texto constitucional leva a conclusão distinta: é discricionária a competência do Presidente da República para ratificar, ou não, tratados internacionais, após a aprovação do Poder Legislativo.

\footnotetext{
${ }^{284}$ Direito dos tratados, p.267.

${ }^{285}$ Ratificação de tratados, p.57.

${ }^{286}$ Ratificação de tratados, p.67.
} 
Celso de Albuquerque Mello sustenta que “a ratificação é um ato discricionário do estado e, dentro dele, do Poder Executivo; o Congresso pode aprovar um tratado e o Executivo pode se recusar a ratificá-lo”287, ao passo que Nadia de Araújo afirma que “a ratificação é manifestação, também de cunho discricionário do Poder Executivo, no sentido de que o propósito de pactuar o tratado continua firme, atendendo aos interesses superiores do Estado",288.

Nesse mesmo sentido, aduz Fernanda Dias Menezes de Almeida que "a aprovação do Congresso autoriza o Presidente da República a passar para a fase seguinte, a da ratificação do tratado. Autoriza, mas não o obriga, fique isto claro, pois a decisão de ratificar o acordo é só dele, Presidente, que poderá deixar de fazê-lo, se entender que é o caso, depois de melhor analisar a matéria”289.

\subsubsection{Adesão ao tratado internacional pela República Federativa do Brasil.}

Outra maneira pela qual pode a República Federativa do Brasil vincular-se a um tratado internacional é a adesão. Trata-se, pois, de forma de expressão de consentimento em relação a determinado tratado internacional.

Segundo José Francisco Rezek, "sua natureza jurídica não difere daquela da ratificação: também aqui o que temos é manifestação firme da vontade de ingressar no domínio jurídico do tratado. O aderente é, em princípio, um Estado que não negociou nem assinou o pacto - e que dessarte não pode ratificá-lo -, mas que, tomado de interesse por ele, decide tornar-se parte, havendo-se antes certificado da possibilidade do ingresso por adesão"290.

A certificação da possibilidade do ingresso por adesão, mencionada por Rezek, refere-se, indubitavelmente, à aprovação pelo Poder Legislativo; surgindo interesse na adesão a determinado tratado internacional, deve o Presidente da República enviar mensagem ao Congresso Nacional, seguindo-se, a partir desse momento, o mesmo procedimento descrito anteriormente. Da mesma maneira que é necessária a aprovação de tratado internacional pelo Legislativo para que possa o Executivo ratificá-lo, faz-se

\footnotetext{
${ }^{287}$ Ratificação de tratados, p.70.

${ }^{288}$ A internalização dos tratados, p.3.

${ }^{289}$ A incorporação dos tratados, p.51.

${ }^{290}$ Direito dos tratados, p.417. Rezek registra ainda que, “em casos não exatamente comuns, o aderente é um Estado que negociou e firmou o pacto, mas que, tendo perdido o prazo para ratificá-lo, vale-se da oportunidade aberta aos não-signatários para tornar-se parte mediante adesão”, dando como exemplo o Brasil, no caso das Leis Uniformes de Genebra sobre títulos de crédito.
} 
mister a aprovação de tratado internacional a que pretende aderir a República Federativa do Brasil.

Aprovado o decreto legislativo, surge para o Presidente da República a faculdade de “exprimir-se num gesto único e definitivo”, com “a apresentação, a quem de direito, da carta ou instrumento representativo da vontade estatal de ser parte no tratado",291. A carta ou instrumento de adesão, segundo Rezek, “tem o mesmo teor jurídico da carta de ratificação”292 e nesses termos deve repousar a sua análise.

4.3. Incorporação dos tratados internacionais de direitos humanos ao direito interno brasileiro.

Celebrado o tratado internacional de direitos humanos pela República Federativa do Brasil, seja pela ratificação, naqueles em que o Estado brasileiro participara de sua formação desde as negociações, seja pela adesão, nos que a República tão-somente aderiu a seu texto, passa-se ao procedimento de incorporação desse ato normativo internacional ao direito interno brasileiro.

Essa seqüência dos procedimentos tem uma explicação lógica: até o término do procedimento de celebração do tratado internacional, este ainda não vincula a República Federativa do Brasil. Como visto, um tratado internacional de direitos humanos somente passa a vincular o Estado brasileiro com a ratificação ou com a adesão; antes disso, o tratado internacional pode até ter força vinculante no direito internacional, vinculando outros Estados, mas para República Federativa do Brasil ele ainda não tem essa força ${ }^{293}$, e, em razão disso, não faz sentido incorporá-lo.

É desse procedimento de incorporação dos tratados internacionais de direitos humanos que trata este item.

4.3.1. Desnecessidade de promulgação e publicação dos tratados internacionais de direitos humanos por meio de decreto do Executivo.

\footnotetext{
${ }^{291}$ Direito dos tratados, p.424.

${ }^{292}$ Direito dos tratados, p.425.

${ }^{293}$ Essa possibilidade é mais facilmente visualizada na adesão, pois nela a República Federativa do Brasil vincula-se a tratado internacional já em plena vigência anteriormente. Nas hipóteses de ratificação, isso também pode acontecer, no tratados que, por exemplo, prevêem para a sua entrada em vigor a ratificação de dez ratificações e o Estado brasileiro é o vigésimo a ratificá-lo, após alguns meses da sua décima ratificação.
} 
“No direito brasileiro, desde a decisão do Supremo Tribunal Federal, em seu Recurso Extraordinário $n^{0} 71.154-\mathrm{PR}^{294}$, não mais se sustenta a tese da necessidade de promulgação de uma lei, em sentido estrito, que reproduza o conteúdo dos tratados internacionais, para que estes sejam aplicados no direito interno, o que indicaria a adoção do denominado dualismo. Decidiu, na ocasião, o Ministro relator Oswaldo Trigueiro, 'quanto ao direito brasileiro, não me parece razoável que a validade dos tratados fique condicionada à dupla manifestação do Congresso, exigência que nenhuma das nossas Constituição jamais prescreveu'. Sobre o precedente, manifestou-se Luiz Flávio Gomes que 'desde então, é absolutamente tranqüilo entre nós o entendimento de que não é necessária a aprovação de uma lei formal para a incorporação dos tratados no nosso ius positum, $295,296$.

Vale lembrar que o Supremo Tribunal Federal, já em 1943, na Apelação Cível no 7872/43, em voto do Ministro Philadelpho Azevedo, decidiu que, “entre nós, a formação dos tratados, após a fase precontratual, das negociações, se assemelha à das leis, exigindo pronunciamento do Poder Legislativo, promulgação e publicação, sujeita esta às normas gerais para a vigência”297.

O ato de execução de que se trata não é, pois, uma lei em sentido estrito, que reproduz o conteúdo do tratado internacional de direitos humanos celebrado pela República Federativa do Brasil, mas, sim, um decreto do Presidente da República que, após aprovado o tratado pelo Legislativo e ratificado pelo mesmo Presidente, promulga e publica o tratado internacional para que este tenha aplicabilidade interna.

Há duas linhas argumentativas distintas que levariam à desnecessidade de promulgação e publicação dos tratados internacionais de direitos humanos por meio de decreto do Executivo. Como apontamos em trabalho anterior, "uma delas que sustenta a desnecessidade, após a ratificação, de um ato de execução para todo e qualquer tratado internacional ser aplicado no âmbito do direito interno, e uma segunda que sustenta esta desnecessidade tão somente para os tratados internacionais de direitos humanos”298.

A primeira delas, a que sustenta a desnecessidade de promulgação e publicação de todo e qualquer tratado internacional, inclusive os de direitos humanos, sustenta que

\footnotetext{
${ }^{294} \mathrm{RE} \mathrm{n}^{\circ}$ 71.154-PR, de 4 de agosto de 1971, publicado na RTJ 58/70.

${ }^{295}$ A questão, p.23. Houve, no entanto, na doutrina nacional, quem já sustentou a necessidade de promulgação de lei para que o tratado fosse aplicado; cf. Amílcar de Castro, Direito internacional privado, p.123-124.

${ }^{296}$ Cf. Marco Antonio Corrêa Monteiro, O impacto, p.15.

297 Apelação Cível nº7872, p.19.

${ }^{298}$ Cf. Marco Antonio Corrêa Monteiro, O impacto, p.17.
} 
“a Constituição brasileira, ao tratar do procedimento de incorporação dos tratados pela ordem interna, não exigiu a edição de nenhum ato de execução para que estes atos tenham vigência interna”299.

Contra a necessidade de edição de decreto do Executivo para os tratados internacionais em geral manifesta-se José Carlos de Magalhães. Aduz o internacionalista, após dissertar sobre a corrente que sustenta a necessidade do decreto, que “a Constituição, no entanto, não dispõe em qualquer artigo que os tratados, para terem vigência no país, dependem dessa providência - promulgação por meio de decreto do Presidente da República - que a praxe consagrou, mas que não encontra suporte constitucional que a torne obrigatória. Segundo o art. 59 da Constituição Federal, o processo legislativo compreende: I) a elaboração de emendas à Constituição; II) leis complementares; III) leis ordinárias; IV) leis delegadas; V) medidas provisórias; VI) decretos legislativos e VII) resoluções”. E, segue o internacionalista, "não há referência alguma a tratado e muito menos a decreto do Executivo, que é o meio pelo qual esse Poder regulamenta leis ou expede ordens que vinculam a administração federal, como se verifica no art. 84, IV, da Constituição. O Congresso, ao ratificar o tratado, o faz por meio de decreto legislativo, pondo-o em vigor no país, não havendo necessidade do decreto de promulgação pelo Executivo, providência não prevista na Constituição”300.

Posicionamento igualmente contrário adota Heleno Taveira Tôrres, ao afirmar que "parece não ser aceitável que um tratado, elaborado pelas autoridades competentes, segundo a designação constitucional e a aquiescência internacional, devidamente autenticado e assinado, reconhecido pelo Poder Legislativo, pelo referendo atribuído pelo Decreto Legislativo, com ulterior publicação deste, e ratificado, gerando o compromisso da República Federativa do Brasil na ordem internacional, perante outra ou várias nações signatárias, apesar de tudo isso, tenha que ficar à mercê de um ato administrativo, o Decreto do Presidente da República. A prevalecer esse critério, o tratado, após sua ratificação, vigoraria apenas no plano internacional, sem gerar efeitos no plano interno, o que colocaria o Brasil na privilegiada posição de poder exigir a observância do pactuado pelas outras partes contratantes, sem ficar sujeito à obrigação

\footnotetext{
${ }^{299}$ Cf. Marco Antonio Corrêa Monteiro, O impacto, p.17.

${ }^{300}$ O Supremo Tribunal Federal e o direito internacional, p.73.
} 
recíproca, atribuindo os respectivos direitos aos destinatários do seu conteúdo, ou realizando os deveres ali estabelecidos" ${ }^{301}$.

Dessa forma, sustentando-se a desnecessidade de promulgação e publicação dos tratados internacionais em geral por meio de decreto do Executivo, estar-se-ia, por conseqüência, sustentando a desnecessidade da edição desse decreto para a incorporação dos tratados internacionais de direitos humanos. A aplicação de todo e qualquer tratado internacional estaria condicionada, após a sua ratificação, tão-somente às suas próprias regras de vigência.

Para a segunda linha argumentativa, sustenta-se especificamente a desnecessidade de promulgação e publicação dos tratados internacionais de direitos humanos. "Para a segunda linha, cabe ressaltar que não negam os seus defensores a necessidade de um ato de execução para que os tratados internacionais em geral sejam incorporados ao direito interno. Não o negam, fique bem claro, para os tratados internacionais em geral. No entanto, afirmam que existe uma especificidade quando se trata da relação entre o ordenamento interno brasileiro e os tratados internacionais sobre direitos humanos; especificidade esta que dispensaria a promulgação deste ato de execução: os tratados de direitos humanos, com sua ratificação, passariam a ser aplicados no âmbito territorial do direito interno de maneira direta e imediata”302.

Até o advento da Emenda Constitucional $n^{0}$ 45/04, sustentava-se a desnecessidade de edição de decreto do Executivo para os tratados internacionais de direitos humanos unicamente no artigo $5^{\circ}, \S 1^{\circ}$, da Constituição, interpretado em um contexto de democratização da República Federativa do Brasil ${ }^{303}$.

Sobre o artigo $5^{\circ}$, §1 ${ }^{\circ}$, da Constituição, manifesta-se Antônio Augusto Cançado Trindade que, "se, para os tratados internacionais em geral, tem-se exigido a intermediação pelo Poder Legislativo de ato com força de lei de modo a outorgar a suas disposições vigência ou obrigatoriedade no plano do ordenamento jurídico interno, distintamente, no tocante aos tratados de direitos humanos em que o Brasil é Parte, os direitos fundamentais neles garantidos passam, consoante os artigos 5(2) e 5(1) da Constituição Brasileira de 1988, a integrar o elenco dos direitos constitucionalmente

\footnotetext{
${ }^{301}$ Aplicação dos tratados, p.150.

${ }^{302}$ Cf. Marco Antonio Corrêa Monteiro, O impacto, p.19.

${ }^{303}$ Cf. Flávia Piovesan, Direitos humanos, p.52.
} 
consagrados e direta e imediatamente exigíveis no plano de nosso ordenamento jurídico interno (...)”304.

Nesse mesmo sentido, afirma Flávia Piovesan que "não será mais possível a sustentação da tese de que com a ratificação os tratados obrigam diretamente aos Estados, mas não geram direitos subjetivos para os particulares, enquanto não advier a referida intermediação legislativa. Vale dizer, torna-se possível a invocação imediata de tratados e convenções de direitos humanos, dos quais o Brasil seja signatário, sem a necessidade de edição de ato com força de lei, voltado à outorga de vigência interna aos acordos internacionais”. E, complementa a autora, “a incorporação automática do Direito Internacional dos Direitos Humanos pelo Direito brasileiro - sem que se faça necessário um ato jurídico complementar para a sua exigibilidade e implementação traduz relevantes conseqüências no plano jurídico. De um lado, permite ao particular a invocação direta dos direitos e liberdades internacionalmente assegurados e, por outro, proíbe condutas e atos violadores a estes mesmos direitos, sob pena de invalidação. Conseqüentemente, a partir da entrada em vigor do tratado internacional, toda norma preexistente que seja com ele incompatível perde automaticamente a vigência. Ademais, passa a ser recorrível qualquer decisão judicial que violar as prescrições do tratado - eis aqui uma das sanções aplicáveis na hipótese de inobservância dos tratados” 305.

Valério de Oliveira Mazzuoli, por sua vez, referindo-se aos tratados de direitos humanos, aduz que, “atribuindo-lhes a Constituição a natureza de 'normas constitucionais', passam os tratados, no mandamento do $\S 1^{\circ}$ do artigo $5^{\circ}$ da $\mathrm{CF}$, a ter aplicabilidade imediata, dispensando-se, assim, a edição de decreto de execução para que irradiem seus efeitos tanto no plano interno como no plano internacional’306.

Em suma, por força do artigo $5^{\circ}, \S 1^{\circ}$, da Constituição, a aplicabilidade dos tratados internacionais de direitos humanos independeriam de promulgação e publicação por meio de decreto do chefe do Poder Executivo.

A desnecessidade de promulgação e publicação dos tratados internacionais por meio de decreto do Executivo, fundamentada unicamente no artigo $5^{\circ}, \S 1^{\circ}$, da Constituição, não convence. Esse dispositivo constitucional, na verdade, não tem a amplitude que se lhe pretende atribuir. Fernanda Dias Menezes de Almeida ensina que “não há, não há mesmo, como extrair do artigo $5^{\circ}, \S 1^{\circ}$, permissivo que dispense os

\footnotetext{
${ }^{304}$ A proteção internacional, p.140.

${ }^{305}$ Direitos humanos, p.99.

${ }^{306}$ A influência dos tratados internacionais, p.94.
} 
tratados de direitos humanos do processo normal de incorporação a que se submetem os demais tratados. Esse dispositivo cuida da aplicação imediata de normas que definam direitos e garantias fundamentais, obviamente de normas que integrem nosso ordenamento jurídico. Mas nem de leve o constituinte trata aí do modo como normas sobre direitos humanos, de matriz internacional, passam a integrar esse ordenamento"307.

Superada a interpretação que se pretendia atribuir ao artigo $5^{\circ}, \S 1^{\circ}$, da Constituição, até o advento da emenda constitucional $\mathrm{n}^{\circ} 45 / 04$, prevalecia 0 entendimento pela necessidade da edição do decreto do Executivo para a promulgação e publicação dos tratados internacionais de direitos humanos.

Luiz Flávio Gomes é taxativo ao afirmar que “a simples ratificação, no entanto, não basta para a vigência do tratado, pois ainda é necessário sua promulgação por Decreto presidencial e publicação, ${ }^{308}$.

José Francisco Rezek, sobre o assunto, afirma que “o ordenamento jurídico, nesta república, é integralmente ostensivo. Tudo quanto o compõe - resulte de produção legislativa internacional ou doméstica - presume publicidade oficial e vestibular. Um tratado regularmente concluído depende dessa publicidade para integrar o acervo normativo nacional, habilitando-se ao cumprimento por particulares e governantes, e à garantia de vigência pelo judiciário. Não faz sentido, no Brasil, a idéia de que a publicidade seja dispensável quando o fiel cumprimento do pacto internacional possa ficar a cargo de limitado número de agentes do poder público: mais ainda que a do particular, a conduta do governante e do servidor do Estado pressupõe base jurídica apurável pelo sistema de controle recíproco entre poderes, e, dessarte, jamais reservada ao conhecimento exclusivo dos que ali pretendem fazer repousar a legitimidade de seu procedimento" $^{309}$.

E segue o internacionalista acrescentando que "no Brasil se promulgam, por decreto do presidente da República, todos os tratados que tenham feito objeto de aprovação congressional. Publicam-se apenas, no Diário Oficial da União, os que hajam prescindido do assentimento parlamentar e da intervenção confirmatória do chefe de Estado. No primeiro caso, o decreto de promulgação não constitui reclamo constitucional: ele é produto de uma praxe tão antiga quanto a Independência e os

\footnotetext{
${ }^{307}$ A incorporação dos tratados, p.57.

${ }^{308}$ A questão da obrigatoriedade, p.28.

${ }^{309}$ Direito internacional público, p.78-79.
} 
primeiros exercícios convencionais do Império. Cuida-se de um decreto, unicamente porque os atos do chefe de Estado costumam ter esse nome. Por mais nada. Vale aquele como ato de publicidade da existência do tratado, norma jurídica de vigência atual ou iminente. Publica-os, pois, o órgão oficial, para que o tratado - cujo texto completo vai em anexo - se introduza na ordem legal, e opere desde o momento próprio”310.

Ainda sobre a praxe constitucional, afirma João Grandino Rodas que “o Brasil, após a Independência, continuou a seguir a tradição lusitana de promulgar os tratados já ratificados por meio de um decreto do Executivo. Embora as Constituições brasileiras da República não façam qualquer referência, esse costume vem sendo mantido"311. Vicente Marotta Rangel, no mesmo sentido, registra que “ainda que não esteja prevista no texto constitucional, a promulgação é uma praxe desde 1826, por ocasião do primeiro tratado concluído pelo Império do Brasil”.

Esse era o entendimento que prevalecia, acertadamente, até o advento da emenda constitucional $n^{0} 45 / 04$. Contudo, entendimento diverso deve ser agora adotado com a determinação do artigo $5^{\circ}, \S 3^{\circ}$, do texto constitucional. Prescreve esse dispositivo constitucional que "os tratados e convenções internacionais sobre direitos humanos que forem aprovados, em cada Casa do Congresso Nacional, em dois turnos, por três quintos dos votos dos respectivos membros, serão equivalentes às emendas constitucionais”.

O ponto central está na expressão "serão equivalentes às emendas constitucionais”. Normalmente, ao analisar-se esse dispositivo constitucional, dá-se grande atenção às suas conseqüências para a posição hierárquica dos tratados internacionais de direitos humanos aprovados pelo procedimento nele previsto, o que será feito em momento ulterior, mas essas não são as únicas decorrências da expressão. $\mathrm{O}$ artigo $5^{\circ}, \S 3^{\circ}$, da Constituição traz igualmente conseqüências procedimentais aos tratados internacionais de direitos humanos aprovados conforme o seu conteúdo.

Esse dispositivo constitucional trata, expressamente, de uma das fases do procedimento de celebração dos tratados internacionais de direitos humanos, a apreciação pelo Poder Legislativo, ao prescrever a necessidade de aprovação “em cada Casa do Congresso Nacional, em dois turnos, por três quintos dos votos dos respectivos membros”, mas não faz referência ao procedimento de incorporação desses tratados, que se segue, como vimos anteriormente, ao procedimento de celebração desses

${ }^{310}$ Direito internacional público, p.79.

${ }^{311}$ A Constituinte, p.50. 
tratados, e com ele não se confunde. Determina, por fim, esse dispositivo constitucional uma conseqüência jurídica aos tratados e convenções internacionais de direitos humanos que cumprirem o procedimento descrito: a sua equivalência às emendas constitucionais.

Em outras palavras, o artigo $5^{\circ}, \S 3^{\circ}$, da Constituição atribui conseqüências jurídicas aos tratados internacionais de direitos humanos que, ao término do procedimento de celebração, terem sido aprovados, em cada Casa do Congresso, em dois turnos, por três quintos dos votos dos respectivos membros, e essas conseqüências são condensadas na prescrição "serão equivalentes às emendas constitucionais”. Em razão disso, tudo o que decorrer da aprovação do decreto legislativo, que finaliza o procedimento de celebração dos tratados internacionais de direitos humanos, deverá “ser equivalente às emendas constitucionais”, inclusive o procedimento de incorporação e a posição hierárquica desses tratados internacionais de direitos humanos.

Por força do artigo 60, § $3^{\circ}$, da Constituição, “a emenda à Constituição será promulgada pelas Mesas da Câmara dos Deputados e do Senado Federal, com o respectivo número de ordem”. O Presidente da República, assim, não participa da promulgação e da publicação das Emendas Constitucionais. Assim deve ser também com os tratados internacionais de direitos humanos que, aprovados pelo procedimento previsto pelo artigo $5^{\circ}$, § $3^{\circ}$, “são equivalentes às emendas constitucionais”.

Nesse sentido, leciona André Ramos Tavares que “cumpre saber, agora, se o processo próprio das propostas de emenda incidirá sobre o $\S 3^{\circ}$ do art. $5^{\circ}$ da CB. A necessidade de coerência faz com que a resposta seja positiva. Isto porque, se suas vestes são as de uma emenda constitucional, as formalidades impingidas a esta deverão ser, também, impostas na novel previsão processual” e afirma o autor que, "sendo assim, essa conclusão leva a outra: a presença do Presidente da República, enquanto chefe de Estado, reduzir-se-á à celebração do tratado internacional (fica excluído do ato de promulgação e publicação e do posterior controle por meio de decreto presidencial, como ocorre em relação aos tratados gerais)” ${ }^{312}$.

Por fim, deve-se discutir se há violação da segurança jurídica com a adoção do procedimento exposto. Acreditamos que não, por um simples motivo: o tratado internacional de direitos humanos será, sim, promulgado e publicado; somente não o será pelo Presidente da República. É atribuição das Mesas da Câmara dos Deputados e

${ }^{312}$ Reforma, p.46. 
do Senado a promulgação e publicação desses tratados internacionais de direitos humanos, mediante promulgação e publicação do respectivo decreto legislativo. Assim acontece com as Emendas Constitucionais e nem por isso afirma-se que há insegurança jurídica nesse procedimento.

Conclui-se, pelo exposto, que não há necessidade de promulgação e publicação dos tratados internacionais de direitos humanos aprovados pelo procedimento previsto no artigo $5^{\circ}, \S 3^{\circ}$, da Constituição, sendo a incorporação, pois, automática por força desse dispositivo constitucional, e não por força do artigo $5^{\circ}$, $\S 1$, da Constituição. Promulgado e publicado o decreto legislativo, juntamente com o texto do tratado internacional, pelas Mesas da Câmara dos Deputados e do Senado, finalizam-se todas as etapas internas de celebração e está o Presidente da república autorizado a finalizar esse procedimento no âmbito internacional, pela ratificação ou pela adesão, com o que poderá o ato normativo internacional ser aplicado no âmbito interno, automaticamente, sem necessidade de novo decreto do Executivo.

4.4. Entrada em vigor na ordem jurídica internacional e na ordem jurídica interna.

Há que se determinar, inicialmente, que os tratados internacionais de direitos humanos, por serem atos normativos com fundamento no direito internacional, após serem incorporados ao direito interno passam a ter novo fundamento de validade, agora de direito interno, mas sem se desvincular de seu fundamento inicial. Assim, por se tratar de um mesmo ato normativo (pois é o tratado internacional que tem eficácia interna), têm íntima relação os planos de existência, validade e eficácia desses tratados internacionais, no direito interno e no direito internacional.

Como visto anteriormente, o tratado internacional é aprovado pelo Legislativo com a promulgação e publicação do decreto legislativo, juntamente com o texto do tratado, no Diário Oficial, preservando-se, assim, a segurança jurídica. Terminada essa fase do procedimento de celebração do tratado internacional, está autorizado o Presidente da República a ratificá-lo, com o que pode esse tratado ser aplicado automaticamente no âmbito interno.

Ratificado o tratado internacional, não há, em princípio, mais entraves para a aplicação desse tratado. O tratado internacional de direitos humanos passa a ser integralmente aplicado no âmbito interno. Contudo, há hipóteses em que o próprio 
tratado internacional apresenta limitações a sua eficácia: por vezes, prevê o texto do tratado um mínimo de ratificações para que ele possa produzir efeitos, ou ainda pode o tratado prever um lapso temporal após a sua assinatura para que ele possa produzir efeitos, entre outros. As possibilidades são inúmeras, por um simples motivo: a liberdade contratual internacional depende unicamente da criatividade das partescontratantes, desde que contida nos limites da licitude.

Assim, um tratado internacional de direitos humanos ratificado pela República Federativa do Brasil traz consigo as suas limitações internas de eficácia e somente após serem elas superadas é que o tratado passa a ser plenamente eficaz no âmbito estatal interno. Observa-se aqui, claramente, uma influência direta entre os planos interno e internacional.

A recíproca também pode ser verdadeira, pois a eficácia de um tratado internacional de direitos humanos no âmbito interno pode influenciar a sua eficácia no âmbito internacional. Assim pode ser, por exemplo, um tratado internacional que prevê que a sua eficácia depende, inicialmente, da ratificação de um número determinado de Estados e depende igualmente a manutenção de sua aplicação desse mesmo número mínimo. Alcançado esse número, passa ele a ser aplicado, no direito internacional e nos diversos Estados a ele vinculados, até que um desses Estados resolve denunciá-lo. Dispõe o artigo 55 da Convenção de Viena que, sobre a redução das partes num tratado multilateral aquém do número necessário para a sua entrada em vigor, “a não ser que o tratado disponha diversamente, um tratado multilateral não se extingue pelo simples fato de que o número de partes ficou aquém do número necessário para sua entrada em vigor”.

Para o direito internacional, o tratado internacional de direitos humanos passa a ter existência com a sua assinatura, mas a sua eficácia fica dependente, em regra, de alguns fatores previstos em seu próprio texto, como um número mínimo de assinaturas ou algum lapso temporal. Cumpridas essas condições, passa o tratado internacional a ter eficácia no direito internacional.

O mais importante, porém, é assinalar, nesse ponto, que da maneira como apresentado o procedimento de existência, validade e eficácia dos tratados internacionais de direitos humanos não há possibilidade de um tratado vincular a República Federativa do Brasil no âmbito do direito internacional sem ter esse tratado aplicabilidade no âmbito do direito interno nacional. 
No momento em que o Presidente da República ratifica ou adere a determinado tratado internacional de direitos humanos, o início de sua aplicabilidade interna é simultânea a esses atos de vinculação internacional, a não ser que o próprio tratado, como visto, traga consigo condições ou termos suspensivos de eficácia. Não há como o Estado brasileiro vincular-se internacionalmente sem ter tomado todas as providências internas para que esse tratado, simultaneamente, vincule-o internamente. Caso o tratado internacional já se encontre perfeito, será ele aplicado internamente assim que o Presidente da República finalize o procedimento de sua celebração, seja pela ratificação, seja pela adesão; caso o tratado internacional ainda dependa de mais alguma condição, como alcançar um número mínimo de ratificações, aguarda-se esse momento para a sua integral aplicação.

4.5. Denúncia dos tratados internacionais de direitos humanos pela República Federativa do Brasil.

Denúncia é uma das diversas formas de extinção de um tratado internacional. É ato unilateral por meio do qual o Estado comunica a outra a outras partes que pretende dele desobrigar-se. Em regra, somente pode haver denúncia de um tratado internacional quando ela é expressamente permitida em seu texto.

Dispõe o artigo 56 da Convenção de Viena:

Artigo 56 - Denúncia ou retirada de um tratado que não contém disposições sobre extinção, denúncia ou retirada.

1. Um tratado que não contém disposição relativa a sua extinção, e que não prevê denúncia ou retirada, não é suscetível de denúncia ou retirada, a não ser que:

a) se estabeleça terem as partes tencionado admitir a possibilidade da denúncia ou retirada; ou

b) um direito de denúncia ou retirada possa ser deduzido da natureza do tratado.

2. Uma parte deverá notificar, com pelo menos doze meses de antecedência, a sua intenção de denunciar ou se retirar de um tratado, nos termos do parágrafo 1. 
A denúncia é, assim, uma das maneiras pelas quais o Estado pode desvincular-se de um tratado internacional. O tratado denunciado deixa de fazer parte da ordem jurídica interna estatal e deixa de vincular, por conseqüência, os indivíduos. Trata-se de ato de grande importância, assim como a ratificação e a adesão, pois todas inovam o ordenamento jurídico interno: a ratificação e a adesão acrescentam e a denúncia subtrai normas jurídicas da ordem interna.

Por igualmente inovar o ordenamento jurídico interno, deve a denúncia de um tratado internacional, necessariamente, passar pela aprovação do Poder Legislativo. É essa uma exigência do Estado Democrático de Direito. Permitir que um tratado internacional seja denunciado sem a participação do Legislativo ou da própria população, por meio de um dos instrumentos da democracia participativa, é acolher uma “perspectiva 'administrativista' de tratamento da inserção do Estado na comunidade internacional”313.

Para Maria Garcia, “a reiterada atitude do Poder Executivo de dispensar a manifestação do Legislativo na denúncia de tratado representa intolerável ato unilateral atentador do princípio da separação dos Poderes naquilo que envolve a vinculação dos Poderes que unitária e não isoladamente representam o Estado, a sociedade, o cidadão, mas, sobretudo, inconciliável com a declaração constitucional do Estado Democrático de Direito"314.

Thomas da Rosa de Bustamante argumenta que a resposta à questão encontra-se no artigo 49, I, da Constituição, que determina que "é da competência exclusiva do Congresso Nacional resolver definitivamente sobre tratados, acordos ou atos internacionais que acarretem encargos ou compromissos gravosos ao patrimônio nacional”.

Para Bustamante, o dispositivo constitucional dispõe que o Congresso Nacional é que resolverá sobre a celebração de tratados internacionais e "a expressão 'resolverá' é entendida aqui num sentido forte, abarcando a decisão final tanto acerca da celebração quanto da extinção dos tratados; resolver significa dar a última palavra, decidir com contornos de definitividade, e não meramente opinar. Assim, a afirmação de que o Presidente da República pode, por autoridade própria, extinguir um tratado internacional é insustentável à luz da distribuição de competência realizada pela Constituição Federal, eis que o tratado internacional é fonte formal de produção

\footnotetext{
${ }^{313}$ Cf. Pedro Bohomoletz de Abreu Dallari, Constituição e relações exteriores, p.13.

${ }^{314}$ Tratados internacionais, p.97.
} 
normativa, veículo para criação de regras gerais de comportamento obrigatórias para todos os indivíduos e pessoas jurídicas que se submetem ao imperium do Estado (brasileiro, in casu). A função legislativa é típica do Poder Legislativo, e não do Executivo. Se, no caso particular, o poder de celebrar tratados ('treaty-making power') é compartilhado entre o Chefe do Poder Executivo e o Congresso Nacional (tratando-se de uma exceção à regra geral de que a função do Legislativo é criar normas gerais e a do Executivo é aplicá-las de ofício), isso não pode significar que o Presidente da República possa arbitrariamente denunciar um compromisso internacional assumido pelo Brasil, pois uma exceção à regra geral de divisão dos Poderes (art. $2^{\circ}$ da Constituição da República) deve ser interpretada restritivamente”315.

Contudo, somente poderá ser votada pelo Legislativo denúncia de tratado internacional de direitos humanos aprovado pelo procedimento do artigo $5^{\circ}$, $\S 3^{\circ}$, da Constituição cujo conteúdo não viole o princípios do respeito aos direitos e garantias fundamentais, pois, se assim for, por força do artigo $60, \S 4^{\circ}$, IV, do texto constitucional, mesmo a deliberação de sua denúncia é vedada. Permite-se, assim, a modificação do sistema constitucional de direitos e garantias fundamentais, em modificações pontuais, desde que não haja violação ao citado princípio de respeito a esses direitos e garantias.

Deve-se observar, nessa linha argumentativa, que merecem proteção constitucional todos os direitos e garantias fundamentais constitucionais, e não somente os previstos no artigo $5^{\circ}$ da Constituição de 1988. Afirma Ana Cristina Costa Meireles que "os direitos sociais oriundos de tratados e convenções internacionais e incorporados ao nosso ordenamento jurídico passam a gozar de status de direitos fundamentais, e, por isso, não podem ser objeto de nova emenda constitucional, reduzindo-lhes ou retirandolhes as garantias que incorporam”316. O que se sustenta com relação aos direitos sociais, obviamente, aplica-se aos direitos fundamentais, em todas as suas gerações ou dimensões.

Nesse ponto, faz-se necessário registrar o entendimento de Elival da Silva Ramos, para quem “a interpretação sistemático teleológica do $\S 4^{\circ}$ do art. 60 da Constituição Federal não pode resultar no enrijecimento absoluto de amplos segmentos normativos do Texto Magno, razão pela qual sempre entendemos que a proteção especial que o Constituinte ali conferiu é abrangente única e tão-somente de princípios

\footnotetext{
${ }^{315}$ A impossibilidade de denúncia, p.344-345.

${ }^{316} \mathrm{O} \& 3^{\circ}$ do art. $5^{\circ}$, p.21.
} 
constitucionais, essenciais ao sistema democrático, que tão zelosamente buscou edificar. Por conseguinte, em se cuidando de proteção contra agressões diretamente dirigidas a esses postulados básicos, é vedada a eliminação do princípio federativo, do princípio do voto direto, secreto, universal e periódico, do princípio da separação dos Poderes e do princípio do respeito aos direitos e garantias fundamentais”317.

Por fim, resta analisar sucintamente os efeitos de eventual denúncia de tratado internacional de direitos humanos aprovado pelo procedimento previsto pelo artigo $5^{\circ}$, $\S 3^{\circ}$, da Constituição.

Como visto anteriormente, o tratado internacional ao ser incorporado ao direito interno não revoga o direito anterior a ele contrário, por terem direito interno e tratado internacional fundamentos de validade distintos. O tratado internacional incorporado suspende a eficácia do direito interno a ele contrário, desde que mais benéfico que o direito interno, e, com a sua denúncia, em princípio, retomaria o direito interno a sua aplicabilidade.

Assim, em princípio, com a denúncia de tratado internacional de direitos humanos, retomaria o direito interno a sua eficácia. No entanto, essa hipótese não é possível de se verificar com relação aos tratados internacionais de direitos humanos aprovados pelo procedimento do artigo $5^{\circ}, \S 3^{\circ}$, da Constituição, que tragam em seu texto normas menos benéficas que as previstas no texto constitucional anterior a sua incorporação, pois esses tratados, como visto, não têm o condão de afastar a eficácia da Constituição.

${ }^{317}$ A proteção aos direitos, p.226. 


\section{PosiçÃo hiERÁRQuica dos TRATAdos INTERNACIONAIS DE} DIREITOS HUMANOS NO PLANO DAS FONTES NORMATIVAS.

Por fim, apresentados os procedimentos de celebração e de incorporação dos tratados internacionais de direitos humanos pela ordem jurídica brasileira, passa-se ao estudo da posição hierárquica ocupada por esses tratados no plano das fontes normativas.

Como se percebe, este é o desfecho prático, necessário e logicamente retirado de todos os pressupostos apresentados ao longo do trabalho.

Incorporado o tratado internacional de direitos humanos deve ele ocupar, necessariamente, um espaço na ordem jurídica interna brasileira. E conseqüência dessa sua posição hierárquica, como já afirmado anteriormente, é o seu relacionamento com os demais atos normativos da ordem jurídica nacional, sejam eles constitucionais ou infraconstitucionais.

Como afirmado anteriormente, o ponto central do artigo $5^{\circ}$, $\S 3^{\circ}$, da Constituição é a expressão “serão equivalentes às emendas constitucionais”, conseqüência atribuída aos tratados de direitos humanos aprovados conforme o procedimento previsto nesse mesmo dispositivo.

Sabe-se que essa alteração constitucional, operada pela emenda constitucional $n^{\circ}$ 45/04, teve como propósito principal responder à discussão doutrinária e jurisprudencial que se travava sobre a posição hierárquica dos tratados internacionais de direitos humanos. Vale apresentar sucintamente o quadro da discussão ${ }^{318}$.

Parte da doutrina, acolhida pelo Supremo Tribunal Federal ${ }^{319}$, afirmava que os tratados internacionais, inclusive os de direitos humanos, eram incorporados com posição hierárquica infraconstitucional. Essa corrente, como afirmamos em outro trabalho $^{320}$, parte da constatação de que ao direito interno de cada Estado compete determinar a posição hierárquica dos tratados internacionais incorporados, inclusive os de direitos humanos.

\footnotetext{
${ }^{318}$ Para uma análise mais detida, cf. Marco Antonio Corrêa Monteiro, O impacto.

${ }^{319}$ Entendimento firmado no RE ${ }^{\circ}{ }^{80.004 / 77, ~ R T J ~ 33 / 809 . ~ A c e r c a ~ d e s s a ~ d e c i s a ̃ o ~ d o ~ S u p r e m o ~ T r i b u n a l ~}$ Federal, para uma análise da matéria nela tratada, cf. Gastão de Moura Maia Filho, Os títulos de crédito, Fábio Konder Comparato, Vigência das Convenções de Genebra, Rubens Requião, Cambial; para uma descrição dos votos dos Ministros, cf. Jacob Dolinger, Direito internacional privado, p.102-105; para uma análise crítica de seu conteúdo, cf. José Carlos de Magalhães, O Supremo Tribunal Federal e as relações, Luiz Olavo Baptista, Chronique, p.603-604.

${ }^{320}$ Cf. Marco Antonio Corrêa Monteiro, O impacto, p.22.
} 
Nesse sentido, afirma Fernanda Dias Menezes de Almeida que, “incorporado ao ordenamento jurídico, a questão que se põe a seguir é a de saber que posição o tratado ocupará neste ordenamento. Estará ele no mesmo nível das leis ordinárias? Ou terá o status de norma constitucional? Ou quem sabe ficará situado acima da própria Constituição?” E segue a constitucionalista afirmando que “a resposta a esta questão tem variado, conforme o Estado. Cabe a este, mais uma vez no exercício de sua soberania, estabelecer a posição do tratado incorporado na hierarquia das normas jurídicas internas”321.

Assim é que a Constituição da República, em seu artigo 102, III, b, prescreve que “compete ao Supremo Tribunal Federal, precipuamente, a guarda da Constituição, cabendo-lhe julgar, mediante recurso extraordinário, as causas decididas em única ou última instância, quando a decisão recorrida declarar a inconstitucionalidade de tratado ou lei federal”, possibilitando-se a ilação de que, se um tratado internacional pode ser declarado inconstitucional pelo Supremo, sua posição hierárquica é infraconstitucional.

Sobre o dispositivo, afirma José Francisco Rezek que, “embora sem emprego de linguagem direta, a Constituição brasileira deixa claro que os tratados se encontram aqui sujeitos ao controle de constitucionalidade, a exemplo dos demais componentes infraconstitucionais do ordenamento jurídico" ${ }^{322}$.

Agrega-se a esse argumento o fato de os tratados internacionais de direitos humanos, à época, serem incorporados, após aprovação de decreto legislativo pelo Poder Legislativo, com procedimento equivalente ao das leis ordinárias. Sobre a questão, sustenta Pedro Bohomoletz de Abreu Dallari que, “aparentemente, a equiparação de tratado internacional a lei interna, com todos os efeitos decorrentes, encontra um de seus elementos de sustentação nas normas de processo legislativo aplicáveis para a aprovação desta e daquele, que estabelecem, igualmente para ambos, a subordinação, a princípio, à regra geral fixadora da exigência de quórum de maioria simples, estatuída no art. 47 da Constituição: 'Salvo disposição constitucional em contrário, as deliberações de cada Casa e de suas Comissões serão tomadas por maioria dos votos, presente a maioria absoluta dos membros',323.

Por outro lado, procurava-se atribuir aos tratados internacionais de direitos humanos posição hierárquica constitucional com fundamento, principalmente, no artigo

\footnotetext{
${ }^{321}$ A incorporação, p.51.

${ }^{322}$ Direito internacional público, p.97.

${ }^{323}$ Constituição e tratados internacionais, p.111-112.
} 
$5^{\circ}$, § $2^{\circ}$, da Constituição ${ }^{324}$. Para Maria Paula Alves de Souza, “a redação do $\S 2^{\circ}$ do art. $5^{\circ}$ da Constituição Federal fomentou intensas reflexões e debates doutrinários. Da leitura pura e simples conclui-se que a Constituição brasileira ao enumerar os direitos fundamentais não pretendeu ser exaustiva, porém, uma parte da doutrina foi mais além e vislumbrou que tal disposição implicaria na autorização da própria Constituição para que os direitos e garantias provenientes dos tratados internacionais se incluam no nosso ordenamento jurídico interno como se normas constitucionais fossem»325.

Cabe transcrever trecho de texto de Flávia Piovesan, que, apesar de longo, sintetiza bem os argumentos dessa corrente:

A Carta de 1988 consagra de forma inédita, ao fim da extensa Declaração de Direitos por ela prevista, que os direitos e garantias expressos na Constituição 'não excluem outros decorrentes do regime e dos princípios por ela adotados, ou dos tratados internacionais em que a República Federativa do Brasil seja parte' (art. $5^{\circ}$, parágrafo $2^{\circ}$ ).

Note-se que a Constituição de 1967, no art. 153, parágrafo 36, previa: 'A especificação dos direitos e garantias expressos nesta Constituição não exclui outros direitos e garantias decorrentes do regime e dos princípios que ela adota'. A Carta de 1988 inova, assim, ao incluir, dentre os direitos constitucionalmente protegidos, os direitos enunciados nos tratados internacionais de que o Brasil seja signatário.

Ora, ao prescrever que 'os direitos e garantias expressos na Constituição não excluem outros direitos decorrentes dos tratados internacionais', a contrario sensu, a Carta de 1988 está a incluir, no catálogo de direitos constitucionalmente protegidos, os direitos enunciados nos tratados internacionais em que o Brasil seja parte. Este processo de inclusão implica na incorporação pelo texto constitucional destes direitos.

\footnotetext{
${ }^{324}$ Havia, igualmente, entendimento pela posição hierárquica supra-constitucional (cf. Celso D. de Albuquerque Mello, Curso, p.792) e pela posição hierárquica infraconstitucional, porém supra-legal (cf. Vicente Marotta Rangel, La procédure, p.264-265); contudo, são os posicionamentos pela posição hierárquica constitucional e pela posição infraconstitucional ordinária os que disputaram mais intensamente a prevalência, na doutrina e na jurisprudência.

${ }^{325}$ Integração dos tratados, p.25.
} 
Ao efetuar tal incorporação, a Carta está a atribuir aos direitos internacionais uma hierarquia especial e diferenciada, qual seja, a hierarquia de norma constitucional. Os direitos enunciados nos tratados de direitos humanos de que o Brasil é parte integram, portanto, o elenco dos direitos constitucionalmente consagrados. Esta conclusão advém ainda de interpretação sistemática e teleológica do texto, especialmente em face da força expansiva dos valores da dignidade humana e dos direitos fundamentais, como parâmetros axiológicos a orientar a compreensão do fenômeno constitucional $^{326}$.

Em síntese, era esse o panorama anterior à promulgação da emenda constitucional $n^{0}$ 45/04. Com a inserção do $\S 3^{\circ}$ no artigo $5^{\circ}$ da Constituição, a divergência doutrinária não cessou, pois, em regra, os que sustentavam a posição hierárquica constitucional dos tratados internacionais de direitos humanos incorporados até aquele momento mantiveram o seu entendimento, da mesma maneira que os defensores de sua posição hierárquica infraconstitucional não se convenceram do contrário $^{327}$.

5.1. Equivalência dos tratados internacionais de direitos humanos às emendas constitucionais (artigo $5^{\circ}$, § $3^{\circ}$, da Constituição).

Em que pese o entendimento pela posição hierárquica constitucional dos tratados internacionais de direitos humanos incorporados anteriormente à emenda constitucional $n^{\circ} 45 / 04$, somente com a inserção do $\S 3^{\circ}$ ao artigo $5^{\circ}$ do texto constitucional passou a ser possível atribuir posição hierárquica constitucional aos tratados internacionais de direitos humanos, desde que aprovados pelo procedimento nele previsto.

Manoel Gonçalves Ferreira Filho, nesse sentido, afirma que "a Emenda n. 45/2004 veio a esclarecer a situação dos direitos advenientes de tratados. Decorre dela

\footnotetext{
${ }^{326}$ Direitos humanos, p.75-76. Também nesse sentido, cf. Valério de Oliveira Mazzuoli, A influência dos tratados internacionais, p.90-93.

${ }^{327}$ Para uma análise mais detalhada, cf. Marco Antonio Corrêa Monteiro, O impacto; nesse trabalho ressaltamos a opinião de José Afonso da Silva, Comentário contextual, p.179, que reconheceu superado seu entendimento anterior, pela posição hierárquica constitucional dos tratados internacionais de direitos humanos, exceção que confirma a regra.
} 
deverem-se distinguir duas situações. Uma, a dos tratados que, de acordo com o novo $\S$ $3^{\circ}$ do art. $5^{\circ}$ (parágrafo acrescentado por essa Emenda), tiverem sido aprovados pelas Casas do Congresso Nacional, em dois turnos, por três quintos dos votos de seus respectivos membros (procedimento equivalente ao de adoção de Emenda Constitucional - v. art. 60, $\S 2^{\circ}$, da Lei Magna); outra, a dos tratados que não foram assim aprovados. No primeiro caso, os direitos decorrentes do tratado têm status constitucional, equiparam-se aos direitos fundamentais enunciados pela Constituição (arts. $5^{\circ}, 6^{\circ}$ etc.). Claro está que ato que contrariar tais direitos, incidirá em inconstitucionalidade. No segundo, o status é [de] lei infraconstitucional”328.

Pedro de Abreu Dallari, nesse diapasão, afirma que, “com o novo $\S 3^{\circ}$ do art. $5^{\circ}$, estabelece-se, de forma inequívoca, conforme preceituado de forma literal, a possibilidade de que tratados em matéria de direitos humanos tenham equivalência com emenda constitucional, podendo acarretar, portanto, a agregação de novas normas ao sistema da Constituição ou mesmo a derrogação de normas que nele figurem. Mas isto desde que, quando da apreciação do tratado pelo Congresso Nacional, haja aprovação na Câmara dos Deputados e no Senado Federal, em dois turnos em cada uma das Casas, e por pelo menos três quintos dos votos dos membros respectivos. Acolheu-se, assim, a tese de que tratados sobre direitos humanos, dada a relevância da matéria, devem merecer acolhida diferenciada no direito brasileiro, mas procurou-se igualmente contemplar, por meio do quórum previsto para essa excepcionalidade, a lógica do processo legislativo, que exige maior endosso político à aprovação de normas jurídicas de maior posição hierárquica”329.

Cláudio Lembo, sobre o tema, afirma que “a Emenda Constitucional n. 45/2004 explicitou que, quando aprovado por quorum de três quintos dos votos dos membros das duas Casas do Congresso - Senado e Câmara Federal -, em dois turnos, o tratado internacional será equivalente à emenda constitucional (§ $3^{\circ}$ do art. $5^{\circ}$ ),330.

Nessa mesma linha, Monica Herman Caggiano aduz que "depreende-se que o constituinte outorgou um tratamento muito exato, específico e restrito à questão. Conferiu o pedestal constitucional tão só aqueles tratados e convenções que cuidassem de direitos humanos e que atendessem às regras de aprovação legislativa estabelecidas para as emendas constitucionais. Em se afigurando excepcional o dispositivo, restrito o

\footnotetext{
${ }^{328}$ Direitos humanos, p.101.

${ }^{329}$ Tratados internacionais, p.89.

${ }^{330}$ A pessoa, p.228.
} 
seu campo interpretativo, porquanto ausente a flexibilidade necessária a exercícios de hermenêutica" ${ }^{331}$.

Nesse mesmo sentido, Oscar Vilhena Vieira sustenta que "no caso do $\S 3^{\circ}$ a Constituição determina a equiparação a direitos fundamentais aqueles direitos decorrentes de tratados dos quais o Brasil seja parte, desde que aprovados por quórum de três quintos dos membros do Congresso Nacional - ou seja, o mesmo quórum exigido para as emendas à Constituição. Essa questão não parece oferecer tantas dúvidas a partir da reforma constitucional imposta pela Emenda 45/2004”332.

Em seus comentários sobre a reforma do Judiciário, Sérgio Rabello Tamm Renault e Pierpaolo Bottini, após analisarem a possibilidade do que a doutrina rotulou de "federalização dos crimes contra os direitos humanos", afirmam que, "no mesmo sentido de valorizar e conferir funcionalidade ao sistema de proteção aos direitos humanos, a emenda cria processo legislativo diferenciado, ainda que facultativo, para a inserção de tratados e acordos internacionais que versem sobre direitos humanos no ordenamento jurídico. A nova redação do $\S 3^{\circ}$ do art. $5^{\circ}$ permite que o Congresso Nacional aprove os tratados e acordos mencionados pelo quorum qualificado de três quintos, em dois turnos, em processo similar ao conferido para a criação de emenda constitucional. Nestes casos, as regras internacionais não mais ostentariam o status de lei ordinária, como ocorria anteriormente, mas a condição de normas constitucionais, e gozariam de supremacia sobre as demais normas do ordenamento jurídico, fortalecendo o sistema de proteção de direitos humanos e dotando de maior rigidez os preceitos que tratam do tema"333.

Dessa forma, somente os tratados internacionais de direitos humanos aprovados pelo procedimento previsto no artigo $5^{\circ}, \S 3^{\circ}$, da Constituição serão equivalentes às

${ }^{331}$ Emenda constitucional n. 45/2004, p.187.

${ }^{332}$ Direitos fundamentais, p.42.

${ }^{333}$ Primeiro passo, p.10-11. Nesse sentido, entre outros, Carmen Tiburcio, A EC n. 45, p.126, Hidemberg Alves da Frota, Os tratados de proteção, p.6, Carolina Ormanes Massoud, Hierarquia das normas, p.910, Ana Cristina Costa Meireles, $O \S 3^{\circ}$ do art. $5^{\circ}$, p.28. Parece ser este também o posicionamento de José Carlos Francisco, Bloco de constitucionalidade, p.102-103, ao admitir "sustentável” a argumentação daqueles que atribuem posição hierárquica constitucional tão somente aos tratados de direitos humanos que forem aprovados após a inserção do $\S 3^{\circ}$ ao art. $5^{\circ}$, observado o procedimento nele previsto, o que se confirma, aparentemente, com a tese ventilada da "recepção" dos tratados de direitos humanos anteriores para que adquiram posição hierárquica constitucional. Pela necessidade de obediência do procedimento previsto no artigo $5^{\circ}, \S 3^{\circ}$, da Constituição para os tratados posteriores, mas a atribuição de posição hierárquica constitucional aos tratados anteriores, por força do artigo $5^{\circ}$, § $2^{\circ}$, cf. Amélia Regina Mussi Gabriel, Hierarquia jurídica, p.261-263. Pela inconstitucionalidade do artigo $5^{\circ}$, § $3^{\circ}$, da Constituição, cf. Jorge Luiz Ieski Calmon de Passos, Direitos humanos, p.353, tomando como parâmetro os parágrafos $1^{\circ} \mathrm{e}$ $2^{\circ}$ do artigo $5^{\circ}$, Luiz Alexandre Cruz Ferreira e Maria Cristina Blanco Tárrega, Reforma do Poder Judiciário, p.456-457, tomando como parâmetro o Pacto de São José da Costa Rica, que teria posição hierárquica constitucional, por força do artigo $5^{\circ}, \S 2^{\circ}$, da Constituição. 
emendas constitucionais. Isso importa em dizer que os tratados internacionais aprovados anteriormente à emenda constitucional no 45/2004 não são equivalentes às emendas, assim como igualmente não são equivalentes às emendas os tratados incorporados posteriormente, mas sem obediência ao procedimento previsto no dispositivo constitucional.

Nesse sentido já se manifestou, ainda que incidentalmente, o Supremo Tribunal Federal, em voto do Ministro Carlos Mário Velloso. Decidiu o Ministro em seu voto que não existe no ordenamento jurídico brasileiro a garantia do duplo grau de jurisdição e, ao analisar o disposto no artigo $8^{\circ}, 2$, h, da Convenção Americana de Direitos Humanos, que consagrou, ao menos no âmbito do direito processual penal, essa garantia, afirmou que, no direito brasileiro, prevalece a Constituição sobre quaisquer tratados internacionais, inclusive os de proteção aos direitos humanos, o que impede, em princípio, a aplicação do Pacto de São José. Para Velloso, “verifica-se, assim, a prevalência da Constituição Federal em relação aos tratados e convenções internacionais não aprovados segundo o procedimento descrito no $\S 3^{\circ}$ do art. $5^{\circ}$ da $\mathrm{CF} / 88^{\text {, } 334}$.

Determinados os tratados que podem ser equivalentes às emendas constitucionais, resta, por fim, apontar o sentido dessa expressão: “equivalentes às emendas constitucionais”. No que diz respeito ao procedimento de incorporação desses tratados, já se tratou anteriormente; pretende-se agora especificar suas decorrências no que tange a sua posição hierárquica.

Não há dúvidas de que um tratado equivalente às emendas constitucionais goza de supremacia constitucional, o que quer dizer que ato normativo infraconstitucional a ele contrário será inconstitucional, tendo como conseqüência, todavia, não a invalidade do ato inconstitucional, mas tão-somente a suspensão de sua eficácia.

Contudo, da mesma maneira que a emenda constitucional, pode o tratado internacional ser objeto de controle de constitucionalidade com relação ao texto constitucional anterior a sua incorporação (devendo respeitar, inclusive, ao disposto no

\footnotetext{
${ }^{334}$ Cf. Agravo regimental no agravo de instrumento no 513.044-5-SP. Parece ser essa a tendência nos Tribunais, ainda que possa ser apontada divergência nos julgados já existentes, como demonstra Maria Paula Alves de Souza, integração dos tratados, p.73-82, em especial no Superior Tribunal de Justiça; dissenso jurisprudencial que acompanha o dissenso doutrinário apontado em outro trabalho (cf. Marco Antonio Corrêa Monteiro, O impacto). Registre-se, contudo, que a questão ainda não foi discutida amplamente no Supremo Tribunal Federal, verdadeiro intérprete da Constituição da República.
} 
artigo 60 da Constituição de $1988^{335}$ ), tornando-se parâmetro de controle com relação aos tratados internacionais equivalentes às emendas constitucionais e às próprias emendas constitucionais posteriores.

\subsection{Alcance do $\S 2^{\circ}$ do artigo $5^{\circ}$ da Constituição.}

Dispõe o artigo $5^{\circ}$, § $2^{\circ}$, da Constituição que “os direitos e garantias expressos nesta Constituição não excluem outros decorrentes do regime e dos princípios por ela adotados, ou dos tratados internacionais em que a República Federativa do Brasil seja parte”.

Como visto anteriormente, parte da doutrina nacional procurava atribuir posição hierárquica constitucional aos tratados internacionais de direitos humanos com fundamento nesse dispositivo constitucional. Esse, porém, não é o sentido mais apropriado que se lhe deve atribuir. O dispositivo constitucional, não se pode negar, prescreve natureza constitucional a direitos e garantias fundamentais previstos fora do texto da Constituição, “mas isto, por si só, não autoriza a conclusão a que chegaram os que advogam hoje hierarquia privilegiada para os tratados de direitos humanos no Brasil. Sim, porque o certo é que nem toda matéria de natureza constitucional se esgota na Constituição formal. Assim sendo, é perfeitamente possível encontrar-se matéria dessa natureza disciplinada na legislação complementar ou ordinária, que se edite para integrar a eficácia da Constituição. E nem por isso essa legislação terá o status de normas constitucionais, integrando um 'bloco de constitucionalidade', sem que a Constituição expressamente disponha nesse sentido”336.

Nas palavras de Fernanda Dias Menezes de Almeida, “o que de concreto se extrai do artigo $5^{\circ}, \S 2^{\circ}$, é que o catálogo de direitos da Constituição não constitui numerus clausus, ou, por outra, que não prevalece, na espécie, o brocardo inclusio unius exclusio alterius" ${ }^{337}$.

\footnotetext{
${ }^{335}$ Segundo Alexandre de Moraes, Curso, p.729-730, “na hipótese do $\S 3^{\circ}$, do art. $5^{\circ}$, pelo qual a EC $n^{\circ}$ 45/04 estabeleceu que os tratados e convenções internacionais sobre direitos humanos que forem aprovados, em cada Casa do Congresso Nacional, em dois turnos, por três quintos dos votos dos respectivos mombros, serão equivalentes às emendas constitucionais, plenamente possível ao Supremo Tribunal Federal a análise da constitucionalidade ou não do texto incorporado com status constitucional, desde que se verifique o respeito aos parâmetros fixados no art. 60 da Constituição para a alteração do texto constitucional”.

${ }^{336}$ Cf. Fernanda Dias Menezes de Almeida, A incorporação dos tratados, p.54; cf. também José Levi Mello do Amaral Júnior, Os tratados, p.198.

${ }^{337}$ A incorporação dos tratados, p.54.
} 
Nesse mesmo sentido, aduz Dalmo de Abreu Dallari que “pelo $\S 2^{\circ}$ do art. $5^{\circ}$ ficou estabelecido que os direitos e garantias expressos na Constituição não excluem outros decorrentes do regime e dos princípios constitucionais, ou ainda de tratados internacionais de que o Brasil seja parte. Com base nessa regra poderá ser sustentada a existência de direitos implícitos, desde que não sejam contrários a alguma disposição constitucional”338.

Leonardo Avelino Duarte igualmente sustenta que, "com o emprego de uma análise sistemática da Constituição, conclui-se que o preceptivo normativo supracitado não é outro senão o de dar mensagem ao intérprete e aplicador do direito de que o rol de Direitos constantes no art. $5^{\circ}$ não é exaustivo, tão-somente. Assim, existem outros Direitos e garantias que integram a ordem positiva brasileira, além daqueles dispostos explícita ou implicitamente na Constituição Federal. Mas o parágrafo não confere, ressalte-se mais uma vez, qualquer prevalência àqueles Direitos”339.

Deve ser esse o sentido atribuído ao artigo $5^{\circ}$, $\S 2^{\circ}$, da Constituição, e não o de atribuição de posição hierárquica constitucional a tratados internacionais de direitos humanos.

5.3. Posição hierárquica dos tratados internacionais de direitos humanos incorporados antes da emenda constitucional $n^{\circ}$ 45/04.

Excluída a possibilidade de atribuição de posição hierárquica constitucional aos tratados internacionais de direitos humanos incorporados antes da Emenda Constitucional $n^{\circ} 45 / 04$ com fundamento no artigo $5^{\circ}$, $\S \S 2^{\circ}$ e $3^{\circ}$, da Constituição, resta a esses tratados internacionais posição hierárquica infraconstitucional, tal como vinha decidindo o Supremo Tribunal Federal ${ }^{340}$.

Nesse sentido, afirma Pedro de Abreu Dallari que “a nova exigência de maior quórum na aprovação legislativa acaba aparentemente por endossar a interpretação de que as disposições do $\S 2^{\circ}$ do art. $5^{\circ}$, vigentes desde a promulgação da Constituição, em

\footnotetext{
${ }^{338}$ Os direitos fundamentais, p.433.

${ }^{339}$ Estudos sobre a posição, p.84.

${ }^{340}$ Entre outras, na ADI 1.480 MC/DF, relator Ministro Celso de Mello, de 4 de setembro de 1997, em cuja emenda está disposto o seguinte: "PARIDADE NORMATIVA ENTRE ATOS INTERNACIONAIS E NORMAS INFRACONSTITUCIONAIS DE DIREITO INTERNO. Os tratados ou convenções internacionais, uma vez regularmente incorporados ao direito interno, situam-se, no sistema jurídico brasileiro, nos mesmos planos de validade, de eficácia e de autoridade em que se posicionam as leis ordinárias, havendo, em conseqüência, entre estas e os atos de direito internacional público, mera relação de paridade normativa”.
} 
1988, não teriam o condão, por si sós, de gerar para os tratados nessa matéria os efeitos de norma da Constituição. Tal condição só ocorreria daqui por diante e desde que atendidas as exigências do novo $\S 3^{\circ}$ do art. $5^{\circ}{ }^{341}$. Ainda nesse sentido, afirmam Gilmar Ferreira Mendes, Inocêncio Mártires Coelho e Paulo Gustavo Gonet Branco que “os tratados aprovados antes da Emenda continuam a valer como normas infraconstitucionais"342.

José Carlos Francisco, contudo, procurou apresentar reposta distinta. Sobre a questão, admite o autor que “é sustentável a argumentação daqueles que negam a recepção desses atos anteriores à Emenda Constitucional 45, pois o mencionado $\S 3^{\circ}$ do art. $5^{\circ}$ prevê que serão equivalentes às emendas constitucionais os tratados e convenções internacionais sobre direitos humanos 'que forem aprovados, em cada Casa do Congresso Nacional, em dois turnos, por três quintos dos votos dos respectivos membros', motivo pelo qual os atos normativos anteriores (aprovados nos moldes convencionais, por Decreto Legislativo, e promulgados e publicados por Decreto Presidencial) permaneceriam com estatura de lei ordinária. Todavia, com o devido respeito aos entendimentos em sentido diverso, receio que essa não seja a melhor conclusão (ainda que ela venha a prevalecer), em razão do princípio da máxima efetividade, pela lógica da recepção constitucional e até mesmo pela interpretação sistemática da Emenda Constitucional 45”343.

Francisco Rezek responde ao problema com fundamento na teoria da recepção constitucional. Leciona o internacionalista, ao tratar do disposto no artigo $5^{\circ}, \S 3^{\circ}$, da Constituição, que "uma última dúvida diz respeito do passado, a algum eventual direito que um dia se tenha descrito em tratado de que o Brasil seja parte - e que já não se encontre no rol do art. 5. Qual o seu nível? Isso há de gerar controvérsia entre os constitucionalistas, mas é sensato crer que ao promulgar esse parágrafo na Emenda constitucional 45, de 8 de dezembro de 2004, sem nenhuma ressalva abjuratória dos tratados sobre direitos humanos outrora concluídos mediante processo simples, o Congresso constituinte os elevou à categoria dos tratados de nível constitucional. Essa é uma equação jurídica da mesma natureza daquela que explica que o nosso Código Tributário, promulgado a seu tempo como lei ordinária, tenha-se promovido a lei

\footnotetext{
${ }^{341}$ Tratados internacionais, p.91.

${ }^{342}$ Curso, p.216-217.

${ }^{343}$ Bloco de constitucionalidade, p.103.
} 
complementar à Constituição desde o momento em que a carta disse que as normas gerais de direito tributário deveriam estar expressas em diploma dessa estatura”344.

Deve-se discutir, igualmente, a atribuição de posição hierárquica supralegal, ainda que infraconstitucional, ao tratados internacionais de direitos humanos incorporados anteriormente. Sustenta Oscar Vilhena Vieira, ao comentar o disposto no artigo $5^{\circ}, \S 2^{\circ}$, da Constituição, que "estes direitos decorrentes do regime e dos princípios adotados pela Constituição ou decorrentes dos tratados dos quais o Brasil seja parte (mas não aprovados por procedimentos de emenda à Constituição) têm, tal como no sistema Francês, hierarquia supralegal, porém, infraconstitucional. Colocando-se acima da insegurança e volatilidade do direito ordinário, mas devendo submeter-se à vontade constitucional”345.

Nesse mesmo sentido, afirmam Gilmar Ferreira Mendes, Inocêncio Mártires Coelho e Paulo Gustavo Gonet Branco que “é mais consistente a interpretação que atribui a característica de supralegalidade aos tratados e convenções de direitos humanos. Essa tese pugna pelo argumento de que os tratados sobre direitos humanos seriam infraconstitucionais, porém, diante de seu caráter especial em relação aos demais atos normativos internacionais, também seriam dotados de um atributo de supralegalidade״346. Já registrou esse seu entendimento o Ministro Gilmar Mendes em seu voto no recurso extraordinário n $n^{0}$ 466.343/SP, proferido em sessão do Plenário de $22 / 11 / 2006^{347}$.

Essa tese, contudo, não deve prevalecer, pois carece de fundamento normativo constitucional, tal qual ocorre no direito francês. Ademais, os tratados internacionais aprovados anteriormente à reforma de 2004 o foram em obediência ao mesmo procedimento de aprovação das leis ordinárias, o que, segundo Pedro Dallari, “não é um problema menor, eivado de excesso de formalismo, pois remete ao plano da aferição do respaldo social mínimo exigido para aprovação de cada tipo de norma jurídica - que, na democracia representativa, tem no quórum parlamentar o seu indicador mais utilizado"348.

Cabe, por fim, registrar que, mesmo após a introdução do artigo $5^{\circ}$, $\S 3^{\circ}$, da Constituição, há quem continue sustentando a posição hierárquica constitucional dos

\footnotetext{
${ }^{344}$ Direito internacional público, p.103.

${ }^{345}$ Direitos fundamentais, p.43.

${ }^{346}$ Curso, p.665.

${ }^{347}$ Cf. Informativos do STF $n^{\circ} 449$ e 450, entendimento igualmente expresso em seu voto no Habeas Corpus n ${ }^{\circ}$ 90.172-7-SP.

${ }^{348}$ Constituição e tratados internacionais, p.111-112.
} 
tratados internacionais de direitos humanos aprovados anteriormente, por força do $\S 2^{\circ}$ do mesmo dispositivo constitucional. Flávia Piovesan aduz que, “desde logo, há que se afastar o entendimento de que, em face do $\S 3^{\circ}$ do art. $5^{\circ}$, todos os tratados de direitos humanos já ratificados seriam recepcionados como lei federal, pois não teriam obtido o quorum qualificado de três quintos demandado pelo aludido parágrafo. Reitere-se que, por força do art. $5^{\circ}, \S 2^{\circ}$, todos os tratados de direitos humanos, independentemente do quorum de sua aprovação são materialmente constitucionais. O quorum qualificado está tão-somente a reforçar tal natureza constitucional, ao adicionar um lastro formalmente constitucional”349. Não há dúvidas de que direitos humanos previstos em tratados internacionais são materialmente constitucionais, independentemente até do disposto no artigo $5^{\circ}, \S 2^{\circ}$; isso não os faz, contudo, gozar de supremacia constitucional, com tudo o que disso decorre.

Somente, todavia, com o acréscimo do $\S 3^{\circ}$ ao artigo $5^{\circ}$ surge a possibilidade de tratados internacionais de direitos humanos gozarem de posição hierárquica constitucional, desde que aprovados em obediência ao procedimento nesse dispositivo previsto. Disso decorre que os tratados internacionais de direitos humanos anteriormente aprovados têm posição hierárquica infraconstitucional, podendo vir a gozar de hierarquia constitucional se, eventualmente, forem reapreciados nos termos do novo dispositivo ${ }^{350}$. Trata-se essa de outra função do $\S 3^{\circ}$ do artigo $5^{\circ}$ da Constituição. O dispositivo acrescentado pela emenda constitucional de 2004, além de introduzir novo procedimento de incorporação de tratados internacionais de direitos humanos, traz a possibilidade de atribuição de posição hierárquica constitucional a tratados internacionais de direitos humanos já incorporados, desde que sejam eles reapreciados pelo procedimento previsto no dispositivo constitucional.

5.4. A idéia de bloco de constitucionalidade no direito brasileiro e a organicidade da Constituição de 1988.

\footnotetext{
${ }^{349}$ Cf. Reforma do Judiciário, p.72. Já apontamos, em trabalho anterior, essa tendência na manutenção do entendimento tanto dos que sustentavam posição hierárquica constitucional quanto dos que sustentavam posição hierárquica infraconstitucional dos tratados internacionais de direitos humanos (cf. Marco Antonio Corrêa Monteiro, O impacto).

${ }^{350}$ Maria Paula Alves de Souza, Integração dos tratados, p.90, nota de rodapé 184, aponta quatro exemplos de tratados aos quais se pretende atribuir posição hierárquica constitucional pela reapreciação, nos termos do artigo $5^{\circ}$, $\S 3^{\circ}$, da Constituição; esse é o entendimento que deve prevalecer.
} 
Por fim, devem ser analisadas duas importantes decorrências da incorporação dos tratados internacionais de direitos humanos com posição hierárquica constitucional.

A primeira delas é que o texto do tratado internacional, em regra, não integrará o texto constitucional. A razão para tanto é bastante simples: a emenda constitucional, em regra, é aprovada justamente para modificar o texto constitucional, o que não acontece com os tratados internacionais. Mesmo entre as emendas constitucionais há dispositivos que não integram o texto constitucional, e nem por isso deixam de ter posição hierárquica constitucional.

Exemplo é a Emenda Constitucional $n^{0}$ 32/01. Em seu artigo $1^{\circ}$, fica determinado que “os arts. 48, 57, 61, 62, 64, 66, 84, 88 e 246 da Constituição Federal passam a vigorar com as seguintes alterações”, ao que se segue uma série de dispositivos a serem integrados ao texto constitucional; o artigo $2^{\circ}$, por sua vez, prescreve tão-somente que "as medidas provisórias editadas em data anterior à da publicação desta emenda continuam em vigor até que medida provisória ulterior as revogue explicitamente ou até deliberação definitiva do Congresso Nacional”, não determinando, portanto, integração ao texto constitucional.

Não se encontram em textos de tratados internacionais dispositivos similares ao do artigo $1^{\circ}$ da emenda constitucional $n^{\circ} 32 / 01$, mas, sim, ao de seu artigo $2^{\circ}$. Por essa razão os textos dos tratados internacionais de direitos humanos, em regra, não integram o texto constitucional, como é de costume nos casos de emenda à Constituição. Na hipótese remota de um tratado internacional de direitos humanos com posição hierárquica constitucional determinar que alguns artigos da Constituição passam a vigorar com as suas alterações, o seu texto poderá afastar a aplicação do texto constitucional, nos moldes que se expôs ao longo do trabalho.

Os tratados internacionais de direitos humanos, aprovados pelo procedimento previsto no artigo $5^{\circ}, \S 3^{\circ}$, da Constituição, têm, pois, posição hierárquica constitucional, ainda que não integrem o texto constitucional. Fazem parte, dessa forma, da Constituição formal da República Federativa do Brasil ${ }^{351}$ e, em razão de sua supremacia, são parâmetro para o controle de constitucionalidade. Compõem os tratados internacionais de direitos humanos, incorporados pelo procedimento do artigo $5^{\circ}, \S 3^{\circ}$,

${ }^{351}$ Cf. Elival da Silva Ramos, A inconstitucionalidade, p.50. Aponta Elival da Silva Ramos que se caracteriza a Constituição em sentido formal pela possibilidade de identificação de um conjunto de normas jurídicas cuja modificação depende do cumprimento de um procedimento especial, independentemente de seu conteúdo (norma formalmente constitucional em razão da rigidez constitucional). É o caso dos tratados internacionais de direitos humanos, incorporados pelo procedimento especial do artigo $5^{\circ}$, $\S 3^{\circ}$, da Constituição. 
da Constituição, ao lado do texto orgânico da Constituição e dos dispositivos não integrados a seu texto das emendas à Constituição, o que a doutrina denomina bloco de constitucionalidade.

A noção de bloco de constitucionalidade é fruto de construção jurisprudencial do Conselho constitucional francês. No direito gaulês, o parâmetro de controle de constitucionalidade não se resume ao documento constitucional de 1958. Compõem o bloco de constitucionalidade, ao lado da Constituição de 1958, o preâmbulo da Constituição de 1946, a Declaração dos Direitos do Homem e do Cidadão de 1789 e os princípios fundamentais reconhecidos pelas leis da República ${ }^{352}$.

Não foi com a emenda constitucional $n^{\circ}$ 45/04 que surgiu, no direito brasileiro, um bloco de constitucionalidade. Existe um bloco de constitucionalidade na ordem jurídica brasileira, ao menos, desde 25 de agosto de 1992, com a promulgação da emenda constitucional $n^{\circ} 2$, que dispôs sobre o plebiscito previsto no artigo $2^{\circ}$ do Ato das Disposições Constitucionais Transitórias sem alteração do texto constitucional. Pode-se afirmar, dessa forma, que ganhou importância no direito brasileiro a noção de bloco de constitucionalidade após a inserção dos tratados internacionais de direitos humanos em seu objeto.

Nesse sentido, afirma José Carlos Francisco, in literis:

O ordenamento constitucional passa a ser composto do texto positivado e pelos elementos implícitos inseridos no corpo permanente e no Ato das Disposições Constitucionais Transitórias (ADCT) pelo constituinte de 1988, pelos preceitos expressos e implícitos constantes apenas nas emendas constitucionais ordinárias elaboradas nos termos do art. 60 e nas emendas de revisão produzidas com amparo no art. $3^{\circ}$ do ADCT (vale dizer, dispositivos constitucionais que não foram introduzidos no corpo permanente ou no ADCT, mas que têm

\footnotetext{
${ }^{352}$ Cf. Louis Favoreu, Le controle, p.51. Leciona Favoreu, Le controle, p.54-56, apresentando decisões do Conselho constitucional francês que, no direito gaulês, os tratados internacionais não integram o bloco de constitucionalidade. Eva Bruce, Faut-il intégrer, p.544, ao comentar a não inclusão dos tratados internacionais como parâmetro do controle de constitucionalidade, registra que essa decisão fundamentase no argumento de que estes são "relativos e contingenciais", ao passo que as normas constitucionais são "absolutas e definitivas"; discute a autora, contudo, p.540-543, a possibilidade de normas comunitárias, fundadas no artigo 88, 1, da Constituição francesa comporem o bloco de constitucionalidade, em atenção ao artigo 61 do texto constitucional francês, que atribui ao Conselho Constitucional a missão de guarda da Constituição.
} 
hierarquia constitucional) e, agora, também pelos preceitos expressos e implícitos contidos nos tratados e convenções internacionais sobre direitos humanos aprovados nos moldes do $\S 3^{\circ}$ do art. $5^{\circ}$ do ordenamento constitucional. Dessa reunião de diplomas normativos, todos com hierarquia constitucional, o sistema jurídico brasileiro passa a se valar da noção de bloco de constitucionalidade, qual seja Constituição em sentido formal e material (portanto, hierárquico, permitindo o controle de constitucionalidade em decorrência da Supremacia da Constituição) que agora representa a reunião de diplomas normativos diversos, ainda que não consolidados em um único “código",353.

Outra possível decorrência da incorporação dos tratados internacionais de direitos humanos com posição hierárquica constitucional seria uma maior relativização da organicidade da Constituição da República Federativa do Brasil.

Constituição orgânica, no entendimento de Elival da Silva Ramos, é a que se consubstancia em um ato unitário, organicamente articulado, não afetando, para o autor, o seu caráter orgânico “as sucessivas revisões de seu texto por meio de emendas, já que estas sempre se reportam ao texto unitário inicial”354. Sem dúvidas, não há quebra da organicidade do texto constitucional nos casos em que emenda constitucional altera dispositivo constitucional; não há igualmente, nos casos em que o texto da emenda não é integrado ao texto constitucional, como é o artigo $2^{\circ}$ da emenda constitucional $n^{\circ}$ 32/01, quebra da organicidade, ainda que de maneira reduzida, pois é o próprio texto constitucional que se reporta a esses outros textos de semelhante posição hierárquica constitucional e estes, da mesma maneira, fazem referência ao texto unitário inicial, ainda que não o integrem.

Nessa mesma linha deve dirigir-se a análise sobre uma possível quebra da organicidade do texto constitucional com a introdução dos tratados internacionais de direitos humanos na Constituição formal da República Federativa do Brasil.

É a própria Constituição de 1988, em seu artigo 5º $§ 3^{\circ}$, que atribui aos tratados internacionais de direitos humanos, aprovados pelo procedimento nele previsto, posição

\footnotetext{
${ }^{353}$ Bloco de constitucionalidade, p.100.

${ }^{354}$ A inconstitucionalidade, p.52, em especial, nota de rodapé 103.
} 
hierárquica constitucional. Assim como a Constituição francesa de 1958, a Constituição de 1946, a Declaração dos Direitos do Homem e do Cidadão de 1789 e os princípios fundamentais reconhecidos pelas leis da República formam o bloco de constitucionalidade francês, sem quebra da organicidade do texto constitucional, pois chega-se ao conteúdo desse bloco partindo-se de referência do próprio texto constitucional de 1958, os tratados internacionais de direitos humanos, aprovados pelo procedimento previsto no artigo $5^{\circ}, \S 3^{\circ}$, da Constituição da República Federativa do Brasil de 1988, compõem o bloco de constitucionalidade brasileiro, sem quebra da organicidade do texto constitucional, pois chega-se ao conteúdo desse bloco igualmente partindo-se de referência do próprio texto constitucional de 1988.

Em suma, ganha relevo, com a reforma de 2004, a noção de bloco de constitucionalidade no direito brasileiro, sem prejuízo da organicidade do texto constitucional. 


\section{CONCLUSÃo.}

Uma leitura atenta dos textos de Triepel, de Anzilotti e de Kelsen traz informações imprescindíveis para a construção teórica dos modelos de relações entre direito interno e direito internacional. Essas informações, por motivos que se desconhece, perderam-se; os textos recentes, por exemplo, apontam a possibilidade de aplicação de atos normativos internacionais no âmbito territorial nacional como critério distintivo entre monismo e dualismo, o que se mostrou equivocado.

Demonstrou-se que o modelo monista é incompatível com a existência de poder soberano estatal, vez que se assenta na existência de uma única ordem jurídica global, uma única fonte jurídica, que delega competências às diversas ordens parciais, que, dentro dessa estrutura idealizada, estão a ela subordinadas.

Prevalece, assim, o modelo dualista, que se fundamenta na existência de fontes jurídicas diversas, uma internacional e diversas estatais, mas com algumas nuances, em razão do concerto internacional atual: as normas internas e as normas internacionais não mais se diferenciam por seu conteúdo, pois o direito internacional não mais regula somente as relações entre os Estados-nacionais, prescrevendo igualmente normas que têm por destinatários pessoas humanas. Decorrem da adoção do modelo dualista a possibilidade de um ato normativo internacional ser aplicado no âmbito interno, a possibilidade de conflito entre normas de direito interno e de direito internacional, que se resolvem não pela revogação, mas pela suspensão da aplicação de um ou de outro, mantendo-se a responsabilização estatal no caso de descumprimento de compromisso assumido internacionalmente.

No direito estrangeiro, sobretudo no direito constitucional argentino, reformado em 1994, buscaram-se subsídios para o trabalho.

Dos textos constitucionais estrangeiros, de maneira geral, extrai-se certa regularidade no procedimento de celebração dos tratados internacionais. Em regra, são os tratados negociados, assinados e ratificados, após deliberação do Legislativo, pelo Chefe de Estado e, após sua incorporação, têm, como regra geral, posição hierárquica infraconstitucional.

O texto constitucional argentino, por sua vez, foi fonte de inspiração direta para a reforma brasileira de 2004, que introduziu o $\S 3^{\circ}$ ao artigo $5^{\circ}$ da Constituição. A reforma constitucional argentina, como analisado, foi mais completa que a brasileira, 
pois atribuiu expressamente posição hierárquica constitucional a tratados internacionais de direitos humanos incorporados anteriormente à reforma, em seu artigo 75, 22. Na reforma brasileira, a não atribuição expressa nesse sentido fez surgir discussão sobre a posição hierárquica dos tratados internacionais de direitos humanos incorporados anteriormente pela República Federativa do Brasil. Perdeu o legislador nacional a oportunidade de equacionar de maneira mais adequada a questão da posição hierárquica dos tratados internacionais de direitos humanos.

No direito brasileiro, analisaram-se, inicialmente, as disposições constitucionais que tratam dos fundamentos e dos objetivos da República Federativa do Brasil, bem como os princípios regentes de suas relações internacionais. Retira-se desse capítulo a base principiológica sobre a qual ancora-se toda a atuação da República Federativa do Brasil nos procedimentos de celebração e incorporação dos tratados internacionais de direitos humanos. Procurou-se atribuir aos dispositivos constitucionais interpretação sistemática e harmônica, afastando-se conflitos eventual e equivocadamente levantados entre princípios nacionalistas e internacionalistas, mais especificamente entre soberania estatal e proteção dos direitos humanos. O exercício do poder soberano estatal, vinculado que deve ser à finalidade estatal do bem comum, não leva a violações de direitos humanos.

A inclusão do $\S 3^{\circ}$ do artigo $5^{\circ}$ da Constituição da República Federativa, em tentativa de pôr fim à celeuma doutrinária e jurisprudencial instalada no direito brasileiro, trouxe respostas, mas também muitas dúvidas.

Com relação ao procedimento de celebração dos tratados internacionais de direitos humanos, criou-se uma certa dificuldade para a identificação de um tratado internacional como sendo de direitos humanos, para os fins do artigo $5^{\circ}, \S 3^{\circ}$, da Constituição, o que se determinará, de maneira conjunta, por meio do conteúdo que dá o Presidente da República à mensagem enviada ao Congresso Nacional, acompanhada por exposição de motivos do Ministro das Relações Exteriores, e do relatório apresentado pela Comissão de Relações Exteriores da Câmara de Deputados. O procedimento pelo qual será apreciado o tratado internacional depende dessa conjugação de vontades, partindo-se da não-obrigatoriedade desse novo procedimento.

Com relação ao procedimento de incorporação, a equivalência dos tratados internacionais de direitos humanos às emendas constitucionais traz novo argumento à desnecessidade de promulgação e publicação desses tratados, por meio de decreto do Chefe do Executivo, sendo suficiente a publicação do decreto legislativo. 
Por fim, a prescrição constitucional que atribui equivalência às emendas constitucionais aos tratados internacionais de direitos humanos aprovados pelo procedimento diferenciado nele previsto reforça a existência de um bloco de constitucionalidade no controle de constitucionalidade brasileiro, pois esses tratados, ao lado do texto orgânico de 1988 e dos dispositivos das mais de cinqüenta emendas que não integraram o texto constitucional, são parâmetro para o controle de constitucionalidade dos atos normativos, sem prejuízo da organicidade do texto constitucional. 


\section{REFERÊNCIAS.}

Doutrina.

AlmeidA, Fernanda Dias Menezes de. A incorporação dos tratados internacionais ao ordenamento jurídico brasileiro. Análise do tema à luz do direito constitucional, in Revista do advogado. São Paulo, ano 23, $\mathrm{n}^{0}$ 73, novembro de 2003, p.48-58.

. Competências na Constituição de 1988. $2^{\mathrm{a}}$ ed., São

Paulo, Atlas, 2000.

AlmeidA, Paulo Roberto de. Relações exteriores e Constituição, in Revista de informação legislativa. Brasília, ano 24, no 94, abril-junho de 1987, p.109-120.

Almirón Prujel, María Elodia. Los derechos humanos y la Constitución Nacional, in El Paraguay frente al sistema internacional de los derechos humanos. Coord. Cynthia González Feldmann. Montevideo, Fundación Konrad Adenauer, 2004, p.27-40.

AlONSO GARCíA, Ricardo. El juez español y el derecho comunitario: jurisdicciones constitucional y ordinaria frente a su primícia y eficacia. Madri, Consejo General del Poder Judicial, 2003.

Amaral Júnior, José Levi Mello do. Os tratados no ordenamento jurídico brasileiro, in Direito \& Justiça. Porto Alegre, v. 23, ano 23, 2001, p.175-199.

ANDRADA, Fátima. Instituciones internas de protección de los derechos humanos, in El Paraguay frente al sistema internacional de los derechos humanos. Coord. Cynthia González Feldmann. Montevideo, Fundación Konrad Adenauer, 2004, p.41-53. 
AnZILOTTI, Dionisio. Corso di Diritto Internazionale - Introduzione - I soggetti - Gli organi. Roma, Athenaeum, 1923.

ARAúJo, Nadia de. A internacionalização dos tratados internacionais no direito brasileiro e a ausência de regulamentação constitucional, in Revista de Direito da Associação dos Procuradores do Novo Estado do Rio de Janeiro. Rio de Janeiro, v. 15, 2005, p.1-15.

BAPTISTA, Luiz Olavo. Chronique de jurisprudence brésillienne, in Journal du droit international. Paris, t. 108, julho-agosto-setembro de 1981, p.599-607. . Inserção dos tratados no direito brasileiro, in Revista de informação legislativa. Brasília, ano 33, n 132, outubro-dezembro de 1996, p.p.7180 .

BIDART CAMPOS, German J.. Tratado elemental de derecho constitucional argentino. Tomo III - El derecho internacional de los Derechos Humanos y la reforma constitucional de 1994. 9a ed., Buenos Aires, Sociedad Anonima Editora Comercial, Industrial y Financiera, 1995.

Binembojnt, Gustavo. Monismo e dualismo no Brasil: uma dicotomia afinal irrelevante, in Revista de direito da Associação dos Procuradores do novo Estado do Rio de Janeiro. Rio de Janeiro, v. 15, 2005, p.17-31.

BobBio, Norberto. O positivismo jurídico - Lições de filosofia do direito. Trad. Márcio Pugliesi, Edson Bini, Carlos E. Rodrigues. São Paulo, Ícone, 1995. . Teoria do ordenamento jurídico. Trad. Maria Celeste Leite Cordeiro dos Santos. 10ª ed., Brasília, UnB, 1999.

Bonavides, Paulo. Ciência política. 10ª ed., São Paulo, Malheiros, 2004. . Teoria do Estado. 5a ed., São Paulo, Malheiros, 2004. 
BRUCE, Eva. Faut-il intégrer le droit communautaire aux normes de référence du controle de constitutionnalité?, in Revue française de droit constitutionnel. Paris, $\mathrm{n}^{\circ}$ 63, 2005, p.539-560.

Bustamante, Thomas da Rosa de. A impossibilidade de denúncia de tratados internacionais por ato privativo do Presidente da República: uma análise crítica dos argumentos dominantes sobre o assunto, in Revista de direito constitucional $e$ internacional. São Paulo, ano 12, nº 46, janeiro-março de 2004, p.339-346.

Cachapuz de Medeiros, Antônio Paulo. O poder de celebrar tratados competência dos poderes constituídos para a celebração de tratados, à luz do Direito Internacional, do Direito Comparado e do Direito Constitucional Brasileiro. Porto Alegre, Sergio Antonio Fabris, 1995.

Caggiano, Monica Herman Salem. Oposição na política. São Paulo, Angelotti, 1995. - Emenda constitucional n. 45/2004, in Revista brasileira de direito constitucional. São Paulo, nº 5, janeiro-junho de 2005, p.185-204.

CALMON DE PASSOS, Jorge Luiz Ieski. Direitos humanos e reforma do Judiciário, in Reforma do Judiciário: primeiras reflexões sobre a emenda constitucional n. 45/2004. Coord. Teresa Arruda Alvim Wambier, Luiz Rodrigues Wambier e outros. São Paulo, RT, 2005, p.349-353.

CAMPOS, Francisco. Parecer: imposto de vendas e consignações - incidência em sobretaxas cambiais - ágios e bonificações - acordos internacionais sobre paridade cambial, in Revista de direito administrativo. Rio de Janeiro, $\mathrm{n}^{\circ}$ 47, dezembro de 1956, p.452-458.

CançAdo Trindade, Antônio Augusto. A proteção internacional dos direitos humanos e o Brasil. 2a ed., Brasília, Editora UnB, 2000. - Tratado de direito internacional dos direitos humanos. Vol. I, Porto Alegre, Fabris, 1997. 
CANOtIlHo, Joaquim José Gomes. Direito constitucional e teoria da Constituição. $7^{\mathrm{a}}$ ed., Coimbra, Almedina, 2003.

Carrazza, Roque Antonio. Curso de direito constitucional tributário. 18a ed., São Paulo, Malheiros, 2002.

CAstro, Amílcar de. Direito internacional privado. $5^{\mathrm{a}}$ ed., Rio de Janeiro, Forense, 1995.

ChevalLier, Jean-Jacques. As grandes obras políticas de Maquiavel a nossos dias. Trad. Lydia Cristina. 8a ed., Rio de Janeiro, Agir, 2002.

ClÉment, Zlata Drnas de. Los documentos internacionales del ámbito regional incorporados a la Constitución Nacional, in Anuário argentino de derecho internacional. Cordoba, v. 6, 1994-1995, p.193-207.

Comparato, Fábio Konder. Vigência das Convenções de Genebra sobre letras de câmbio, promissórias e cheques, in Revista dos tribunais. São Paulo, $\mathrm{n}^{\circ}$ 390, abril de 1968, p.48-57.

Dallari, Dalmo de Abreu. Os direitos fundamentais na Constituição brasileira, in Revista da Faculdade de Direito da Universidade de São Paulo. São Paulo, v. 88, 1993, p.421-437. Elementos de teoria geral do Estado. $21^{\text {a }}$ ed., São Paulo, Saraiva, 2000.

DALlARI, Pedro Bohomoletz de Abreu. Constituição e relações exteriores. São Paulo, Saraiva, 2002. . Constituição e tratados internacionais. São Paulo, Saraiva, 2003. 
. Tratados internacionais na Emenda Constitucional 45, in Reforma do Judiciário - analisada e comentada. Coord. André Ramos Tavares, Pedro Lenza e Pietro de Jesús Lora Alarcón. São Paulo, Método, 2005, p.83-98.

DiEz-PICAzo, Luis Maria. El derecho comunitário en la jurisprudencia constitucional española, in Revista española de derecho constitucional. Madri, ano 18, $n^{\circ} 54$, setembro-dezembro de 1998, p.255-272.

Dinamarco, Cândido Rangel. Instituições de direito processual civil. Vol. 4, Execução forçada, São Paulo, Malheiros, 2004.

Dinh, Nguyen Quoc, Daillier, Patrick, Pellet, Alain. Droit international public. $5^{\mathrm{a}}$ ed., Paris, LGDJ, 1994.

DoLINGER, Jacob. As soluções da Suprema Corte brasileira para os conflitos entre o direito interno e o direito internacional: um exercício de ecletismo, in Revista forense. Rio de Janeiro, v. 334, abril-junho de 1996, p.71-107. . Direito internacional privado. Parte geral. $7^{\mathrm{a}}$ ed., Rio de Janeiro, Renovar, 2003.

DONAIRE VILlA, Francisco Javier. El tratado de Amsterdam y la Constitución, in Revista española de derecho constitucional. Madri, ano 18, $\mathrm{n}^{0} 54$, setembro-dezembro de 1998, p.119-167.

DuARTE, Leonardo Avelino. Estudos sobre a posição hierárquica dos decretos legislativos que incorporam tratados, in Revista de direito constitucional $e$ internacional. São Paulo, ano 10, nº 41, outubro-dezembro de 2002, p.69-96.

FAVOREU, Louis. Le controle de constitutionnalité du traité de Maastricht et le developpement $d u$ "droit constitutionnel international", in Revue generale de droit international public. Paris, v. 97, 1993, p.39-66. 
FERreIRA, Luiz Alexandre Cruz, Tárrega, Maria Cristina Vidotte Blanco. Reforma do Poder Judiciário e direitos humanos, in Reforma do Judiciário: primeiras reflexões sobre a emenda constitucional n. 45/2004. Coord. Teresa Arruda Alvim Wambier, Luiz Rodrigues Wambier e outros. São Paulo, RT, 2005, p.447-466.

FERreira Filho, Manoel Gonçalves. Comentários à Constituição brasileira de 1988. Vol. 1 - artigos $1^{0}$ a 103. $3^{\text {a }}$ ed., São Paulo, Saraiva, 2000.

. Comentários à Constituição brasileira de 1988. Vol. 2 - artigos 104 a 250. $2^{\text {a }}$ ed., São Paulo, Saraiva, 1999. . Curso de direito constitucional. 32a ed., São Paulo, Saraiva, 2006. . Direitos humanos fundamentais. $7^{\mathrm{a}}$ ed., São Paulo, Saraiva, 2005. O poder constituinte. $3^{\mathrm{a}}$ ed., São Paulo, Saraiva, 1999.

FONSECA, José Roberto Franco da. Especificidades das regras jurídicas internacionais, in Dimensão internacional do direito - Estudos em homenagem a G. E. do Nascimento e Silva. Coord. Paulo Borba Casella. São Paulo, LTr, 2000, p.201-210.

FRANCISCO, José Carlos. Bloco de constitucionalidade e recepção dos tratados internacionais, in Reforma do Judiciário - analisada e comentada. Coord. André Ramos Tavares, Pedro Lenza e Pietro de Jesús Lora Alarcón. São Paulo, Método, 2005, p.99-105.

FrotA, Hidemberg Alves da. Os tratados de proteção internacional aos direitos humanos na reforma do Poder Judiciário, in Revista CEJ. Brasília, $\mathrm{n}^{\circ}$ 30, julhosetembro de 2005, p.5-9.

GABRIEL, Amélia Regina Mussi. Hierarquia jurídica da norma internacional de direitos humanos em face do art. $5^{\circ}, \S 3^{\circ}$, da Constituição brasileira, in Revista de informação legislativa. Brasília, ano 42, nº 165, janeiro-março de 2005, p.255-265. 
GARCIA, Maria. Tratados internacionais. Denúncia. Necessidade da participação do Poder Legislativo. O princípio constitucional da participação dos Poderes, in Cadernos de direito constitucional e ciência política. São Paulo, v.5, nº 21, outubro-dezembro de 1997, p.92-97.

Gomes, Luiz Flávio. A questão da obrigatoriedade dos tratados e convenções no Brasil (particular enfoque na Convenção Americana sobre Direitos Humanos), in Revista dos tribunais. São Paulo, ano 83, v. 710, dezembro de 1994, p.21-31.

GonZÁlez, Carmen. El relanzamiento del Mercosur y la incorporación de sus normas en los ordenamientos jurídicos internos, con especial referencia al Uruguay, in Revista de direito da Associação dos Procuradores do novo Estado do Rio de Janeiro. Rio de Janeiro, v. 15, 2005, p.57-80.

GonZÁlez FeldMANN, Cynthia. La implementación de tratados internacionales de derechos humanos por el Paraguay, in El Paraguay frente al sistema internacional de los derechos humanos. Coord. Cynthia González Feldmann. Montevideo, Fundación Konrad Adenauer, 2004, p.17-26.

GraU, Eros Roberto. A ordem econômica na Constituição de 1988. $7^{\mathrm{a}}$ ed., São Paulo, Malheiros, 2002.

HoRTA, Raul Machado. Direito constitucional. $3^{\mathrm{a}}$ ed., Belo Horizonte, Del Rey, 2002.

IAnNI, Octavio. Teorias da globalização. $8^{a}$ ed., Rio de Janeiro, Civilização Brasileira, 2000.

KelSEN, Hans. Les rapports de système entre le droit interne et le droit internacional public, in Recueil des cours de l'Académie de Droit International. Haia, n. 4, 1926, 227-331. 
Teoria pura do direito. Trad. João Baptista Machado.

6 ${ }^{\mathrm{a}}$ ed., São Paulo, Martins Fontes, 2003.

Kronenberger, Vincent. A new approach to the interpretation of the french Constitution in respect to international conventions: from hierarchy of norms to conflict of competence, in Netherlands international law review. Haia, $\mathrm{n}^{\circ}$ 47, 2000, p.323-358.

LAFER, Celso. Comércio e relações internacionais. São Paulo, Perspectiva, 1977.

LeMBO, Cláudio. A pessoa: seus direitos. Barueri, Manole, 2007.

LEWANDOWSKI, Enrique Ricardo. A proteção dos direitos humanos no Mercosul, in Direitos humanos, globalização econômica e integração regional Desafios do Direito Constitucional Internacional. Coord. Flávia Piovesan. São Paulo, Max Limonad, 2002, p. 255-283.

LOPES, Soraya Santos. A efetividade dos direitos humanos e a emenda consttiucional n. 45, in Reforma do Judiciário. Coord. Fredie Didier Jr., Edvaldo Brito e Saulo José Casali Bahia. São Paulo, Saraiva, 2006, p.261-288.

LuCHAIRE, Françoise. Le traité d'Amsterdam et la Constitution, in Revue de droit public et de science politique en France et à l'etranger. Paris, $\mathrm{n}^{\circ} 2$, março-abril de 1998, p.331-350.

Magalhães, José Carlos de. Lex mercatoria, in Revista dos tribunais. São Paulo, no 709, novembro de 1994, p.42-45.

- O Supremo Tribunal Federal e as relações entre direito interno e internacional, in Boletim brasileiro de direito internacional. São Paulo, anos 31 a 36, $\mathrm{n}^{\circ}$ 61/66, 1975/1979, p.53-57.

O Supremo Tribunal Federal e o direito internacional - uma análise crítica. Porto Alegre, Livraria do Advogado, 2000. 
MaiA Filho, Gastão de Moura. Os títulos de crédito e as Convenções de Genebra, in Revista dos tribunais. São Paulo, nº 387, janeiro de 1968, p.354-356.

MARTINS, Fernando Corrêa. Emendas constitucionais decorrentes do processo de globalização e integração econômica (tratados internacionais) na Argentina, in Revista de direito constitucional e internacional. São Paulo, v. 10, n. 38, janeiro-março de 2002, p.46-60.

MAsCAREnHAs, Rodrigo Tostes de Alencar. O conflito entre a Constituição e os tratados internacionais: sob a ótica internacional e perante os ordenamentos constitucionais brasileiro e argentino, in Revista da Faculdade de Direito da Universidade Católica de Petrópolis. Rio de Janeiro, v. 1, 1999, p.77-91.

MAssoud, Carolina Ormanes. Hierarquia das normas sobre tratados $e$ convenções internacionais sobre direitos humanos, in Reforma do Judiciário comentada. Coord. Zeno Veloso e Gustavo Vaz Salgado. São Paulo, Saraiva, 2005, p.610 .

Mazzuoli, Valério de Oliveira. A influência dos tratados internacionais de proteção aos direitos humanos no direito interno brasileiro e a primazia da norma mais favorável como regra de hermenêutica internacional, in Revista da Procuradoria Geral do Estado de São Paulo. São Paulo, nº 53, junho de 2000, p.83-106. A opção do Judiciário brasileiro em face dos conflitos entre tratados internacionais e leis internas, in Revista CEJ. Brasília, $\mathrm{n}^{\circ} 14$, maioagosto de 2001, p.112-120.

O Poder Legislativo e os tratados internacionais: o treaty-making power na Constituição brasileira de 1988, in Revista de direito constitucional e internacional. São Paulo, ano 10, $n^{\circ}$ 38, janeiro-março de 2002, p.9-45.

MeIRELES, Ana Cristina Costa. $O \oint 3^{\circ}$ do art. $5^{\circ}$ da CF/88 e os direitos sociais. Reflexões e perplexidades, in Reforma do Judiciário. Coord. Fredie Didier Jr., Edvaldo Brito e Saulo José Casali Bahia. São Paulo, Saraiva, 2006, p.1-30. 
Mello, Celso D. de Albuquerque. Curso de direito internacional público. $13^{\mathrm{a}}$ ed., v. I, Rio de Janeiro, Renovar, 2001. . Direito constitucional internacional. $2^{\mathrm{a}}$ ed., Rio de Janeiro, Renovar, 2000. - Ratificação de tratados. Rio de Janeiro, Freitas Bastos, 1966.

Mendes, Gilmar Ferreira, Coelho, Inocêncio Mártires, Branco, Paulo Gustavo Gonet. Curso de direito constitucional. São Paulo, Saraiva, 2007.

MiRANDA, Jorge. As relações entre ordem internacional e ordem interna na actual Constituição portuguesa, in Arquivos do Ministério da Justiça. Lisboa, ano 49, n. 188, julho-dezembro de 1996, p.131-155.

Teoria do Estado e da Constituição. Rio de Janeiro, Forense, 2002.

Monteiro, Marco Antonio Corrêa. Análise comparativa dos direitos previstos na Convenção Americana sobre direitos humanos - Pacto de São José da Costa Rica e na Constituição Federal brasileira de 1988, in Revista brasileira de direito constitucional. São Paulo, n. 4, julho-dezembro de 2004, p.679-720.

O impacto da emenda constitucional n. 45/04 na doutrina brasileira sobre a incorporação ao direito interno e o "status" dos tratados internacionais de direitos humanos. São Paulo, Escola Superior de Direito Constitucional, Trabalho de Conclusão de Curso de Especialização, 2006.

MoraEs, Alexandre de. Direitos humanos fundamentais. $3^{\mathrm{a}}$ ed., São Paulo, Atlas, 2000. Direito constitucional. 22ª ed., São Paulo, Atlas, 2007.

OnAINDIA, José Miguel. Bloque de constitucionalidad, in Revista brasileira de direito constitucional. São Paulo, nº 6, julho-dezembro de 2005, p.488-494. 
PÉREZ TREMPS, Pablo. Las condiciones constitucionales al proceso de ratificación del Tratado de Maastricht en el derecho comparado, in Revista de la Facultad de Derecho de la Universidad Complutense. Madri, nº 18, 1994, p.51-85. . Constitución española y Unión Europea, in Revista española de derecho constitucional. Madri, ano 24, $\mathrm{n}^{\circ}$ 71, maio-agosto de 2004, p.103121.

PIERA, Alejandro. La incorporación de la normativa del Mercosur en el derecho positivo paraguayo, in Revista de direito da Associação dos Procuradores do novo Estado do Rio de Janeiro. Rio de Janeiro, v. 15, 2005, p.81-90.

Piovesan, Flávia. Direitos humanos e o direito constitucional internacional. São Paulo, Max Limonad, 2002.

. Reforma do Judiciário e direitos humanos, in Reforma do Judiciário - analisada e comentada. Coord. André Ramos Tavares, Pedro Lenza e Pietro de Jesús Lora Alarcón. São Paulo, Método, 2005, p.67-81.

RAmOS, Elival da Silva. A ação popular como instrumento de participação política. São Paulo, RT, 1991.

A inconstitucionalidade das leis: vício e sanção. São Paulo, Saraiva, 1994.

A proteção aos direitos adquiridos no direito constitucional brasileiro. São Paulo, Saraiva, 2003.

- Perspectivas de evolução do controle de constitucionalidade no Brasil. São Paulo, Faculdade de Direito da Universidade de São Paulo, Departamento de Direito do Estado, Tese de Titularidade, 2005.

RANGEL, Vicente Marotta. Os conflitos entre o direito interno e os tratados internacionais, in Boletim da sociedade brasileira de direito internacional. Rio de Janeiro, v. 23, nos 45 e 46, janeiro-dezembro de 1967, p.29-64.

. Direito e relações internacionais. $7^{\mathrm{a}}$ ed., São Paulo, RT, 2002. 
La procédure de conclusions des accords internationaux au Brésil, in Revista da Faculdade de Direito da Universidade de São Paulo. São Paulo, ano 55, 1960, p.253-271.

REALE, Miguel. Lições preliminares de direito. 24a ed., São Paulo, Saraiva, 1999. Teoria do Direito e do Estado. 5a ed., São Paulo, Saraiva, 2003.

RechSteIner, Beat Walter. Direito internacional privado. $8^{\text {a }}$ ed., São Paulo, Saraiva, 2005.

Renault, Sérgio Rabello Tamm, Bottini, Pierpaolo. Primeiro passo, in Reforma do Judiciário. Coord. Sérgio Rabello Tamm Renault e Pierpaolo Bottini. São Paulo, Saraiva, 2005, p.1-12.

REQUiño, Rubens. Cambial: invalidade de lei que exige seu registro, in Revista de direito mercantil industrial, econômico e financeiro. São Paulo, ano 10, nova série, $\mathrm{n}^{\mathrm{o}} 1,1971, \mathrm{p} .13-28$.

Rey CARO, Ernesto J.. Los tratados internacionales en el ordenamiento jurídico argentino. Consideraciones sobre la reforma constitucional, in Anuario argentino de derecho internacional. Córdoba, v. 6, 1994-1995, p.209-239.

REZEK, José Francisco. Direito internacional público. $11^{\mathrm{a}}$ ed., São Paulo, Saraiva, 2008.

Direito dos tratados. Rio de Janeiro, Forense, 1984.

. Tratados e suas relações com o ordenamento jurídico interno: antinomia e norma de conflito, in Revista CEJ. Brasília, v. 1, $\mathrm{n}^{\circ}$ 2, maio-agosto de 1997, p.54-59.

RIDEAU, Joël. Les procédures de ratification du traité sur l'Union européenne, in Revue française de droit constitutionnel. Paris, $\mathrm{n}^{\circ}$ 12, 1992, p.611-624. 
RoDAs, João Grandino. A constituinte e os tratados internacionais, in Revista dos tribunais. Rio de Janeiro, ano 76, vol. 624, outubro de 1987, p.43-51.

- Tratados internacionais. Sua executoriedade no

direito interno brasileiro, in Revista do curso de direito da Universidade Federal da Uberlândia. Uberlândia, v. 21, nº 1/2, dezembro de 1992, p.311-323.

SALAS, Graciela R.. Los pactos internacionales incorporados a la Constitución Nacional, in Anuário argentino de derecho internacional. Cordoba, v. 6, 1994-1995, p.175-192.

Savioli, Fabián. La Constitución de la Nación Argentina y los derechos humanos - Un análisis a la luz de la Reforma de 1994. Buenos Aires, Moimento Ecuménico por los Derechos Humanos, 1995.

Silva, José Afonso da. A dignidade da pessoa humana como valor supremo da democracia, in Revista de direito administrativo. Rio de Janeiro, n. 212, abril-junho de 1998, p.89-94.

. Comentário contextual à Constituição. São Paulo, Malheiros, 2005.

Curso de direito constitucional positivo. $18^{\mathrm{a}}$ ed., São

Paulo, Malheiros, 2000.

- Poder constituinte e poder popular. São Paulo,

Malheiros, 2002.

SILVA, Virgílio Afonso. A constitucionalização do direito. Os direitos fundamentais nas relações entre particulares. São Paulo, Malheiros, 2005.

SoAREs, Guido Fernando Silva. Curso de direito internacional público. São Paulo, Atlas, 2002.

SouZA, Maria Paula Alves de. Integração dos tratados internacionais de direitos humanos no ordenamento jurídico brasileiro. Uma análise em face das alterações trazidas pela Emenda Constitucional $n^{\circ}$ 45/2004. São Paulo, Faculdade de 
Direito da Universidade de São Paulo, Departamento de Direito Internacional, Tese de Láurea, 2006.

Tavares, André Ramos. Reforma do Judiciário no Brasil pós-88. São Paulo, Saraiva, 2005.

TENóRIO, Oscar. Direito internacional privado. Rio de Janeiro, Editora Nacional, 1942.

Tiburcio, Carmen. A EC n. 45 e temas de direito internacional, in Reforma do Judiciário: primeiras reflexões sobre a emenda constitucional n. 45/2004. Coord. Teresa Arruda Alvim Wambier, Luiz Rodrigues Wambier e outros. São Paulo, RT, 2005, p.121-139.

TÔRREs, Heleno Taveira. Aplicação dos tratados e convenções internacionais em matéria tributária no direito brasileiro, in Tratados internacionais na ordem jurídica brasileira. Antonio Carlos Rodrigues do Amaral. São Paulo, Lex Editora Aduaneira, 2005, p.141-174.

TRIEPEL, Heinrich. Les rapports entre le droit interne et le droit international, in Recueil des cours de l'Académie de Droit International. Haia, n. 1, 1923, p.73-121.

VAlladÃo, Haroldo. Direito internacional privado. 5a ed., Rio de Janeiro, Freitas Bastos, 1980.

Velloso, Carlos Mário da Silva. Tratados internacionais na jurisprudência do Supremo Tribunal Federal, in Tratados internacionais na ordem jurídica brasileira. Coord. Antonio Carlos Rodrigues do Amaral. São Paulo, Lex Editora - Aduaneira, 2005, p.13-30.

Verdross, Alfred. Derecho internacional publico. Trad. Antonio Truyol y Serra. $5^{\text {a }}$ ed., Madri, Aguilar, 1974. 
VIEIRA, Oscar Vilhena. Direitos humanos - Estado de Direito e construção da paz. Coord. Oscar Vilhena Vieira. São Paulo, Quartier Latin, 2005. . Direitos fundamentais - uma leitura da jurisprudência do STF. Colaboração de Flávia Scabin. São Paulo, Malheiros, 2006.

WEBER, Albrecht. El control del Tratado de Maastricht por la jurisdiccion constitucional desde una perspectiva comparada, in Revista española de derecho constitucional. Trad. Germán Gómez Orfanel. Madri, ano 15, nº 45, setembro-dezembro de 1995, p.31-51.

ZIULU, Adolfo Gabino. La globalización, los tratados internacionales y la Constitución, in Anales de la Facultad de Ciencias Jurídicas y Sociales de la Universidad Nacional de la Plata. La Plata, v. 33, 1997, p.61-77.

Jurisprudência.

Corte Suprema de Justicia de la NAción - Argentina. Luis Ledesma c/ Provincia de Santiago del Estero, s/ daños y perjuicios, in www.csjn.gov.ar, acesso em 29 de dezembro de 2006. Causa julgada em 11 de julho de 2006. . Maria Graciela Dieser y Carlos Andrés Fraticelli, s/ homicidio calificado por el vínculo y por alevosia, in www.csjn.gov.ar, acesso em 29 de dezembro de 2006. Causa n. 120/02, julgada em 8 de agosto de 2006.

Supremo Tribunal Federal - Brasil. Apelação Cível $n^{0}$ 7.872-RS, in Arquivo Judiciário, n. 69, p.13-25. Relator Ministro Philadelpho Azevedo, 11 de outubro de 1943. 
- Conflito de Jurisdição $n^{\circ}$ 4.663-SP, in Revista

Trimestral de Jurisprudência, n. 48, p.76-78. Relator Ministro Eloy da Rocha, Terceira Turma, 17 de maio de 1968. - Recurso Extraordinário $n^{\circ} 71.154-P R$, in Revista

Trimestral de Jurisprudência, n. 58, p.70-74. Relator Ministro Oswaldo Trigueiro, Tribunal Pleno, 4 de agosto de 1971.

Recurso Extraordinário $n^{o}$ 80.004-SE, in Revista

Trimestral de Jurisprudência, n. 33, p.809-848. Relator Ministro Xavier de Albuquerque, Tribunal Pleno, $1^{\circ}$ de junho de 1977.

Ação Direta de Inconstitucionalidade $n^{\circ} 1.480$ MC-

DF, in www.stf.gov.br, acesso em 27 de agosto de 2004. Relator Ministro Celso de Mello, Tribunal Pleno, 4 de setembro de 1997.

Agravo Regimental no Agravo de Instrumento $n^{o}$ 513.044-5-SP, in www.stf.gov.br, acesso em 7 de janeiro de 2008. Relator Ministro Carlos Mário Velloso, Segunda Turma, 22 de fevereiro de 2005.

. Habeas Corpus $n^{\circ}$ 90.172-7-SP, in www.stf.gov.br, acesso em 11 de janeiro de 2008. Relator Ministro Gilmar Mendes, Segunda Turma, 5 de junho de 2007.

Textos normativos.

CONSTITUCIÓN DE LA NACIÓN ARgENTINA DE 1853, in www.senado.gov.ar. Acesso em 30 de dezembro de 2006.

Constitución DE LA Republica de Paraguay DE 1992, in www.camdip.gov.py. Acesso em 30 de dezembro de 2006.

Constitución de LA República ORIEntal DEL URUguay DE 1967, in www.parlamento.gub.uy. Acesso em 15 de setembro de 2007.

CONSTITUCIÓN EsPAÑOLA DE 1978, in www.tribunalconstitucional.es. Acesso em 16 de setembro de 2007. 
Constituição DA REpública dos Estados Unidos do BRAsil DE 1891. Org. Aliomar Baleeiro. Brasília, Senado Federal e Ministério da Ciência e Tecnologia, Centro de Estudos Estratégicos, 2001.

Constituição DA República Federativa do Brasil DE 1967. Org. Temístocles Brandão Cavalcanti, Luiz Navarro de Brito e Aliomar Baleeiro. Brasília, Senado Federal e Ministério da Ciência e Tecnologia, Centro de Estudos Estratégicos, 2001.

Constituição da República Federativa do Brasil De 1988. Vade Mecum Saraiva. $2^{a}$ ed., São Paulo, Saraiva, 2006.

CONSTITUIÇÃO DA REPÚBliCA PORTUGUESA DE 1976, in www.parlamento.pt. Acesso em 3 de janeiro de 2007.

CONSTITUTION FRANÇAISE DE 1958, in www.conseil-constitutionnel.fr. Acesso em 18 de setembro de 2007.

Convenção de Viena sobre o Direito dos Tratados de 1969. Coletânea de direito internacional. Org. Valério de Oliveira Mazzuoli. 4ª ed., São Paulo, RT, 2006. 